\title{
Smoking Prevalence among Physicians: A Systematic Review and Meta-Analysis
}

\author{
Anaïs Besson ${ }^{1,+}{ }^{\dagger}$, Alice Tarpin ${ }^{1,+}$, Valentin Flaudias ${ }^{2}{ }^{\oplus}$, Georges Brousse ${ }^{3}$, Catherine Laporte ${ }^{3}(\mathbb{D}$, \\ Amanda Benson ${ }^{4}\left(\mathbb{D}\right.$, Valentin Navel ${ }^{5}\left(\mathbb{D}\right.$, Jean-Baptiste Bouillon-Minois ${ }^{6, *(1)}$ and Frédéric Dutheil ${ }^{7}(\mathbb{D})$ \\ 1 Family Medicine, University Hospital of Clermont-Ferrand, Université Clermont Auvergne, \\ F-63000 Clermont-Ferrand, France; bessona.ab@gmail.com (A.B.); alice.tarpin@gmail.com (A.T.) \\ 2 Univ Angers, Laboratoire de psychologie des Pays de la Loire, Université de Nantes, LPPL, EA 4638, \\ F-44000 Nantes, France; valentin.flaudias@univ-nantes.fr \\ 3 Clermont Auvergne INP, CHU Clermont-Ferrand, CNRS, Institut Pascal, Université Clermont Auvergne, \\ F-63000 Clermont-Ferrand, France; gbrousse@chu-clermontferrand.fr (G.B.); \\ catherinelaporte63@gmail.com (C.L.) \\ 4 Sport Innovation Research Group, Department of Health and Biostatistics, Swinburne University \\ of Technology, Melbourne, VIC 3122, Australia; abenson@swin.edu.au \\ 5 CNRS, INSERM, GReD, Translational Approach to Epithelial Injury and Repair, CHU Clermont-Ferrand, \\ Ophthalmology, Université Clermont Auvergne, F-63000 Clermont-Ferrand, France; \\ valentin.navel@hotmail.fr \\ 6 CNRS, LaPSCo, Physiological and Psychosocial Stress, University Hospital of Clermont-Ferrand, \\ Emergency Medicine, Université Clermont Auvergne, F-63000 Clermont-Ferrand, France \\ 7 CNRS, LaPSCo, Physiological and Psychosocial Stress, University Hospital of Clermont-Ferrand, \\ Occupational and Environmental Medicine, Université Clermont Auvergne, WittyFit, \\ F-63000 Clermont-Ferrand, France; fdutheil@chu-clermontferrand.fr \\ updates \\ Citation: Besson, A.; Tarpin, A.; \\ Flaudias, V.; Brousse, G.; Laporte, C.; \\ * Correspondence: jbb.bouillon@gmail.com; Tel.: +33-6-74-36-04-23; Fax: +33-4-73-27-46-49 \\ + Contributed equally.
} Benson, A.; Navel, V.; Bouillon-Minois, J.-B.; Dutheil, F. Smoking Prevalence among Physicians: A Systematic Review and Meta-Analysis. Int. J. Environ. Res. Public Health 2021, 18, 13328. https:// doi.org/10.3390/ijerph182413328

Academic Editor: Aziz Rahman

Received: 24 November 2021 Accepted: 15 December 2021 Published: 17 December 2021

Publisher's Note: MDPI stays neutral with regard to jurisdictional claims in published maps and institutional affiliations.

Copyright: (C) 2021 by the authors. Licensee MDPI, Basel, Switzerland. This article is an open access article distributed under the terms and conditions of the Creative Commons Attribution (CC BY) license (https:/ / creativecommons.org/licenses/by/ $4.0 /)$.

\begin{abstract}
Background: Smoking is a major public health problem. Although physicians have a key role in the fight against smoking, some of them are still smoking. Thus, we aimed to conduct a systematic review and meta-analysis on the prevalence of smoking among physicians. Methods: PubMed, Cochrane, and Embase databases were searched. The prevalence of smoking among physicians was estimated and stratified, where possible, by specialties, continents, and periods of time. Then, meta-regressions were performed regarding putative influencing factors such as age and sex. Results: Among 246 studies and 497,081 physicians, the smoking prevalence among physicians was $21 \%$ (95CI 20 to $23 \%$ ). Prevalence of smoking was $25 \%$ in medical students, $24 \%$ in family practitioners, $18 \%$ in surgical specialties, $17 \%$ in psychiatrists, $16 \%$ in medical specialties, $11 \%$ in anesthesiologists, $9 \%$ in radiologists, and $8 \%$ in pediatricians. Physicians in Europe and Asia had a higher smoking prevalence than in Oceania. The smoking prevalence among physicians has decreased over time. Male physicians had a higher smoking prevalence. Age did not influence smoking prevalence. Conclusion: Prevalence of smoking among physicians is high, around $21 \%$. Family practitioners and medical students have the highest percentage of smokers. All physicians should benefit from targeted preventive strategies.
\end{abstract}

Keywords: tobacco; smoking; physician; doctor; prevalence

\section{Introduction}

Smoking is a major public health problem [1]. According to the International Classification of Diseases (ICD-10), tobacco smoking disorder is considered a mental and behavioral disease [2]. Furthermore, according to the World Health Organization, there are about a billion smokers around the world and tobacco kills more than seven million of them per year [1]. Tobacco control has been present in many countries for several years. In 2003, the WHO adopted the Framework Convention on Tobacco Control. Despite their 
knowledge of the health risks linked to smoking [3], some physicians smoke too [4,5]. Prevalence of smoking among physicians can be a public health issue both for themselves and for patients because they play a key role in combating tobacco use [6]. Indeed, it has been demonstrated that physicians who smoke are less likely to promote quitting smoking to their patients $[7,8]$. However, the prevalence of smoking among physicians has not recently been systematically reported in the literature. Moreover, some medical specialties may be particularly at risk of smoking, due to workload [9] or work conditions [10], for example. In addition, a country's culture or wealth can influence the perception of smoking [11,12]. Lastly, the perception of smoking has, historically, changed considerably [13], from a rewarding to a negative image [14]. Although there is a dense literature on the impact of tobacco smoking on health among general population, we did not find any systematic review and meta-analysis on smoking among physicians.

Therefore, we aimed to conduct a systematic review and meta-analysis on the prevalence of smoking among physicians. Secondary objectives were to report physicians' smoking prevalence depending on their specialties, to investigate differences between countries, changes over time and putative effects of sociodemographic factors.

\section{Materials and Methods}

\subsection{Literature Search}

We reviewed all studies reporting the smoking prevalence among physicians. Eligible articles had to appear on the PubMed, Cochrane Library, Embase, and ScienceDirect databases with the following keywords: "smoking" and "physician" (or "doctor") and "prevalence". The search was conducted up to May 2021 (details for the search strategy used within each database are available in Appendix A. Studies could be cross-sectional studies, cohort studies, or clinical trials. The search was not limited to specific years. We limited our search to English or French articles. To be included, studies needed to describe our primary outcome variable, i.e., the prevalence of smoking among physicians. Two authors (Anaïs Besson and Alice Tarpin) conducted the literature searches, reviewed the abstracts, and, based on the selection criteria, decided the suitability of the articles for inclusion and extracted the data. When necessary, disagreements were solved with a third author (Frédéric Dutheil). We followed the Preferred Reporting Items for Systematic Reviews and Meta-Analyses (PRISMA) guidelines [15].

\subsection{Data Extraction}

The primary outcome analyzed was the smoking prevalence and type of smoking (occasional or regular) among physicians. Secondary outcomes reported medical specialty, continent, study's period, ex-smoking prevalence, sociodemographic parameters (age, gender, family status, and workplace setting), workload (mean duration week), clinical parameters (body mass index and physical activity behavior), and smoking prevalence among a population control.

\subsection{Quality of Assessment}

We used the Newcastle-Ottawa Scale (NOS) to check the quality of included articles [16]. The maximum score was nine for cohort and ten for cross-sectional studies. Additionally, we also used the Strengthening the Reporting of Observational Studies in Epidemiology (STROBE) for cohort and cross-sectional studies [17], and the Consolidated Standards of Reporting Trials (CONSORT) for randomized studies [18] (Appendix B).

\subsection{Statistical Considerations}

Statistical analysis was conducted using Stata software (v16, StataCorp, College Station, TX, USA). Extracted data were summarized for each study and reported as mean (standard deviation) and count (\%) for continuous and categorical variables, respectively. Prevalence of smokers and 95\% confidence intervals were estimated using random-effects models assuming between and within study variability (DerSimonian and Laird approach) [19]. 
Then, we stratified results depending on specialties, continents, and periods of time. Statistical heterogeneity between studies was assessed using forest plots, confidence intervals, and $\mathrm{I}^{2}$. The $\mathrm{I}^{2}$ statistic is the most common metric to measure heterogeneity and is easily interpretable: heterogeneity is considered low for $\mathrm{I}^{2}<25 \%$, modest for $25-50 \%$, and high for $>50 \%$ [20]. We aimed to conduct a sensitivity analysis by excluding studies not evenly distributed around the base of the metafunnel. We also proposed meta-regressions to investigate putative factors influencing the prevalence of smoking in physicians, such as sociodemographic (age, sex), specialties, continents, and periods of time. Results were expressed as regression coefficients and $95 \%$ confidence intervals. Type I-error was fixed at $\alpha=0.05$.

\section{Results}

An initial search produced 3112 possible articles. Removal of duplicates and use of the selection criteria reduced the number of articles reporting the smoking prevalence among physicians to 246 articles (Figure 1). Main characteristics of the studies are presented in Table 1.

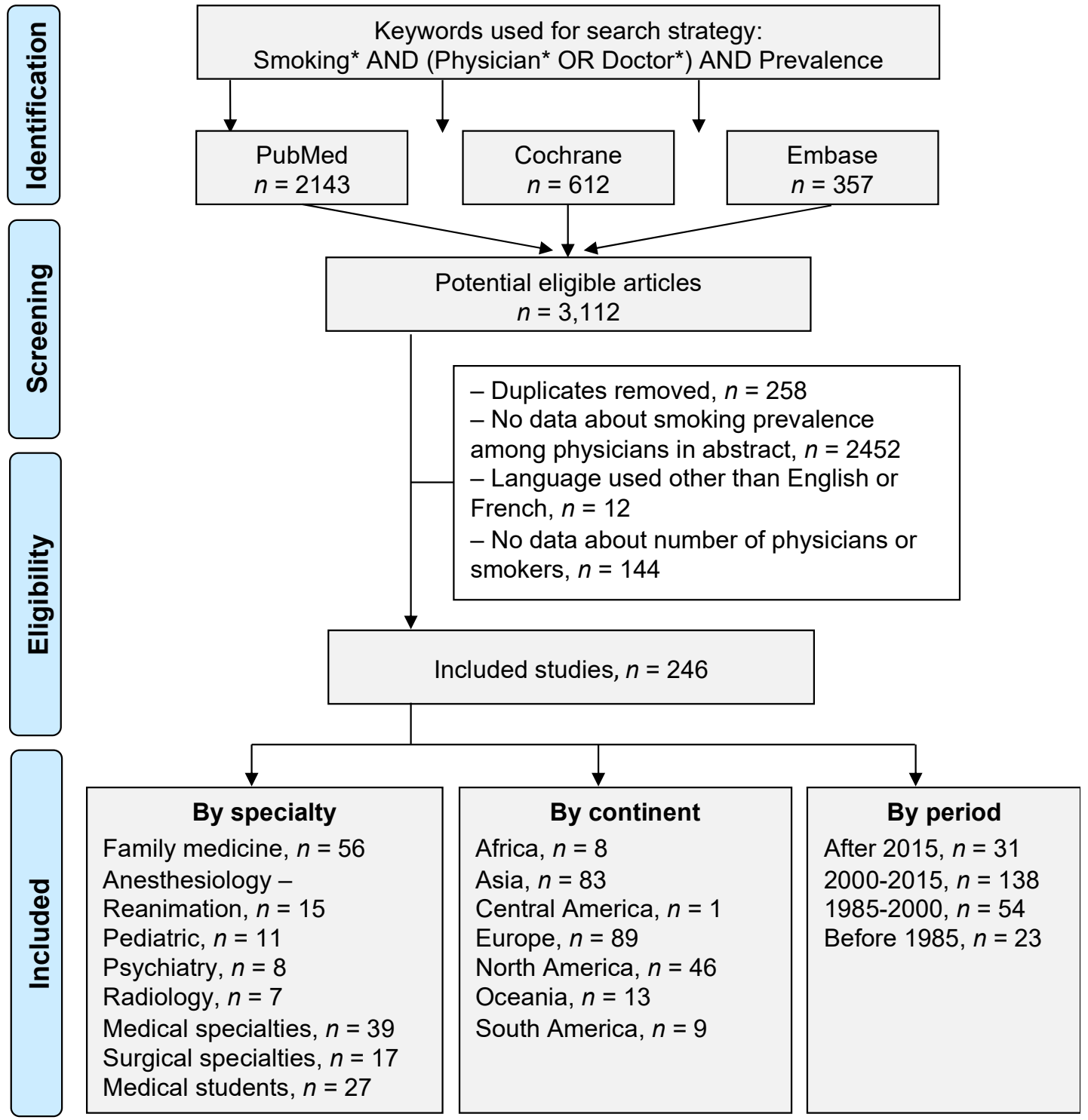

Figure 1. Flow chart. Three databases were asked (PubMed, Cochrane, and Embase). Over 3112 eligible articles, 246 were included. Stratification was performed by specialty, by continent, and by time period. *: details for the search strategy used within each database are available in Appendix A. 
Table 1. Characteristics of included studies.

\begin{tabular}{|c|c|c|c|c|c|c|c|c|c|c|c|c|}
\hline \multirow[b]{2}{*}{ Study } & \multirow[b]{2}{*}{ Country } & \multirow[b]{2}{*}{$\begin{array}{c}\text { GDP per } \\
\text { Capital }\end{array}$} & \multirow[b]{2}{*}{$\begin{array}{l}\text { Period of } \\
\text { Data } \\
\text { Collection }\end{array}$} & \multicolumn{4}{|c|}{ Physicians } & \multirow{2}{*}{$\begin{array}{c}\text { Prevalence } \\
\text { Regular } \\
\text { Smokers }\end{array}$} & \multirow{2}{*}{\begin{tabular}{c|}
$(\%)$ of \\
$\begin{array}{c}\text { Occasional } \\
\text { Smokers }\end{array}$
\end{tabular}} & \multicolumn{2}{|l|}{ Smokers } & \multirow[b]{2}{*}{$\begin{array}{c}\text { \% Men } \\
\text { among } \\
\text { Smokers }\end{array}$} \\
\hline & & & & $n$ & $\begin{array}{c}\% \\
\text { Men }\end{array}$ & Age & Speciality & & & $\begin{array}{c}\text { Former } \\
\text { Smokers }\end{array}$ & $\begin{array}{c}\text { Total } \\
\text { (Regular \& } \\
\text { Occasional) }\end{array}$ & \\
\hline Aaro 1977 & Norway & 6812 & 1952-1974 & 3544 & & & Not defined & & & & 58.3 & 92.5 \\
\hline $\begin{array}{l}\text { Abdullah } \\
2006\end{array}$ & China & 1149 & 2002 & 757 & 78.2 & & Not defined & & & 2.1 & 4.3 & \\
\hline $\begin{array}{l}\text { Aboyans } \\
2009\end{array}$ & France & 41,508 & 2007 & 371 & & 49.8 & Cardiology & & & 32.4 & 8.1 & \\
\hline $\begin{array}{l}\text { Akvardar } \\
2004\end{array}$ & Turkey & 6041 & & 319 & & & Study, Others & & & & 37.6 & \\
\hline $\begin{array}{l}\text { Al Alwan } \\
2013\end{array}$ & Saudi Arabia & 16,094 & 2009 & 100 & & & Not defined & & & 7 & 12 & \\
\hline $\begin{array}{l}\text { Alarjan } \\
2015\end{array}$ & Jordan & 4096 & & 162 & & & Not defined & & & & 34.0 & \\
\hline $\begin{array}{l}\text { Al-Khateeb } \\
1990\end{array}$ & Bahrain & 7959 & 1988 & 301 & & & Not defined & & & 8.6 & 60.1 & \\
\hline $\begin{array}{l}\text { Al-Lawati } \\
2009\end{array}$ & Oman & 16,784 & & 1079 & & & $\begin{array}{l}\text { Family medicine, } \\
\text { Biology, Others }\end{array}$ & & & & 22.2 & 97.5 \\
\hline Allan 1976 & Australia & 7475 & & 1153 & & & $\begin{array}{c}\text { Family medicine, } \\
\text { Radiology, Pathology, } \\
\text { Anesthesiology- } \\
\text { Reanimation, } \\
\text { Gynecology, Others }\end{array}$ & & & & 14 & \\
\hline $\begin{array}{l}\text { Al Shahrani } \\
2021\end{array}$ & Saudi Arabia & 23,338 & 2018 & 290 & 59.7 & & Not defined & & & & 34.8 & 70.3 \\
\hline Amara 2008 & Morocco & 2885 & 2007 & 75 & & 44.4 & Pneumology & 37.5 & 62.5 & 12 & 10,7 & \\
\hline Amte 2015 & India & 1606 & & 242 & 84.7 & 37.9 & Not defined & 36.4 & 63.6 & & 13.6 & \\
\hline An 2004 & USA & 36,334 & 2000 & 750 & 68.9 & & Not defined & & & 16.9 & 1.5 & \\
\hline Arnetz 1988 & Sweden & 24,189 & & 66 & 100 & $43.9-46.8$ & Family medicine, Others & & & $23.3-33.3$ & 22.7 & 100 \\
\hline
\end{tabular}


Table 1. Cont.

\begin{tabular}{|c|c|c|c|c|c|c|c|c|c|c|c|c|}
\hline \multirow[b]{2}{*}{ Study } & \multirow[b]{2}{*}{ Country } & \multirow[b]{2}{*}{$\begin{array}{c}\text { GDP per } \\
\text { Capital }\end{array}$} & \multirow[b]{2}{*}{$\begin{array}{l}\text { Period of } \\
\text { Data } \\
\text { Collection }\end{array}$} & \multicolumn{4}{|c|}{ Physicians } & \multirow{2}{*}{$\begin{array}{c}\text { Prevalence } \\
\text { Regular } \\
\text { Smokers }\end{array}$} & \multirow{2}{*}{$\begin{array}{c}\mathbf{( \% )} \text { of } \\
\begin{array}{c}\text { Occasional } \\
\text { Smokers }\end{array}\end{array}$} & \multicolumn{2}{|l|}{ Smokers } & \multirow[b]{2}{*}{$\begin{array}{l}\text { \% Men } \\
\text { among } \\
\text { Smokers }\end{array}$} \\
\hline & & & & $n$ & $\begin{array}{c}\% \\
\text { Men }\end{array}$ & Age & Speciality & & & $\begin{array}{l}\text { Former } \\
\text { Smokers }\end{array}$ & $\begin{array}{c}\text { Total } \\
\text { (Regular \& } \\
\text { Occasional) }\end{array}$ & \\
\hline $\begin{array}{c}\text { Aryayev } \\
2014\end{array}$ & Ukraine & 3105 & & 150 & 31.3 & & $\begin{array}{l}\text { Family medicine, } \\
\text { Paediatry, Study }\end{array}$ & & & & 42 & 61.9 \\
\hline Baltaci 2014 & Turkey & 10,672 & 2010-2011 & 1233 & 57.1 & 38.94 & Not defined & & & 14.8 & 34.1 & \\
\hline $\begin{array}{l}\text { Baptista } \\
1993\end{array}$ & Venezuela & 2368 & 1990 & 191 & 49.7 & 31 & Not defined & & & & 20.9 & \\
\hline $\begin{array}{l}\text { Barengo } \\
2004\end{array}$ & Finland & & 1990-2001 & 4546 & 51.4 & & Not defined & 38.1 & 61.9 & & 16 & \\
\hline $\begin{array}{l}\text { Barengo } \\
2005\end{array}$ & Finland & 24,913 & 2001 & 707 & & & Family medicine & & & & 12.7 & \\
\hline $\begin{array}{c}\text { Barnoya } \\
2002\end{array}$ & Guatemela & 1702 & 2002 & 174 & 56.9 & & Not defined & & & 35 & 17.8 & 56.9 \\
\hline $\begin{array}{c}\text { Basnyat } \\
2000\end{array}$ & UK & 28,015 & 1998 & 314 & 97.8 & 51 & Not defined & & & 37 & 10.2 & 97.8 \\
\hline Basu 2011 & India & 1346 & 2010 & 182 & & & Study & 85.5 & 14.5 & & 30.2 & \\
\hline $\begin{array}{l}\text { Behbehani } \\
2004\end{array}$ & Bahrain, Kuwait & & 2000-2001 & 1440 & 66.5 & $44.6-44.7$ & Not defined & 62.1 & 37.9 & $14.3-15.9$ & 17.2 & 92.7 \\
\hline Belkić 2007 & Serbie & 2150 & 2002-2004 & 112 & 0 & 48.9 & Not defined & & & 12.5 & 31.3 & 0 \\
\hline Belkić 2012 & Serbie & 2150 & 2002-2004 & 191 & 42.9 & & Not defined & & & & 30.4 & 39.7 \\
\hline Bener 1993 & $\begin{array}{l}\text { Kuwait, United } \\
\text { Arab Emirates }\end{array}$ & & 1990-1992 & 527 & & & Not defined & & & $12.7-13.5$ & 37 & \\
\hline $\begin{array}{l}\text { Borgan } \\
2014\end{array}$ & Bahrain & 24,737 & 2013 & 148 & 33.8 & 45 & Not defined & & & 3.9 & 10.1 & 80 \\
\hline Bortz 1992 & USA & 25,493 & & 126 & 77.8 & & Not defined & & & 22.2 & 1.6 & 100 \\
\hline Bostan 2015 & Turkey & 10,672 & 2010-2011 & 699 & & 38.7 & Pneumology & & & 19.5 & 9.9 & \\
\hline $\begin{array}{l}\text { Bourke } \\
1972\end{array}$ & Ireland & 1152 & 1967-1969 & 1580 & 86 & & Not defined & & & $23.6-42.5$ & 45.4 & 91.8 \\
\hline
\end{tabular}


Table 1. Cont.

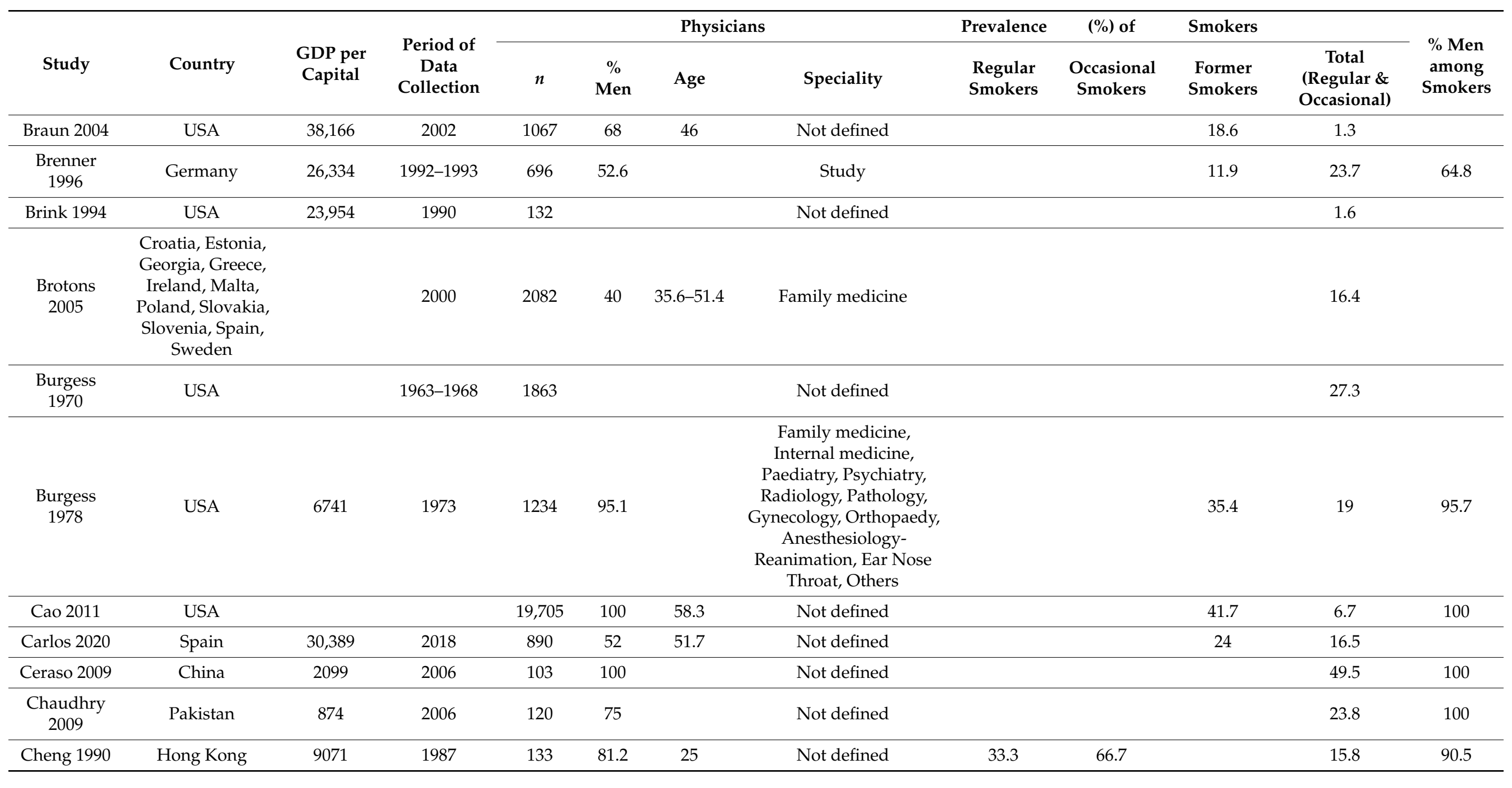


Table 1. Cont.

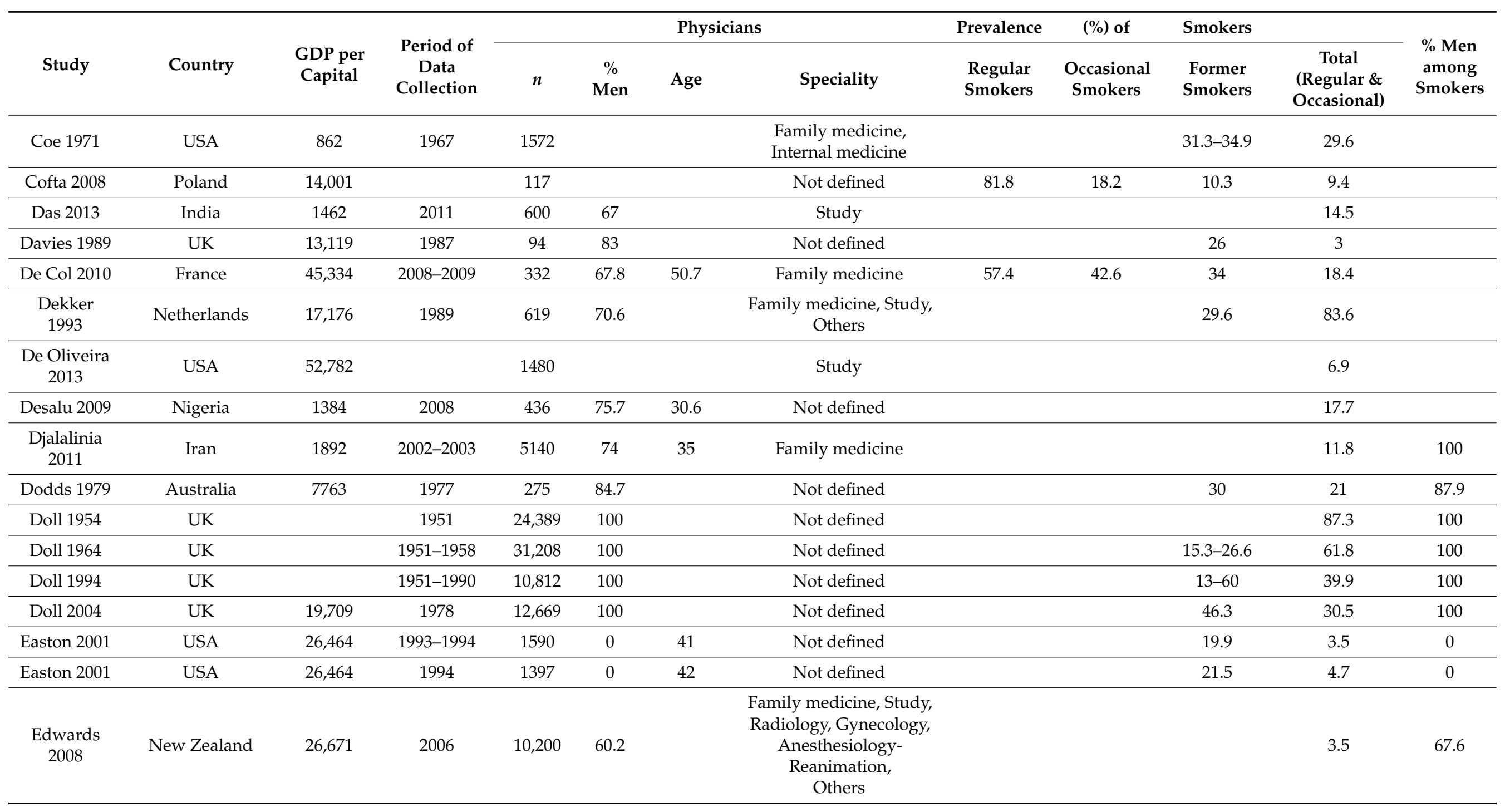


Table 1. Cont.

\begin{tabular}{|c|c|c|c|c|c|c|c|c|c|c|c|c|}
\hline \multirow[b]{2}{*}{ Study } & \multirow[b]{2}{*}{ Country } & \multirow[b]{2}{*}{$\begin{array}{l}\text { GDP per } \\
\text { Capital }\end{array}$} & \multirow[b]{2}{*}{$\begin{array}{l}\text { Period of } \\
\text { Data } \\
\text { Collection }\end{array}$} & \multicolumn{4}{|c|}{ Physicians } & \multirow{2}{*}{$\begin{array}{c}\text { Prevalence } \\
\text { Regular } \\
\text { Smokers }\end{array}$} & \multirow{2}{*}{$\begin{array}{c}\mathbf{( \% )} \text { of } \\
\begin{array}{c}\text { Occasional } \\
\text { Smokers }\end{array}\end{array}$} & \multicolumn{2}{|l|}{ Smokers } & \multirow{2}{*}{$\begin{array}{l}\text { \% Men } \\
\text { among } \\
\text { Smokers }\end{array}$} \\
\hline & & & & $n$ & $\begin{array}{c}\% \\
\text { Men }\end{array}$ & Age & Speciality & & & $\begin{array}{c}\text { Former } \\
\text { Smokers }\end{array}$ & $\begin{array}{c}\text { Total } \\
\text { (Regular \& } \\
\text { Occasional) }\end{array}$ & \\
\hline $\begin{array}{c}\text { Edwards } \\
2018\end{array}$ & New Zealand & 42,949 & 2013 & 12,684 & 55.7 & & $\begin{array}{c}\text { Family medicine, Study, } \\
\text { Radiology, Gynecology, } \\
\text { Anesthesiology- } \\
\text { Reanimation, } \\
\text { Others }\end{array}$ & & & 12.1 & 2.1 & 61.6 \\
\hline Fadhil 2007 & Bahrain & 17,959 & 2005 & 120 & 35.8 & 36.5 & Family medicine & & & 10 & 24.2 & \\
\hline $\begin{array}{c}\text { Fanello } \\
1990\end{array}$ & France & & 1973-1987 & 2718 & & & Family medicine & & & & 44.6 & \\
\hline Fathi 2016 & Iran & 7833 & 2012-2013 & 225 & & & Not defined & & & & 21.3 & \\
\hline Fowler 1989 & UK & 15,987 & 1988 & 3240 & 77 & & Family medicine & & & 33 & 13.5 & \\
\hline $\begin{array}{c}\text { Franceschi } \\
1986\end{array}$ & Italy & 7964 & 1985 & 709 & & & $\begin{array}{c}\text { Family medicine, } \\
\text { Internal medicine, Public } \\
\text { health, Others }\end{array}$ & & & $14-26$ & 31.3 & \\
\hline Frank 1998 & USA & 27,777 & 1994 & 4501 & 0 & 42.2 & Not defined & & & 18.6 & 3.7 & 0 \\
\hline Frank 2009 & Canada & 44,545 & 2007-2008 & 3213 & 66 & & Not defined & 57.1 & 42.9 & & 14 & \\
\hline Freour 2011 & France & 41,575 & 2009 & 337 & & & Not defined & & & 30.6 & 12.5 & \\
\hline $\begin{array}{c}\text { Garfinkel } \\
1976\end{array}$ & USA & & 1959-1972 & 8503 & & & Not defined & & & & 32.7 & \\
\hline Glavas 2003 & Greece & 18,478 & & 119 & 76.5 & & Not defined & & & & 37 & \\
\hline $\begin{array}{c}\text { Grossman } \\
1999\end{array}$ & Costa Rica & 2828 & 1993-1994 & 216 & 70.8 & 41 & Not defined & & & 40 & 19.4 & 61.9 \\
\hline Gunes 2005 & Turkey & 3660 & 2002 & 257 & 77.8 & 31.3 & Not defined & 81.3 & 18.8 & & 37.4 & \\
\hline Gupta 2013 & USA & 47,100 & 2009 & 177 & 41.2 & & $\begin{array}{l}\text { Internal medicine, } \\
\text { Paediatry, Others, } \\
\text { Emergency }\end{array}$ & 99.6 & 0.4 & & 0.6 & \\
\hline Hallett 1983 & UK & & 1980 & 385 & & & Family medicine & & & 44.4 & 27.8 & \\
\hline
\end{tabular}


Table 1. Cont.

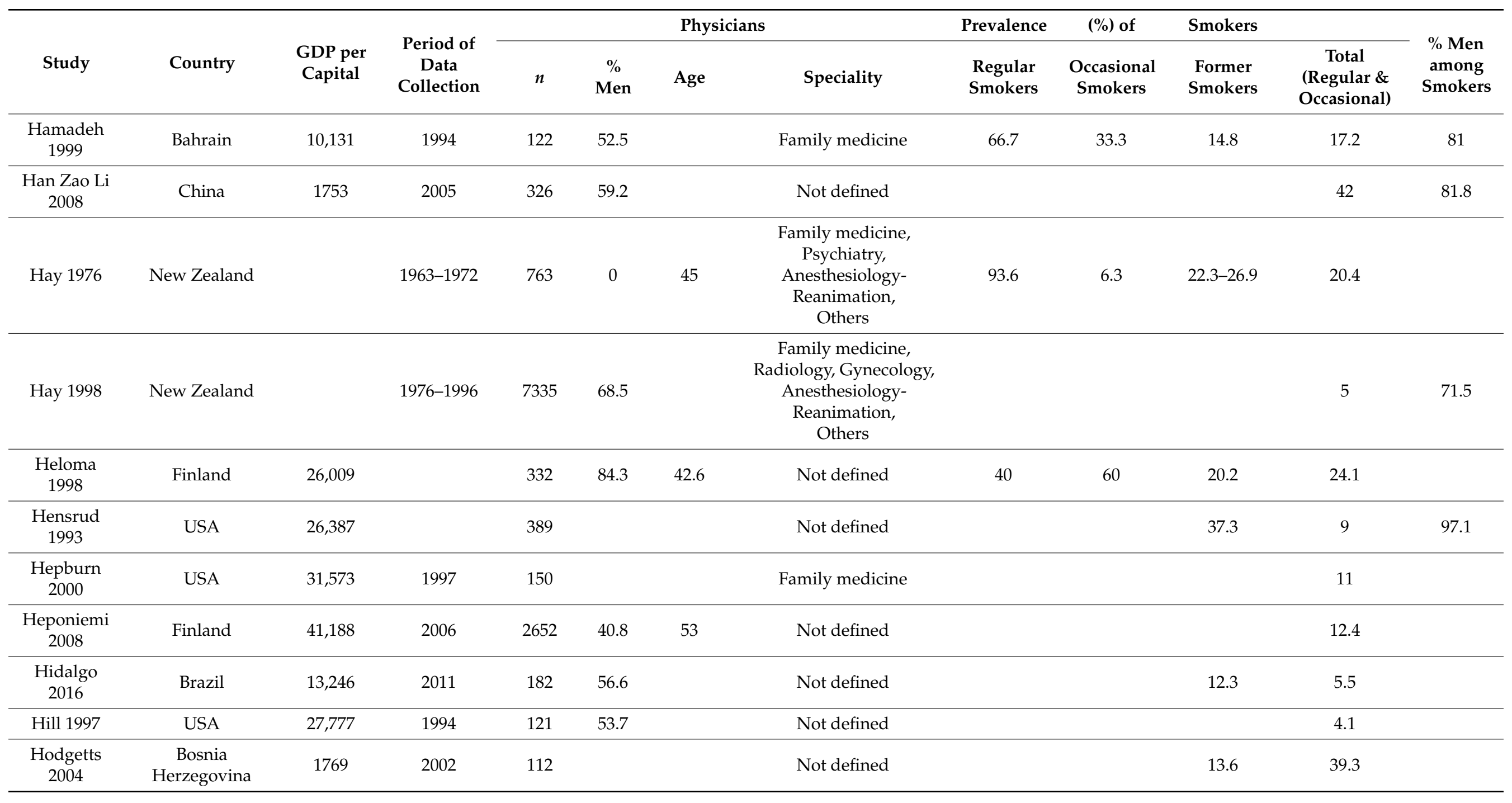


Table 1. Cont.

\begin{tabular}{|c|c|c|c|c|c|c|c|c|c|c|c|c|}
\hline \multirow[b]{2}{*}{ Study } & \multirow[b]{2}{*}{ Country } & \multirow[b]{2}{*}{$\begin{array}{l}\text { GDP per } \\
\text { Capital }\end{array}$} & \multirow{2}{*}{$\begin{array}{l}\text { Period of } \\
\text { Data } \\
\text { Collection }\end{array}$} & \multicolumn{4}{|c|}{ Physicians } & \multirow{2}{*}{$\begin{array}{c}\text { Prevalence } \\
\text { Regular } \\
\text { Smokers }\end{array}$} & \multirow{2}{*}{$\begin{array}{c}\mathbf{( \% )} \text { of } \\
\begin{array}{c}\text { Occasional } \\
\text { Smokers }\end{array}\end{array}$} & \multicolumn{2}{|l|}{ Smokers } & \multirow{2}{*}{$\begin{array}{c}\text { \% Men } \\
\text { among } \\
\text { Smokers }\end{array}$} \\
\hline & & & & $n$ & $\begin{array}{c}\% \\
\text { Men }\end{array}$ & Age & Speciality & & & $\begin{array}{c}\text { Former } \\
\text { Smokers }\end{array}$ & $\begin{array}{c}\text { Total } \\
\text { (Regular \& } \\
\text { Occasional) }\end{array}$ & \\
\hline $\begin{array}{l}\text { Hoseainrezae } \\
2013\end{array}$ & Iran & 6111 & & 252 & & & Not defined & & & 7.1 & 9.5 & \\
\hline Huang 2013 & China & 5618 & 2011 & 720 & 100 & & Not defined & 60 & 40 & & 25.7 & 100 \\
\hline $\begin{array}{c}\text { Hughes } \\
1991\end{array}$ & USA & 20,039 & 1987 & 1733 & 69.4 & 30 & Not defined & & & & 5.3 & \\
\hline $\begin{array}{c}\text { Hughes } \\
1992\end{array}$ & USA & 22,857 & 1989-1990 & 5426 & 82.4 & & Not defined & & & & 3.9 & \\
\hline $\begin{array}{c}\text { Hughes } \\
1999\end{array}$ & USA & 22,857 & 1989-1990 & 5418 & & & $\begin{array}{l}\text { Family medicine, } \\
\text { Internal medicine, } \\
\text { Emergency, Pathology, } \\
\text { Paediatry, Psychiatry, } \\
\text { Anesthesiology- } \\
\text { Reanimation, } \\
\text { Gynecology, Others }\end{array}$ & & & & 14.3 & \\
\hline Hung 2013 & USA & 48,467 & 2010 & 1000 & 68.5 & 45.3 & Family medicine & & & & 4 & \\
\hline $\begin{array}{c}\text { Hussain } \\
1993\end{array}$ & UK & 19,901 & 1991 & 1069 & & & Not defined & & & & 5 & \\
\hline Içli 1992 & Turkey & 2736 & 1991 & 200 & & & Study & & & & 34 & \\
\hline Innos 2002 & Estonia & & 1982 & 3673 & 23.7 & & Not defined & & & 13.1 & 21.3 & 45.6 \\
\hline $\begin{array}{c}\text { Jacot } \\
\text { Sadowski } \\
2009\end{array}$ & Swiss & 41,376 & 2002 & 1856 & 78.8 & & Not defined & 40.8 & 59.2 & & 17.6 & \\
\hline Jiang 2007 & China & 1509 & 2004 & 3552 & 55.1 & & Not defined & & & 2.7 & 22.9 & 98 \\
\hline $\begin{array}{l}\text { Jiménez- } \\
\text { Ruiz } \\
2015\end{array}$ & Spain & 29,462 & 2014 & 416 & 59.4 & & Not defined & 80.4 & 19.6 & 38 & 11.1 & \\
\hline Jingi 2015 & Cameroon & 1381 & 2012 & 65 & 69.2 & 39.1 & Family medicine & & & & 12.3 & 100 \\
\hline
\end{tabular}


Table 1. Cont.

\begin{tabular}{|c|c|c|c|c|c|c|c|c|c|c|c|c|}
\hline \multirow[b]{2}{*}{ Study } & \multirow[b]{2}{*}{ Country } & \multirow[b]{2}{*}{$\begin{array}{l}\text { GDP per } \\
\text { Capital }\end{array}$} & \multirow[b]{2}{*}{$\begin{array}{l}\text { Period of } \\
\text { Data } \\
\text { Collection }\end{array}$} & \multicolumn{4}{|c|}{ Physicians } & \multirow{2}{*}{$\begin{array}{c}\text { Prevalence } \\
\text { Regular } \\
\text { Smokers }\end{array}$} & \multirow{2}{*}{$\begin{array}{c}\mathbf{( \% )} \text { of } \\
\begin{array}{c}\text { Occasional } \\
\text { Smokers }\end{array}\end{array}$} & \multicolumn{2}{|l|}{ Smokers } & \multirow[b]{2}{*}{$\begin{array}{c}\text { \% Men } \\
\text { among } \\
\text { Smokers }\end{array}$} \\
\hline & & & & $n$ & $\begin{array}{c}\% \\
\text { Men }\end{array}$ & Age & Speciality & & & $\begin{array}{l}\text { Former } \\
\text { Smokers }\end{array}$ & $\begin{array}{c}\text { Total } \\
\text { (Regular \& } \\
\text { Occasional) }\end{array}$ & \\
\hline John 2003 & Germany & & 1989-1999 & 2509 & & & Not defined & & & $18.9-22.5$ & 20.4 & \\
\hline $\begin{array}{c}\text { Joossens } \\
1987\end{array}$ & Belgium & 8846 & 1983 & 2157 & & & Not defined & & & 33 & 32 & \\
\hline $\begin{array}{l}\text { Josseran } \\
2000\end{array}$ & $\begin{array}{c}\text { France, } \\
\text { Netherlands, } \\
\text { Spain, UK, } \\
\text { Greece, Brazil }\end{array}$ & & 1992-1997 & 16,788 & & & $\begin{array}{l}\text { Family medicine, Study, } \\
\text { Others }\end{array}$ & & & & 9.5 & \\
\hline $\begin{array}{l}\text { Josseran } \\
2005\end{array}$ & France & 24,974 & 1998 & 2073 & 79.3 & 45.1 & Family medicine & & & 45.5 & 32.1 & 83.6 \\
\hline Julião 2013 & Brazil & 8598 & 2009 & 515 & 66.8 & 45.3 & Not defined & & & 23.3 & 5.8 & \\
\hline Kaetsu 2002 & Japan & & $1983-1990$ & 5312 & 95.7 & & Not defined & & & & 36.6 & 99.3 \\
\hline Kaetsu 2002 & Japan & 10,425 & 1983 & 4190 & 95.6 & & Not defined & & & & 41.9 & 99 \\
\hline $\begin{array}{c}\text { Kaneita } \\
2010\end{array}$ & Japan & & 2000-2008 & 10,890 & 66.4 & & Not defined & & & & 16.1 & 88.2 \\
\hline $\begin{array}{l}\text { Kawahara } \\
2000\end{array}$ & Japan & 38,437 & 1996-1997 & 709 & 91.8 & 54.7 & Not defined & & & 46.3 & 26 & 98.4 \\
\hline $\begin{array}{l}\text { Kawakami } \\
1997\end{array}$ & Japan & 39,269 & 1994 & 323 & 84.8 & 59.8 & Not defined & & & 46.1 & 21.1 & 95.6 \\
\hline $\begin{array}{c}\text { Kawane } \\
1993\end{array}$ & Japan & 24,813 & 1989 & 6224 & & & Pneumology & & & 39.4 & 24.8 & \\
\hline Kono 1985 & Japan & 920 & 1965 & 5446 & 100 & & Not defined & & & & 67.8 & \\
\hline Kotz 2007 & Netherlands & 29,204 & 2002-2003 & 1180 & & $45.9-48.3$ & $\begin{array}{c}\text { Family medicine, } \\
\text { Cardiology, Pneumology }\end{array}$ & & & $24.8-29.7$ & 6.6 & \\
\hline
\end{tabular}


Table 1. Cont.

\begin{tabular}{|c|c|c|c|c|c|c|c|c|c|c|c|c|}
\hline \multirow[b]{2}{*}{ Study } & \multirow[b]{2}{*}{ Country } & \multirow[b]{2}{*}{$\begin{array}{l}\text { GDP per } \\
\text { Capital }\end{array}$} & \multirow[b]{2}{*}{$\begin{array}{l}\text { Period of } \\
\text { Data } \\
\text { Collection }\end{array}$} & \multicolumn{4}{|c|}{ Physicians } & \multirow{2}{*}{$\begin{array}{c}\text { Prevalence } \\
\text { Regular } \\
\text { Smokers }\end{array}$} & \multirow{2}{*}{$\begin{array}{c}\mathbf{( \% )} \text { of } \\
\begin{array}{c}\text { Occasional } \\
\text { Smokers }\end{array}\end{array}$} & \multicolumn{2}{|l|}{ Smokers } & \multirow[b]{2}{*}{$\begin{array}{l}\text { \% Men } \\
\text { among } \\
\text { Smokers }\end{array}$} \\
\hline & & & & $n$ & $\begin{array}{c}\% \\
\text { Men }\end{array}$ & Age & Speciality & & & $\begin{array}{c}\text { Former } \\
\text { Smokers }\end{array}$ & $\begin{array}{c}\text { Total } \\
\text { (Regular \& } \\
\text { Occasional) }\end{array}$ & \\
\hline Lam 2011 & China & 2099 & 2006 & 504 & 100 & & Not defined & & & & 46.2 & 100 \\
\hline $\begin{array}{l}\text { La Vecchia } \\
2000\end{array}$ & Italy & 21,998 & 1999 & 501 & 76.6 & 45 & Not defined & 87.7 & 12.3 & 26.5 & 27.5 & \\
\hline Lefcoe 1970 & UK & 2348 & & 310 & 100 & 45.7 & Not defined & & & 19.7 & 51.9 & 100 \\
\hline $\begin{array}{l}\text { Legnini } \\
1987\end{array}$ & USA & 18,237 & 1985 & 266 & & & $\begin{array}{c}\text { Public health, Internal } \\
\text { medicine, Psychiatry, } \\
\text { Others }\end{array}$ & & & $17.1-37$ & 21.1 & \\
\hline $\begin{array}{l}\text { Lindfors } \\
2009\end{array}$ & Finland & 37,703 & 2004 & 328 & 53.4 & 47 & $\begin{array}{l}\text { Anesthesiology- } \\
\text { Reanimation }\end{array}$ & & & & 16.5 & \\
\hline Linn 1986 & USA & 17,134 & 1984 & 211 & 91 & & Not defined & & & & 4 & \\
\hline Lipp 1972 & USA & 5234 & 1970 & 1061 & & & Study & & & & 17 & \\
\hline Magee 2017 & Georgia & 4739 & 2014 & 86 & & & Not defined & & & 14 & 18.6 & \\
\hline Malik 2010 & Pakistan & 1007 & 2009 & 234 & 69.7 & & Not defined & & & & 37.2 & 94.3 \\
\hline $\begin{array}{c}\text { Manson } \\
2000 \\
\end{array}$ & USA & 14,434 & 1982 & 21,068 & 100 & & Not defined & & & 39.2 & 11 & 100 \\
\hline $\begin{array}{l}\text { Mappin- } \\
\text { Kasirer } \\
2020\end{array}$ & UK & & 1951-2016 & 29,737 & 100 & & Not defined & & & $14.9-68.4$ & $8.4-67.2$ & 100 \\
\hline $\begin{array}{c}\text { Marakoğlu } \\
2006\end{array}$ & Turkey & 8035 & & 363 & 69.1 & 34.2 & Not defined & & & 9.9 & 28.7 & 85.6 \\
\hline Márk 1998 & Hungary & 4495 & 1995 & 170 & 62.9 & & Not defined & & & & 25.9 & \\
\hline $\begin{array}{l}\text { Mathavan } \\
2009\end{array}$ & India & 1102 & & 1433 & 65.7 & & Not defined & 66.5 & 33.5 & & 11.9 & 100 \\
\hline $\begin{array}{l}\text { McAuliffe } \\
1984\end{array}$ & USA & 14,439 & 1982 & 134 & & & Not defined & & & & 6 & \\
\hline
\end{tabular}


Table 1. Cont.

\begin{tabular}{|c|c|c|c|c|c|c|c|c|c|c|c|c|}
\hline \multirow[b]{2}{*}{ Study } & \multirow[b]{2}{*}{ Country } & \multirow[b]{2}{*}{$\begin{array}{l}\text { GDP per } \\
\text { Capital }\end{array}$} & \multirow[b]{2}{*}{$\begin{array}{l}\text { Period of } \\
\text { Data } \\
\text { Collection }\end{array}$} & \multicolumn{4}{|c|}{ Physicians } & \multirow{2}{*}{$\begin{array}{l}\text { Prevalence } \\
\text { Regular } \\
\text { Smokers }\end{array}$} & \multirow{2}{*}{$\begin{array}{c}\text { (\%) of } \\
\begin{array}{c}\text { Occasional } \\
\text { Smokers }\end{array}\end{array}$} & \multicolumn{2}{|l|}{ Smokers } & \multirow[b]{2}{*}{$\begin{array}{l}\text { \% Men } \\
\text { among } \\
\text { Smokers }\end{array}$} \\
\hline & & & & $n$ & $\begin{array}{c}\% \\
\text { Men }\end{array}$ & Age & Speciality & & & $\begin{array}{l}\text { Former } \\
\text { Smokers }\end{array}$ & $\begin{array}{c}\text { Total } \\
\text { (Regular \& } \\
\text { Occasional) }\end{array}$ & \\
\hline $\begin{array}{l}\text { McEwen } \\
2001\end{array}$ & UK & 28,383 & 1999 & 303 & 68 & & Family medicine & & & & 4 & \\
\hline $\begin{array}{l}\text { McGrady } \\
2007\end{array}$ & Ireland & 47,631 & 2004 & 650 & & 46.1 & Family medicine & & & 15.2 & 4.2 & \\
\hline Mejia 2011 & Argentina & 5110 & 2005 & 235 & 54.5 & 45 & Gynecology & & & 26.3 & 35.3 & \\
\hline Merrill 2006 & Jordan & 2548 & 2006 & 251 & 69.3 & 45.3 & Not defined & 63 & 37 & 17.5 & 18.3 & 84.8 \\
\hline $\begin{array}{l}\text { Meshefedjian } \\
\quad 2010\end{array}$ & Canada & & 2000-2004 & 610 & 55.1 & & Family medicine & & & 32 & 7.4 & 51.1 \\
\hline $\begin{array}{l}\text { Mikalauskas } \\
2012\end{array}$ & Lithuania & 11,837 & 2009 & 59 & & $43.8-44.4$ & $\begin{array}{l}\text { Anesthesiology- } \\
\text { Reanimation, } \\
\text { Others }\end{array}$ & & & & 13.6 & \\
\hline Misra 2004 & USA & 32,854 & 1998-2000 & 254 & & 50.88 & Not defined & & & & 3.5 & \\
\hline $\begin{array}{c}\text { Mohan } \\
2006\end{array}$ & India & 547 & 2003 & 229 & 66.4 & 42.7 & Not defined & & & 14.4 & 8.7 & 100 \\
\hline $\begin{array}{l}\text { Mohseni- } \\
\text { Bandpei } \\
2011\end{array}$ & Iran & 5630 & 2008 & 223 & 48.4 & 42.7 & Not defined & & & & 13.5 & \\
\hline $\begin{array}{l}\text { Moreno } \\
2006\end{array}$ & Spain & 21,463 & 2003 & 147 & & $21.5-39.1$ & Study, Others & & & $7.3-26.7$ & 47.6 & \\
\hline $\begin{array}{c}\text { Mostafa } \\
2017\end{array}$ & Egypt & 3525 & 2016 & 521 & 64.3 & & $\begin{array}{l}\text { Internal medicine, } \\
\text { Dermatology, Paediatry, } \\
\text { Gynecology, Others }\end{array}$ & & & 8.3 & 21.5 & 89.3 \\
\hline $\begin{array}{l}\text { Movsisyan } \\
2019\end{array}$ & Armenia & 3607 & 2015 & 36 & 25 & & Study & & & 0 & 16.7 & 100 \\
\hline
\end{tabular}


Table 1. Cont.

\begin{tabular}{|c|c|c|c|c|c|c|c|c|c|c|c|c|}
\hline \multirow[b]{2}{*}{ Study } & \multirow[b]{2}{*}{ Country } & \multirow[b]{2}{*}{$\begin{array}{l}\text { GDP per } \\
\text { Capital }\end{array}$} & \multirow[b]{2}{*}{$\begin{array}{l}\text { Period of } \\
\text { Data } \\
\text { Collection }\end{array}$} & \multicolumn{4}{|c|}{ Physicians } & \multirow{2}{*}{$\begin{array}{c}\text { Prevalence } \\
\text { Regular } \\
\text { Smokers }\end{array}$} & \multirow{2}{*}{$\begin{array}{c}(\%) \text { of } \\
\begin{array}{c}\text { Occasional } \\
\text { Smokers }\end{array}\end{array}$} & \multicolumn{2}{|l|}{ Smokers } & \multirow[b]{2}{*}{$\begin{array}{l}\text { \% Men } \\
\text { among } \\
\text { Smokers }\end{array}$} \\
\hline & & & & $n$ & $\begin{array}{c}\% \\
\text { Men }\end{array}$ & Age & Speciality & & & $\begin{array}{c}\text { Former } \\
\text { Smokers }\end{array}$ & $\begin{array}{c}\text { Total } \\
\text { (Regular \& } \\
\text { Occasional) }\end{array}$ & \\
\hline $\begin{array}{c}\text { Mubeen } \\
2008\end{array}$ & Pakistan & 683 & 2005 & 165 & 43.6 & $\begin{array}{l}20.16- \\
22.89\end{array}$ & Study & 37.5 & 62.5 & $2.4-3.8$ & 14.5 & 95.8 \\
\hline Naji 2006 & Ireland & 32,541 & 2002 & 106 & 61.3 & & Not defined & & & 22.6 & 21.7 & 60.9 \\
\hline $\begin{array}{l}\text { Nakládalová } \\
2005\end{array}$ & Czech Republic & 8033 & 2002-2004 & 370 & 54.9 & & Not defined & & & & 16.8 & 62.9 \\
\hline $\begin{array}{c}\text { Nardini } \\
1998\end{array}$ & Italy & 20,665 & 1995 & 605 & 81.3 & 44 & Not defined & & & 34.4 & 25 & \\
\hline $\begin{array}{c}\text { Nawaz } \\
2007\end{array}$ & Pakistan & 625 & 2004-2005 & 1029 & 44.6 & 21 & Study & 63.5 & 36.5 & 22.4 & 11.2 & 89.6 \\
\hline $\begin{array}{c}\text { Nawaz } \\
2008\end{array}$ & Pakistan & 837 & 2006-2007 & 227 & & & Family medicine & & & & 36.1 & \\
\hline $\begin{array}{l}\text { Ndiaye } \\
2001\end{array}$ & Senegal & 681 & 1999 & 163 & 78.5 & 41 & Not defined & & & 6.8 & 27.6 & 93.3 \\
\hline $\begin{array}{c}\text { Nelson } \\
1994\end{array}$ & USA & & 1974-1991 & 379 & & & Not defined & & & $27.8-32$ & 9 & \\
\hline Ng 2007 & Indonesia & 1065 & 2003 & 447 & & & Not defined & & & & 11.6 & 96.2 \\
\hline Nollen 2004 & Nigeria & 742 & 2002 & 373 & 83.9 & 33 & Not defined & & & & 2.9 & \\
\hline $\begin{array}{c}\text { Nutbeam } \\
1990\end{array}$ & UK & 19,096 & & 304 & 82.6 & & Family medicine & & & 32 & 13.8 & 100 \\
\hline $\begin{array}{c}\text { Obeidat } \\
2017\end{array}$ & Jordan & 4073 & 2014 & 104 & & 42.7 & Not defined & & & & 44.2 & \\
\hline $\begin{array}{l}\text { O'Cathail } \\
2013\end{array}$ & Ireland & 52,105 & 2009-2010 & 248 & & & Not defined & & & $20.8-22$ & 8.1 & 50 \\
\hline Ohida 2001 & Japan & 38,532 & 2000 & 3771 & 66.3 & & Not defined & & & & 20.3 & 88.7 \\
\hline
\end{tabular}


Table 1. Cont.

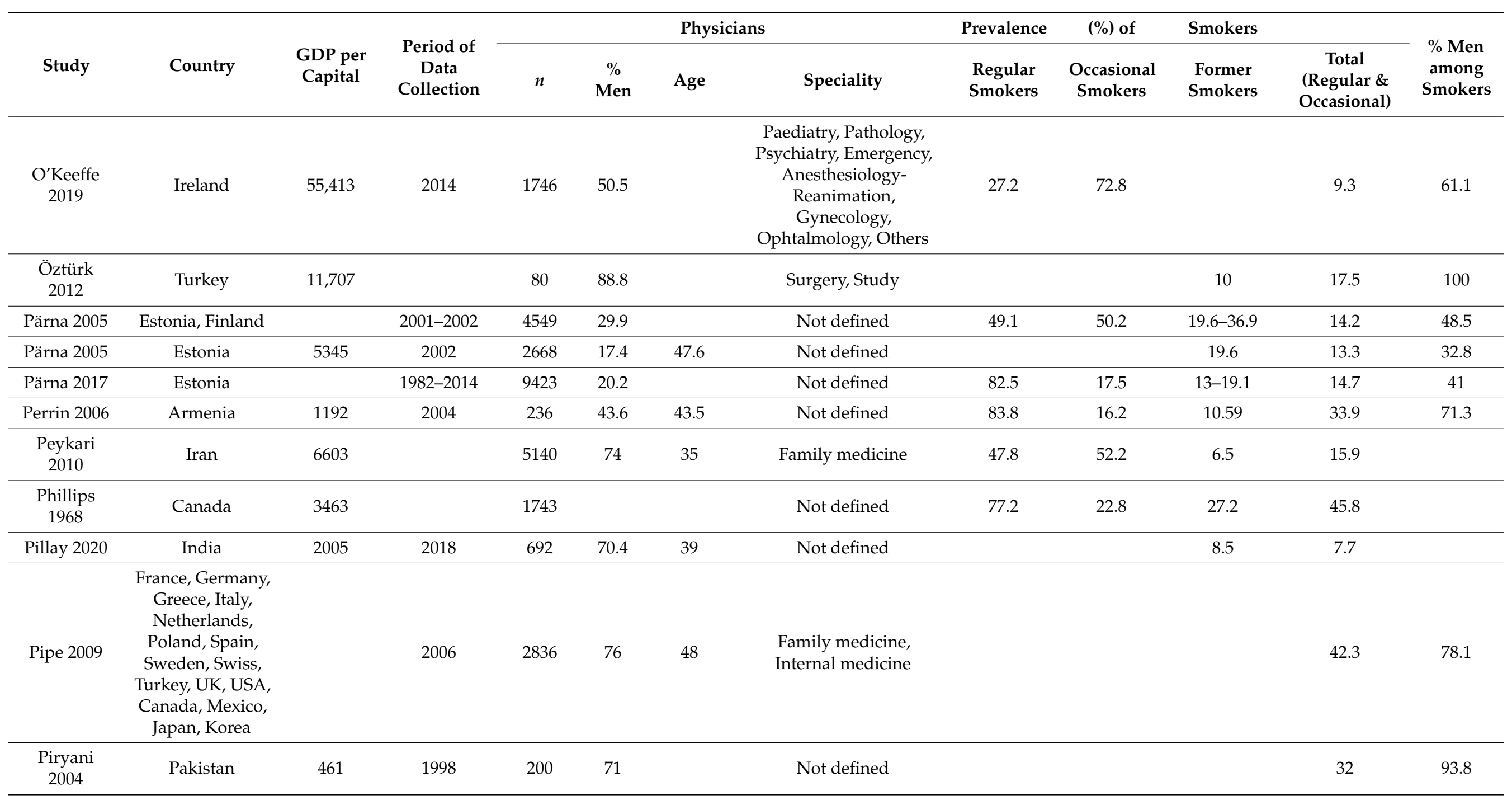


Table 1. Cont.

\begin{tabular}{|c|c|c|c|c|c|c|c|c|c|c|c|c|}
\hline \multirow[b]{2}{*}{ Study } & \multirow[b]{2}{*}{ Country } & \multirow[b]{2}{*}{$\begin{array}{l}\text { GDP per } \\
\text { Capital }\end{array}$} & \multirow[b]{2}{*}{$\begin{array}{l}\text { Period of } \\
\text { Data } \\
\text { Collection }\end{array}$} & \multicolumn{4}{|c|}{ Physicians } & \multirow{2}{*}{$\begin{array}{c}\text { Prevalence } \\
\text { Regular } \\
\text { Smokers }\end{array}$} & \multirow{2}{*}{$\begin{array}{c}(\%) \text { of } \\
\begin{array}{c}\text { Occasional } \\
\text { Smokers }\end{array}\end{array}$} & \multicolumn{2}{|l|}{ Smokers } & \multirow{2}{*}{$\begin{array}{c}\text { \% Men } \\
\text { among } \\
\text { Smokers }\end{array}$} \\
\hline & & & & $n$ & $\begin{array}{c}\% \\
\text { Men }\end{array}$ & Age & Speciality & & & $\begin{array}{l}\text { Former } \\
\text { Smokers }\end{array}$ & $\begin{array}{c}\text { Total } \\
\text { (Regular \& } \\
\text { Occasional) }\end{array}$ & \\
\hline Pizzo 2003 & Italy & 20,088 & 2000 & 526 & & & Family medicine & & & & 28.3 & \\
\hline Poanta 2006 & Romania & 5829 & & 112 & 35.7 & 39.5 & Not defined & & & & 42 & 46.8 \\
\hline Põld 2017 & Estonia & & 2002-2014 & 4877 & 16.9 & & Not defined & 67.5 & 32.5 & & 10.4 & 34.3 \\
\hline $\begin{array}{c}\text { Polyzos } \\
1995\end{array}$ & Greece & 11,176 & 1992 & 148 & & & Not defined & & & & 49.3 & \\
\hline Power 1999 & Ireland & 26,284 & 1999 & 171 & & & Family medicine & & & & 16.1 & \\
\hline $\begin{array}{l}\text { Ramachandran } \\
\quad 2008\end{array}$ & India & 628 & 2004-2006 & 2499 & 75.2 & 39 & Not defined & & & & 8 & 100 \\
\hline $\begin{array}{c}\text { Ranchal } \\
2018\end{array}$ & Spain & & 1986-2016 & 938 & & & Not defined & & & $3.6-20.1$ & 23.2 & \\
\hline Ravara 2014 & Portugal & 23,030 & 2009 & 608 & 37.3 & 39.1 & $\begin{array}{l}\text { Family medicine, Study, } \\
\text { Others }\end{array}$ & & & 17.3 & 20.9 & 52 \\
\hline Reile 2018 & Estonia & 20,367 & 2014 & 1759 & 82.4 & & Not defined & & & & 7.9 & 86.3 \\
\hline Roche 1995 & Australia & 20,320 & 1995 & 1365 & 53.1 & 29.8 & Not defined & & & & 6 & 53.7 \\
\hline Roche 1996 & Australia & 21,861 & 1996 & 908 & 46.9 & 28.7 & Family medicine & & & 8.3 & 4 & \\
\hline Rurik 2008 & Hungary & 10,286 & 2004 & 156 & 42.9 & & Family medicine, Others & & & & 8.3 & 23.1 \\
\hline Rurik 2014 & Hungary & 13,046 & 2009 & 208 & 39.9 & 55.2 & Not defined & & & & 5.8 & 33.3 \\
\hline Saadat 2012 & Scandinavia & & & 58 & 53.4 & & $\begin{array}{l}\text { Anesthesiology- } \\
\text { Reanimation }\end{array}$ & & & & 12.1 & \\
\hline Sachs 1983 & USA & 15,561 & 1983 & 567 & & & Pneumology & & & & 12 & \\
\hline Saeed 1991 & Saudi Arabia & 7839 & & 698 & & & not defined & & & & 34 & \\
\hline Saeys 2014 & Belgium & 47,349 & 2011 & 626 & 57 & 45 & Family medicine & 50 & 50 & 14 & 8 & 72 \\
\hline
\end{tabular}


Table 1. Cont.

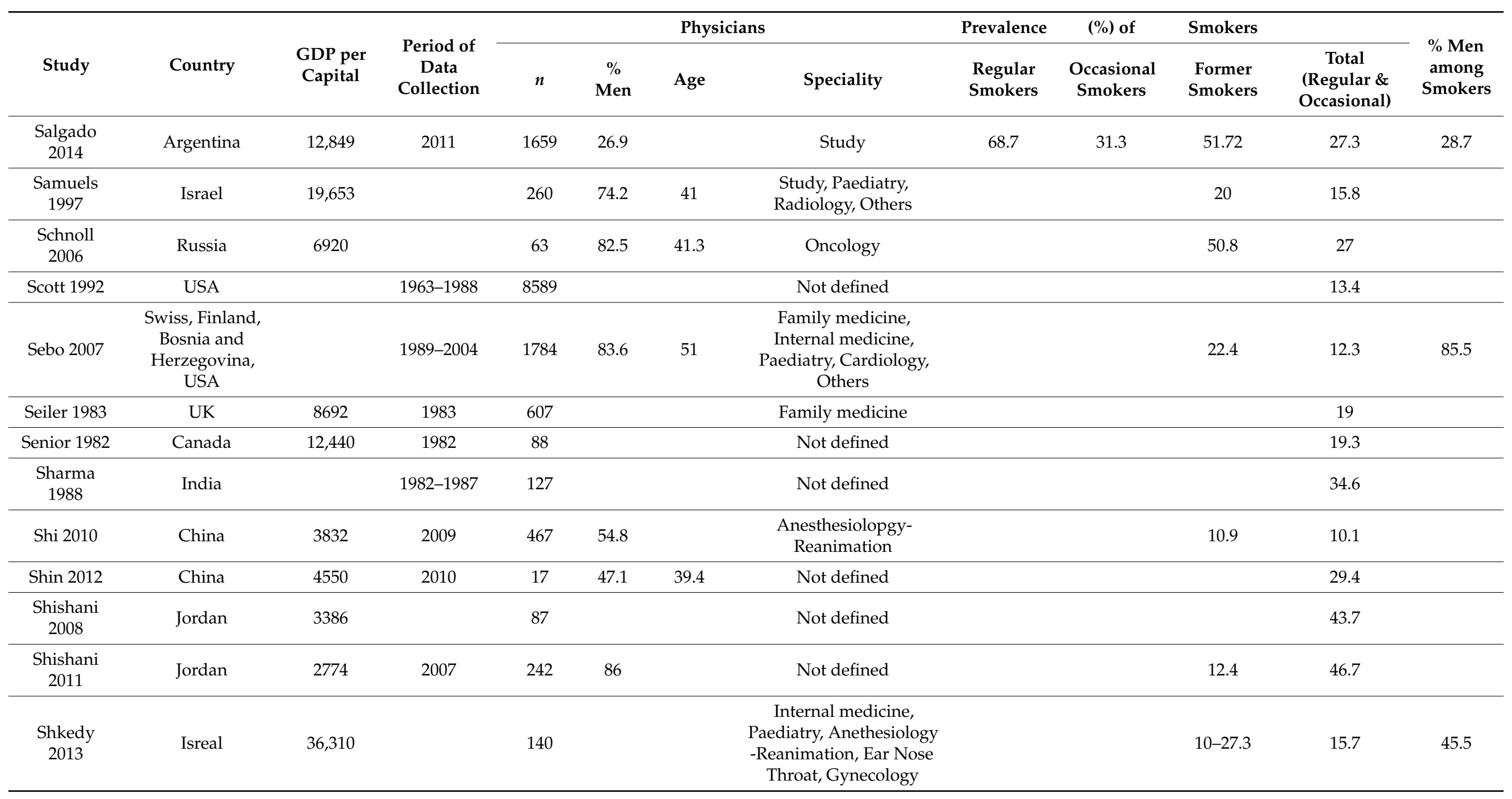


Table 1. Cont.

\begin{tabular}{|c|c|c|c|c|c|c|c|c|c|c|c|c|}
\hline \multirow[b]{2}{*}{ Study } & \multirow[b]{2}{*}{ Country } & \multirow[b]{2}{*}{$\begin{array}{l}\text { GDP per } \\
\text { Capital }\end{array}$} & \multirow[b]{2}{*}{$\begin{array}{l}\text { Period of } \\
\text { Data } \\
\text { Collection }\end{array}$} & \multicolumn{4}{|c|}{ Physicians } & \multirow{2}{*}{$\begin{array}{c}\text { Prevalence } \\
\text { Regular } \\
\text { Smokers }\end{array}$} & \multirow{2}{*}{\begin{tabular}{c|}
$(\%)$ of \\
$\begin{array}{c}\text { Occasional } \\
\text { Smokers }\end{array}$
\end{tabular}} & \multicolumn{2}{|l|}{ Smokers } & \multirow[b]{2}{*}{$\begin{array}{l}\text { \% Men } \\
\text { among } \\
\text { Smokers }\end{array}$} \\
\hline & & & & $n$ & $\begin{array}{c}\% \\
\text { Men }\end{array}$ & Age & Speciality & & & $\begin{array}{l}\text { Former } \\
\text { Smokers }\end{array}$ & $\begin{array}{c}\text { Total } \\
\text { (Regular \& } \\
\text { Occasional) }\end{array}$ & \\
\hline $\begin{array}{c}\text { Siddiqui } \\
2001\end{array}$ & Saudi Arabia & 8685 & & 20 & & & Not defined & & & 10 & 20 & \\
\hline Singh 1981 & India & 186 & 1977-1978 & 861 & & & Study, Others & & & & 27.5 & \\
\hline Smith 2006 & China & 1509 & 2004 & 286 & & & Not defined & & & 1 & 15.7 & \\
\hline Smith 2007 & New Zealand & & 1963-1996 & 22,097 & & & Not defined & & & $19-37$ & 17.9 & \\
\hline $\begin{array}{l}\text { Sotiropoulos } \\
2007\end{array}$ & Greece & 18,478 & 2003-2005 & 1284 & 55.9 & 38.4 & $\begin{array}{l}\text { Family medicine, } \\
\text { Internal medicine, } \\
\text { Biology, Others }\end{array}$ & & & 13.8 & 38.6 & 58.3 \\
\hline Squier 2006 & Ukraine & 1048 & 2003 & 799 & 35.9 & 45 & Family medicine & & & 21.6 & 13.9 & \\
\hline $\begin{array}{c}\text { Steinberg } \\
2007\end{array}$ & USA & 38,166 & 2002 & 334 & 70.7 & 49 & Not defined & & & 23 & 3.3 & \\
\hline Stuyt 2009 & USA & 47,976 & 2007 & 1319 & 68.8 & 44.3 & $\begin{array}{c}\text { Family medicine, } \\
\text { Internal medicine, } \\
\text { Paediatry, Psychiatry, } \\
\text { Emergency, } \\
\text { Anesthesiology- } \\
\text { Reanimation, } \\
\text { Gynecology, Others }\end{array}$ & & & 1 & 38.9 & 75.4 \\
\hline $\begin{array}{c}\text { Sundquist } \\
1999\end{array}$ & Sweden & 32774 & 1996 & 1004 & 46.2 & & Family medicine & & & & 8.4 & 50 \\
\hline $\begin{array}{l}\text { Svärdsudd } \\
2002\end{array}$ & Sweden & 24,225 & 1993-1999 & 974 & & & $\begin{array}{c}\text { Family medicine, } \\
\text { Paediatry, Internal } \\
\text { medicine, Psychiatry, } \\
\text { Radiology, Orthopaedy, } \\
\text { Ear Nose Throat, } \\
\text { Gynecology, Others }\end{array}$ & & & $3-43$ & 7.5 & \\
\hline
\end{tabular}


Table 1. Cont.

\begin{tabular}{|c|c|c|c|c|c|c|c|c|c|c|c|c|}
\hline \multirow[b]{2}{*}{ Study } & \multirow[b]{2}{*}{ Country } & \multirow[b]{2}{*}{$\begin{array}{c}\text { GDP per } \\
\text { Capital }\end{array}$} & \multirow[b]{2}{*}{$\begin{array}{l}\text { Period of } \\
\text { Data } \\
\text { Collection }\end{array}$} & \multicolumn{4}{|c|}{ Physicians } & \multirow{2}{*}{$\begin{array}{c}\text { Prevalence } \\
\text { Regular } \\
\text { Smokers }\end{array}$} & \multirow{2}{*}{$\begin{array}{c}\mathbf{( \% )} \text { of } \\
\begin{array}{c}\text { Occasional } \\
\text { Smokers }\end{array}\end{array}$} & \multicolumn{2}{|l|}{ Smokers } & \multirow[b]{2}{*}{$\begin{array}{l}\text { \% Men } \\
\text { among } \\
\text { Smokers }\end{array}$} \\
\hline & & & & $n$ & $\begin{array}{c}\% \\
\text { Men }\end{array}$ & Age & Speciality & & & $\begin{array}{c}\text { Former } \\
\text { Smokers }\end{array}$ & $\begin{array}{c}\text { Total } \\
\text { (Regular \& } \\
\text { Occasional) }\end{array}$ & \\
\hline $\begin{array}{c}\text { Tapia- } \\
\text { Conyer } \\
1997\end{array}$ & Mexico & 5650 & 1993 & 3488 & 66.2 & 37 & Not defined & & & 20.6 & 26.9 & \\
\hline Tee 2007 & Malaysia & 5594 & 2005 & 481 & 39.1 & & Study & & & 2.7 & 1.7 & 75 \\
\hline $\begin{array}{l}\text { Thankappan } \\
2008\end{array}$ & India & 541 & 2003 & 333 & 77.5 & 42.2 & Not defined & & & 26.1 & 10.8 & 100 \\
\hline $\begin{array}{c}\text { Thomas } \\
1986\end{array}$ & USA & 19,071 & & 106 & 100 & $30.2-30.9$ & Not defined & & & & 13.2 & 100 \\
\hline $\begin{array}{c}\text { Thomas } \\
1997\end{array}$ & USA & & 1957-1965 & 1015 & & $24-27$ & Study & & & & 55.4 & \\
\hline $\begin{array}{l}\text { Tomson } \\
2003\end{array}$ & Laos & 363 & & 151 & 49.7 & & Not defined & 46.2 & 53.8 & & 17.2 & 100 \\
\hline Tong 2010 & USA & 39,497 & 2003-2004 & 1245 & 69.7 & & $\begin{array}{c}\text { Emergency, Psychiatry, } \\
\text { Others }\end{array}$ & & & $18.4-28.8$ & 3.5 & \\
\hline Torre 2005 & USA & & 1948-1964 & 1158 & 91.9 & & Not defined & & & & 51.1 & 91.7 \\
\hline Tosun 2016 & Turkey & 11,336 & 2011-2012 & 224 & 65.2 & 31.71 & Not defined & & & & 28.1 & \\
\hline $\begin{array}{l}\text { Trédaniel } \\
1993\end{array}$ & France & 16,302 & 1987 & 1012 & 87.5 & & Family medicine & & & 29.1 & 36.9 & 89.3 \\
\hline $\begin{array}{l}\text { Ulbricht } \\
2009\end{array}$ & Germany & & & 37 & 51.4 & 47.5 & Family medicine & & & & 24.3 & \\
\hline Unal 2017 & Turkey & & 1975-2004 & 7228 & 66 & 43.6 & Not defined & & & 22.5 & 23.9 & 75.3 \\
\hline $\begin{array}{l}\text { Underner } \\
2004\end{array}$ & France & 24,177 & 2002 & 257 & & & Family medicine & 60.6 & 39.4 & 30.7 & 25.7 & \\
\hline $\begin{array}{l}\text { Underner } \\
2006\end{array}$ & France & 24,177 & 2002 & 257 & & 48 & Family medicine & 61.2 & 38.8 & 31 & 26.1 & \\
\hline
\end{tabular}


Table 1. Cont.

\begin{tabular}{|c|c|c|c|c|c|c|c|c|c|c|c|c|}
\hline \multirow[b]{2}{*}{ Study } & \multirow[b]{2}{*}{ Country } & \multirow[b]{2}{*}{$\begin{array}{l}\text { GDP per } \\
\text { Capital }\end{array}$} & \multirow[b]{2}{*}{$\begin{array}{l}\text { Period of } \\
\text { Data } \\
\text { Collection }\end{array}$} & \multicolumn{4}{|c|}{ Physicians } & \multirow{2}{*}{$\begin{array}{c}\text { Prevalence } \\
\text { Regular } \\
\text { Smokers }\end{array}$} & \multirow{2}{*}{$\begin{array}{c}\mathbf{( \% )} \text { of } \\
\begin{array}{c}\text { Occasional } \\
\text { Smokers }\end{array}\end{array}$} & \multicolumn{2}{|l|}{ Smokers } & \multirow[b]{2}{*}{$\begin{array}{l}\text { \% Men } \\
\text { among } \\
\text { Smokers }\end{array}$} \\
\hline & & & & $n$ & $\begin{array}{c}\% \\
\text { Men }\end{array}$ & Age & Speciality & & & $\begin{array}{l}\text { Former } \\
\text { Smokers }\end{array}$ & $\begin{array}{c}\text { Total } \\
\text { (Regular \& } \\
\text { Occasional) }\end{array}$ & \\
\hline Uysal 2007 & Turkey & 6041 & 2004 & 374 & 66.8 & 46 & Not defined & & & 29 & 16 & 70 \\
\hline $\begin{array}{c}\text { Vanderhoek } \\
2013\end{array}$ & Canada & 52,542 & 2012 & 301 & 48.5 & 24.4 & Study & & & & 15.9 & \\
\hline $\begin{array}{c}\text { Vanphanom } \\
2011\end{array}$ & Laos & 710 & 2007 & 855 & 52.9 & & Not defined & 54.4 & 45.6 & 18.4 & 9.2 & 97.5 \\
\hline Varona 2005 & Cuba & 2308 & 1997 & 121 & 33.1 & & Family medicine & & & & 18.2 & 40.9 \\
\hline Viegas 2007 & Brazil & 4770 & 2005 & 830 & & & Not defined & 81.7 & 18.3 & 22.7 & 7.2 & \\
\hline Voigt 2009 & Germany & 34,044 & 2004-2006 & 912 & & & Not defined & & & & 13.7 & \\
\hline $\begin{array}{c}\text { Waalkens } \\
1992\end{array}$ & Netherlands & 17,398 & 1989 & 1085 & 58.3 & & Study, Others & & & $14.5-34$ & 28.7 & 68.8 \\
\hline Wada 2007 & Japan & 37,218 & 2005 & 196 & 76 & & Not defined & & & & 19.4 & \\
\hline Wang 2021 & China & 9977 & 2018 & 1046 & 61.2 & & Not defined & & & & 14.7 & \\
\hline $\begin{array}{l}\text { Wilf Miron } \\
2019\end{array}$ & Israel & 35,776 & 2015 & 4832 & 59.7 & & Not defined & & & & 8.5 & \\
\hline $\begin{array}{c}\text { Willaing } \\
2003\end{array}$ & Denmark & 33,441 & 1999 & 40 & & & Not defined & & & 23 & 25 & \\
\hline Wilson 2020 & Australia & & & 251 & & & Family medicine & & & & 21.1 & \\
\hline $\begin{array}{c}\text { Wyshak } \\
1980\end{array}$ & USA & 11,674 & 1979 & 289 & 92 & & Not defined & & & & 13.8 & \\
\hline Yaacob 1993 & Malaysia & 2654 & 1991 & 120 & 70.8 & & Not defined & & & 13.3 & 17.5 & 100 \\
\hline Yan 2008 & China & 1289 & 2003 & 358 & & & Not defined & & & 10.6 & 35.8 & \\
\hline Young 1997 & Australia & 21,861 & 1996 & 855 & & & Family medicine & & & & 3.2 & \\
\hline
\end{tabular}


Table 1. Cont.

\begin{tabular}{|c|c|c|c|c|c|c|c|c|c|c|c|c|}
\hline \multirow[b]{2}{*}{ Study } & \multirow[b]{2}{*}{ Country } & \multirow[b]{2}{*}{$\begin{array}{l}\text { GDP per } \\
\text { Capital }\end{array}$} & \multirow[b]{2}{*}{$\begin{array}{l}\text { Period of } \\
\text { Data } \\
\text { Collection }\end{array}$} & \multicolumn{4}{|c|}{ Physicians } & \multirow{2}{*}{$\begin{array}{c}\text { Prevalence } \\
\text { Regular } \\
\text { Smokers }\end{array}$} & \multirow{2}{*}{$\begin{array}{c}\text { (\%) of } \\
\begin{array}{c}\text { Occasional } \\
\text { Smokers }\end{array}\end{array}$} & \multicolumn{2}{|l|}{ Smokers } & \multirow[b]{2}{*}{$\begin{array}{c}\text { \% Men } \\
\text { among } \\
\text { Smokers }\end{array}$} \\
\hline & & & & $n$ & $\begin{array}{c}\% \\
\text { Men }\end{array}$ & Age & Speciality & & & $\begin{array}{l}\text { Former } \\
\text { Smokers }\end{array}$ & $\begin{array}{c}\text { Total } \\
\text { (Regular \& } \\
\text { Occasional) }\end{array}$ & \\
\hline Zabadi 2018 & Paslestine & & 2005 & 502 & 80.1 & 34.92 & $\begin{array}{c}\text { Family medicine, Study, } \\
\text { Others }\end{array}$ & & & 12.2 & 39.6 & 64.8 \\
\hline $\begin{array}{c}\text { Zanetti } \\
1998\end{array}$ & Italy & 23,020 & 1996 & 393 & 74 & & Not defined & & & & 31 & 68.9 \\
\hline Zhang 2015 & China & 8069 & & 8725 & & & Study, Others & & & & 12.8 & 96.7 \\
\hline Zhou 2010 & China & 2694 & 2007 & 673 & 73.3 & & Not defined & & & 5 & 26.2 & 96.6 \\
\hline $\begin{array}{l}\text { Zinonos } \\
2016\end{array}$ & Cyprus & 35,391 & 2008 & 119 & 59.7 & & Not defined & & & 16 & 28.6 & \\
\hline $\begin{array}{c}\text { Zylbersztejn } \\
2015\end{array}$ & Argentina & 13,080 & 2013 & 3033 & & 41.3 & Not defined & & & 21.7 & 19.7 & \\
\hline
\end{tabular}




\subsection{Quality of Articles}

Using the NOS criteria for cross-sectional studies demonstrated a low risk of bias, except for sample size (not clearly defined in $75 \%$ of studies), representativeness (comparability bias in $82 \%$ of studies), and statistical tests (not or incompletely described in $49 \%$ of studies) (Figure 2). NOS for cross-sectional and cohort assessment are shown in Figure S1 in Supplement. STROBE and CONSORT assessment are shown in Table A1.

\section{Risk of bias summary \\ Cross sectionnal Studies}

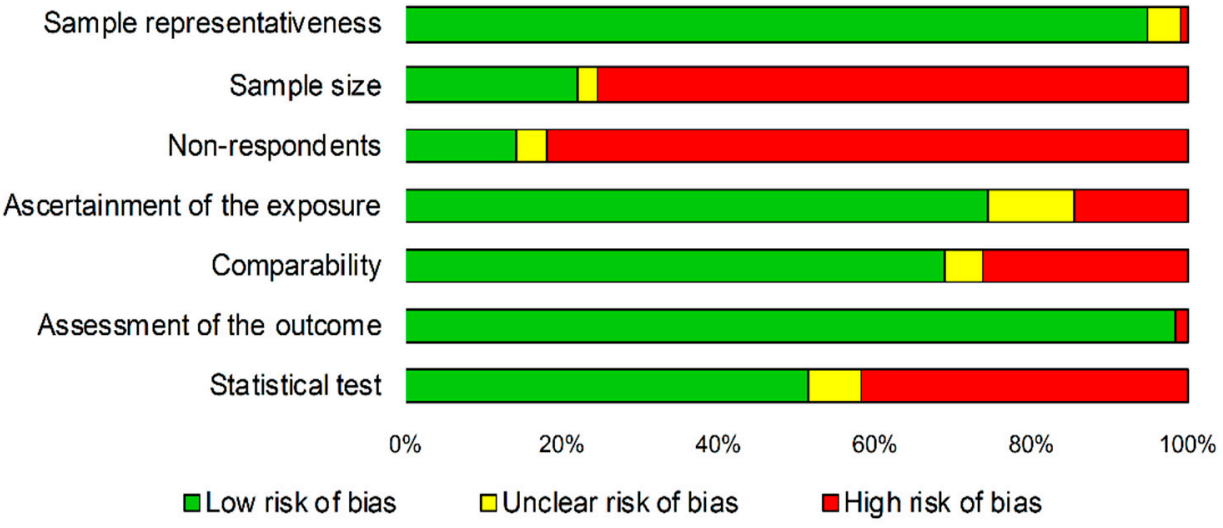

Figure 2. Risk of bias using Newcastle Ottawa Scale composed by seven level of bias assessment.

\subsection{Study Designs and Objectives}

Most (94\%) studies were cross-sectional [7,8,21-250]. However, twelve were cohort [251-262] and two were clinical trials [263,264]. Every one of the included 246 studies described smoking prevalence among physicians. The main aim of examining smoking prevalence among physicians was reported in most studies $(n=117)[24,26$, $27,29,32,33,35-41,44,45,48,49,53-56,58,59,68,69,72,73,76,78,82,84,85,87,90-95,97-99,102-$ $104,107,108,110,115,119-121,126,131-133,135-138,141,142,144-149,151,154,156-158,160$, $161,163-165,167,169-172,174,176,178-180,182,183,185,187,189-194,196,197,199,201-204$, $207,211,213,218,224,225,227,231,239,241-243]$. Fifteen studies also aimed to assess the use of other substances in physicians [29,37,93-95,117,118,124,141,161,165,171,193,239,248]. Other outcomes presented were demographic characteristics and health status of physicians in 58 studies $[22,23,30,31,42,43,46,57,60,63-66,74,75,80,88,89,96,100,106,114,116$, $123,125,128-130,134,139,143,153,155,162,176,177,181,184,195,198,208,223,238,239,249,251-$ $261,263,264]$, the evaluation of smoking cessation counselling among physicians in 50 studies $[25,26,28,33,35,40,55,61,62,67,70,79,86,92,97,99,101,104,105,111,136,142,144,145,152,157$, $168,183,189-191,197,201,203-205,209,210,212,214,218,219,234-236,241,242,244,247,250]$, the attitude of physicians towards prevention and promotion of a healthy lifestyle in seven studies $[122,140,206,208,220,222,228]$, the knowledge on tobacco effects in 20 studies $[24,33,39,44,50,53,61,62,78,91,98,119,154,178,199,204,216,217,240,247]$, and the examination of the link between smoking habits of physicians and their practice of providing minimal smoking cessation advice in 26 studies $[7,8,21,47,58,81,83,109,112,127,150,159,175,186-$ $188,208,211,213,224,225,232,237,244,246,262]$. Finally, the primary outcome was not clearly defined in 16 studies [34,51,52,71,77,113,166,173,200,215,221,226,229,230,233,245].

\subsection{Recruitment of Physicians}

Physicians were recruited from health centers in 94 studies, either monocentric in 50 studies $[21,26,29,30,37,41-43,46,49,56,79,80,97,115,120,121,132-134,156,162,163,167$, $170,179,181,182,184,190,193,194,196,202,204,212,217,225,228,229,232,235,244,250,256,257$, $259,260,263,264]$ or multicentric in 44 studies $[24,39,53,54,72,83,89-92,98,111,112,117$, $119,123,126,128,130,131,141,152,168,169,178,197,201,203,205,207,214,216,219,220,224,227,231$, $236-238,242,243,253,261]$. They were also recruited from specific lists in 68 studies, either 
from specific societies in 14 studies $[22,40,47,77,78,110,158,180,183,189,221,222,230,240]$, associations in 23 studies [7,59,67,87,94,95,106-108,118,129,135,142,206,209,223,234,239,245, $249,251,254,262]$, medical or specific registers in 22 studies, [23,38,85,88,113,127,139,144, $145,154,159,165,173,177,186,192,199,208,210,246,248,258]$ and lists from ministries of health in 9 studies $[33,35,45,99,116,140,146,166,218]$. Finally, recruitment procedure was not defined in 84 studies $[8,25,27,28,31,32,34,36,44,48,50-52,55,57,58,60-66,68-71,73-76,81,82,84,86$, 93,96,100-105,109,114,122,124,125,136-138,143,147-151,153,155,157,160,161,164,171,172,174176,185,187,188,191,195,198,200,211,213,215,226,233,241,247,252,255]. Smoking prevalence was also described in non-physicians in 30 studies $[24,39,40,52,69,74,79,86,91,99,102,104$, $105,110,113,125,129,133,135,139,143,151,161,162,176,185,195,197,202,235]$.

\subsection{Populations Studied}

Sample size ranged from 17 [235,237] to 31,208 [64]. In total, 497,081 physicians were included in this meta-analysis.

Age of physicians was reported in 89 studies. Overall, the mean age was 41.5 years old (95\%CI 38.4 to 44.6), ranging from 20.2 [132] to 59.8 [109] years old (Table 1).

Gender was reported in more than half of the studies $(n=165)$ on the total population of physicians, among which 107 studies also reported gender of smoking physicians. The mean number of men was $62 \%$ (58 to 65\%), ranging from 0 in five studies that included only women, to $100 \%$ in thirteen studies that included only men (Table 1).

Specialty was reported in 96 studies. Family practitioners were the most represented (56 studies, $n=64,187$ physicians), followed by medical students ( 27 studies, $n=28,564$ ), medical specialties (39 studies, $n=15,538$ ), anesthesiologists (15 studies, $n=3329$ ), surgical specialties (17 studies, $n=2395)$, pediatrics (11 studies, $n=1847)$, psychiatrists ( 8 studies, $n=1393$ ), and radiologists (7 studies, $n=1193$ ) (Table 1 ).

Location of studies was always reported. Most studies were conducted in Europe (89 studies, $n=20,509$ ), followed by America (56 studies, $n=126,615)$, Asia (83 studies, $n=104,325)$, Oceania (13 studies, $n=59,609)$, and Africa ( 8 studies, $n=2023$ ) (Table 1 ).

Other variables were less well described. Family status was reported in 29 studies $[22,42,45,74,79,85,89,92-94,103,105,112,121,125,128,130,137,143,161,174,179,195,199,229$, $244,250,257,264]$, workplace was the focus in 42 studies (most worked in public sectors) $[22,28,40,47,58,61,75,79,88,94,96,104,105,125,130,133-135,137,148-150,155,161,163,172$, $174,180,185,186,189,199,203,218,219,223,226,229,234,239,240,242]$, working hours per week was reported in 8 studies (ranging from 37 [25] to 79 [80] hours per week) [22,25,58,75,80, $143,195,213]$, seniority of physician was reported in 14 studies (ranging from 6.5 [205] to 20.8 [28] years ago) $[25,28,36,58,78,96,126,130,137,140,150,184,204,205]$, BMI in 17 studies (ranging from 21 [260] to 27.7 [257] kg/m²) [23,30,42,66,80,88,96,130,139-141,244,249,255, $257,259,260]$, and physical activity in 24 studies (most physicians were active) $[30,42,46,57$, $75,88,89,96,100,121-123,125,129,130,134,139,140,143,195,238,239,255,257]$.

\subsection{Smoking Assessment}

Most studies used a self-administered questionnaire (postal and email) (209 studies) $[7,8,21-33,36-54,56,57,59-72,75-88,90-96,98,99,102,105-109,111,112,114,116-135,137,139$ 149,151,153,154,157-174,176-182,184-186,189,190,192-199,201-203,205-207,209-215,217-225, 227-232,234-242,244-246,248-257,259,260,262-264]. Other studies collected data by interview (11 studies) [35,55,100,101,150,155,156,175,191,208,261], interview and postal (7 studies) $[58,73,74,115,183,187,188]$, phone (9 studies) $[89,103,104,136,152,204,216,226,233]$, and phone and postal (1 study) [98]. The data collection method was unclear in nine studies $[34,97,110,113,138,200,243,247,258]$. The definition of smoking used was not explained in most (96.2\%) included articles. In eight studies, smoking was defined by one cigarette per day $[24,93,142,156,162,202,203,220]$. In five studies, a smoker was defined as a person who had smoked at least 100 cigarettes or an equivalent amount of tobacco in their lifetime [24,138,178,202,261]. Two studies specified whether smokers were cigarette, pipe, or cigar smokers $[114,115]$. Around half of the studies reported the prevalence of ex- 
smokers (135 studies, $n=47,688$ ) (Table 1 ). As with smoking, the definition of ex-smoking was not explained in most (95.2\%) included articles. In five studies, an ex-smoker was defined as someone who stopped smoking completely for at least 3 [220], 6 [142,261], or 12 months [24,224]. Publication occurred within 2 years of data collection for 31\% of studies, within 2 to 5 years for $45 \%$, and more than 5 years for $10 \%$-and was not reported for $14 \%$ of studies. Most studies were published between 2000 and 2015 (138 studies, $n=232,323$ ), followed by studies published between 1985 and 2000 (54 studies, $n=85,402$ ), after 2015 (31 studies, $n=94,637$ ), and before 1985 (23 studies, $n=84,719)$. Studies ranged from 1954 [63] to 2021 [243,247] (Table 1).

\subsection{Meta-Analysis on the Smoking Prevalence among Physicians}

The smoking prevalence among physicians was around 21\% (95CI 20 to 23\%). Stratified by specialty, prevalence of smoking was $25 \%$ (21 to $29 \%$ ) in medical students, $24 \%$ (22 to $26 \%$ ) in family practitioners, $18 \%$ (12 to $23 \%$ ) in surgical specialties, $17 \%$ (10 to $23 \%$ ) in psychiatrists, $16 \%$ (14 to $17 \%$ ) in medical specialties, $11 \%$ (8 to $15 \%$ ) in anesthesiologists, $9 \%$ (5 to $13 \%$ ) in radiologists, and $8 \%$ (6 to $11 \%$ ) in pediatrics. Stratification by continent showed the prevalence of smoking in physicians ranging from $11 \%$ in Oceania to $25 \%$ in Europe and Asia. The smoking prevalence among physicians decreased over time: $28 \%$ ( 22 to $33 \%$ ) before $1985,22 \%$ (19 to $25 \%$ ) between 1985 and $2000,20 \%$ (19 to $21 \%$ ) between 2000 and 2015, and 16\% (14 to 18\%) after 2015. All $\mathrm{I}^{2}$ were extremely high within each stratification, i.e., $>99 \%$, except two $\mathrm{I}^{2}$ that were at 86 and $94 \%$ (Figure 3 ).

\subsection{Meta-Regressions}

Family practitioners and medical students had a higher smoking prevalence than anesthesiologists (Coefficient 0.12, 95CI 0.04 to 0.19, and 0.12, 0.03 to 0.20, respectively), pediatrics $(0.12,0.03$ to 0.21 and $0.13,0.03$ to 0.23$)$, radiologists $(0.12,0.02$ to 0.22 , and 0.12 , 0.02 to 0.23$)$, and other medical specialties $(0.07,0.01$ to 0.12 , and $0.08,0.01$ to 0.15$)$. For comparisons between continents, physicians in Europe and Asia had a higher smoking prevalence than in North America (0.07, 0.04 to 0.11 , and $0.08,0.04$ to 0.11 , respectively) and Oceania $(0.12,0.09$ to 0.16 , and $0.13,0.08$ to 0.17$)$. Smoking prevalence in North America was also significantly higher than in Oceania $(0.05,0.01$ to 0.09$)$. Lastly, smoking prevalence was the highest before 1985 (0.06, 0.01 to 0.10 vs. between 1985 to 2000; 0.08, 0.04 to 0.12 vs. between 2000 to 2015; 0.11 , 0.05 to 0.16 vs. after to 2015). Moreover, the smoking prevalence between 1985 and 2000 was higher than after $2015(0.05,0.01$ to 0.09). Male physicians had a higher smoking prevalence than women $(0.01,0.00$ to 0.01$)$. Age did not influence smoking prevalence (Figure 4). Insufficient data precluded other meta-regressions.

\subsection{Sensitivity Analyses}

Funnel plots of meta-analyses analyzing for potential publication bias are presented in Figure 2. Due to the huge heterogeneity (most $\mathrm{I}^{2}$ being $>99 \%$ ), we did not reperform meta-analyses after the exclusion of studies that were not evenly distributed around the base of the funnel. Lastly, we performed all aforementioned analyses on the prevalence of ex-smokers. The prevalence of ex-smokers among physicians was around 23\% (95CI 21 to $25 \%)$. Psychiatrists also had a high prevalence of ex-smokers (29\%, 19 to 40\%), followed by other specialties. Contrary to meta-analyses on current smokers, medical students had a low rate of ex-smokers (11\%, 6 to $17 \%)$. Interestingly, if prevalence of current smokers was similarly high in Europe and Asia (25\%), there was greater prevalence of ex-smokers in Europe $(25 \%, 21$ to $29 \%)$ than in Asia (17, 14 to 20\%) $(p<0.001)$. North America and South America also had a high prevalence of ex-smokers (27\%, 20 to 34\%; and 26\%, 14 to $38 \%$, respectively), whereas Africa had a low prevalence of ex-smokers ( $\% \%, 6$ to $10 \%)$. The prevalence of ex-smokers decreased in similar proportions over time: $31 \%$ (26 to 35\%) before 1985, 24\% (18 to 30\%) between 1985 and 2000, 22\% (19 to 24\%) between 2000 and 2015, and 21\% (14 to 28\%) after 2015 (Figures 3 and 4). 


\begin{tabular}{|c|c|c|c|c|}
\hline Variables & $\begin{array}{c}\text { n studies } \\
\text { (n subgroups) }\end{array}$ & & $\begin{array}{l}\text { Percentage of } \\
\text { smokers }(95 \mathrm{Cl})\end{array}$ & $\begin{array}{c}\text { Weight } \\
(\%)\end{array}$ \\
\hline \multicolumn{5}{|l|}{ By speciality } \\
\hline Medical students & $27(36)$ & $\curvearrowright$ & $25 \% \quad$ (21 to $29 \%)$ & 5.9 \\
\hline Family medicine & $56(93)$ & $\diamond$ & $24 \% \quad$ (22 to $26 \%)$ & 16.5 \\
\hline \multicolumn{5}{|l|}{ Surgical specialities } \\
\hline Chest surgery & $1(1)$ & $-\circ$ & $13 \% \quad(10$ to $16 \%)$ & 0.2 \\
\hline Ear Nose Throat & $3(4)$ & - & $21 \% \quad(10$ to $31 \%)$ & 0.4 \\
\hline Gynecology & $10(14)$ & - - & $20 \% \quad(13$ to $26 \%)$ & 2.4 \\
\hline Ophtalmology & $1(1)$ & o- & $2 \% \quad(1$ to $5 \%)$ & 0.2 \\
\hline Orthopaedy & $2(2)$ & $-0-$ & $5 \% \quad(1$ to $9 \%)$ & 0.4 \\
\hline Overall surgical specialities & $17(21)$ & $\sim$ & $18 \% \quad(12$ to $23 \%)$ & 3.6 \\
\hline Psychiatry & $8(8)$ & $\infty$ & $17 \% \quad(10$ to $23 \%)$ & 1.4 \\
\hline \multicolumn{5}{|l|}{ Medical specialities } \\
\hline Biology & $2(2)$ & $-0-$ & $24 \% \quad(17$ to $31 \%)$ & 0.3 \\
\hline Cardiology & $5(5)$ & $-\circ-$ & $13 \% \quad(4$ to $23 \%)$ & 0.9 \\
\hline Dermatology & $1(1)$ & - & $16 \% \quad(7$ to $32 \%)$ & 0.2 \\
\hline Emergency & $5(5)$ & $\longrightarrow \mathrm{O}-$ & $13 \% \quad(5$ to $21 \%)$ & 0.9 \\
\hline Internal medicine & $14(14)$ & $-0-$ & $22 \% \quad(13$ to $30 \%)$ & 2.5 \\
\hline Oncology & $1(1)$ & $\longrightarrow$ & $27 \% \quad(18$ to $39 \%)$ & 0.2 \\
\hline Pathology & $4(4)$ & $-0-$ & $11 \% \quad$ (3 to $19 \%)$ & 0.7 \\
\hline Pneumology & $5(5)$ & $\longrightarrow$ & $12 \% \quad(2$ to $22 \%)$ & 0.9 \\
\hline Public health & $2(2)$ & $\longrightarrow$ & $23 \% \quad(13$ to $33 \%)$ & 0.3 \\
\hline Overall medical specialities & $39(39)$ & $\diamond$ & $16 \% \quad(14$ to $17 \%)$ & 6.9 \\
\hline Anesthesiology & $15(16)$ & $\prec$ & $11 \% \quad$ (8 to $15 \%)$ & 2.9 \\
\hline Radiology & $7(9)$ & $\prec$ & $9 \% \quad(5$ to $13 \%)$ & 1.6 \\
\hline Paediatry & $11(11)$ & $\checkmark$ & $8 \% \quad(6$ to $11 \%)$ & 2.1 \\
\hline Undefined & $150(307)$ & $\downarrow$ & $21 \% \quad(19$ to $24 \%)$ & 59.1 \\
\hline \multicolumn{5}{|l|}{ By continent } \\
\hline Europe & $89(221)$ & $-0-$ & $25 \% \quad$ (21 to $28 \%)$ & 2.2 \\
\hline Asia & $83(137)$ & $-\circ-$ & $25 \% \quad(22$ to $27 \%)$ & 24.0 \\
\hline Central America & $1(1)$ & -O= & $18 \% \quad(12$ to $26 \%)$ & 0.17 \\
\hline North America & $46(116)$ & .0 & $17 \% \quad(15$ to $18 \%)$ & 38.2 \\
\hline South America & $9(9)$ & - & $17 \% \quad(10$ to $24 \%)$ & 21.3 \\
\hline Africa & $8(12)$ & - & $17 \% \quad(11$ to $23 \%)$ & 12.1 \\
\hline Oceania & $13(67)$ & 0. & $11 \% \quad(10$ to $13 \%)$ & 1.7 \\
\hline \multicolumn{5}{|l|}{ By time } \\
\hline$>2015$ & $31(76)$ & o. & $16 \% \quad(14$ to $18 \%)$ & 10.9 \\
\hline 2000-2015 & $138(288)$ & 0 & $20 \% \quad(19$ to $21 \%)$ & 52.0 \\
\hline 1985-2000 & $54(141)$ & 0 & $22 \% \quad(19$ to $25 \%)$ & 25.5 \\
\hline$<1985$ & $23(65)$ & $\circ$ & $28 \% \quad(22$ to $33 \%)$ & 11.6 \\
\hline \multirow[t]{2}{*}{ Overall } & $246(570)$ & $\diamond$ & $21 \% \quad(20$ to $23 \%)$ & 100.0 \\
\hline & & $\begin{array}{llll}10 & 20 & 30 & 40\end{array}$ & & \\
\hline
\end{tabular}

Figure 3. Meta-analysis on prevalence among physicians stratified by specialty, continent, and time. Results are expressed in percentage from 0 to 100. Bold represent a stratification or overall result. 


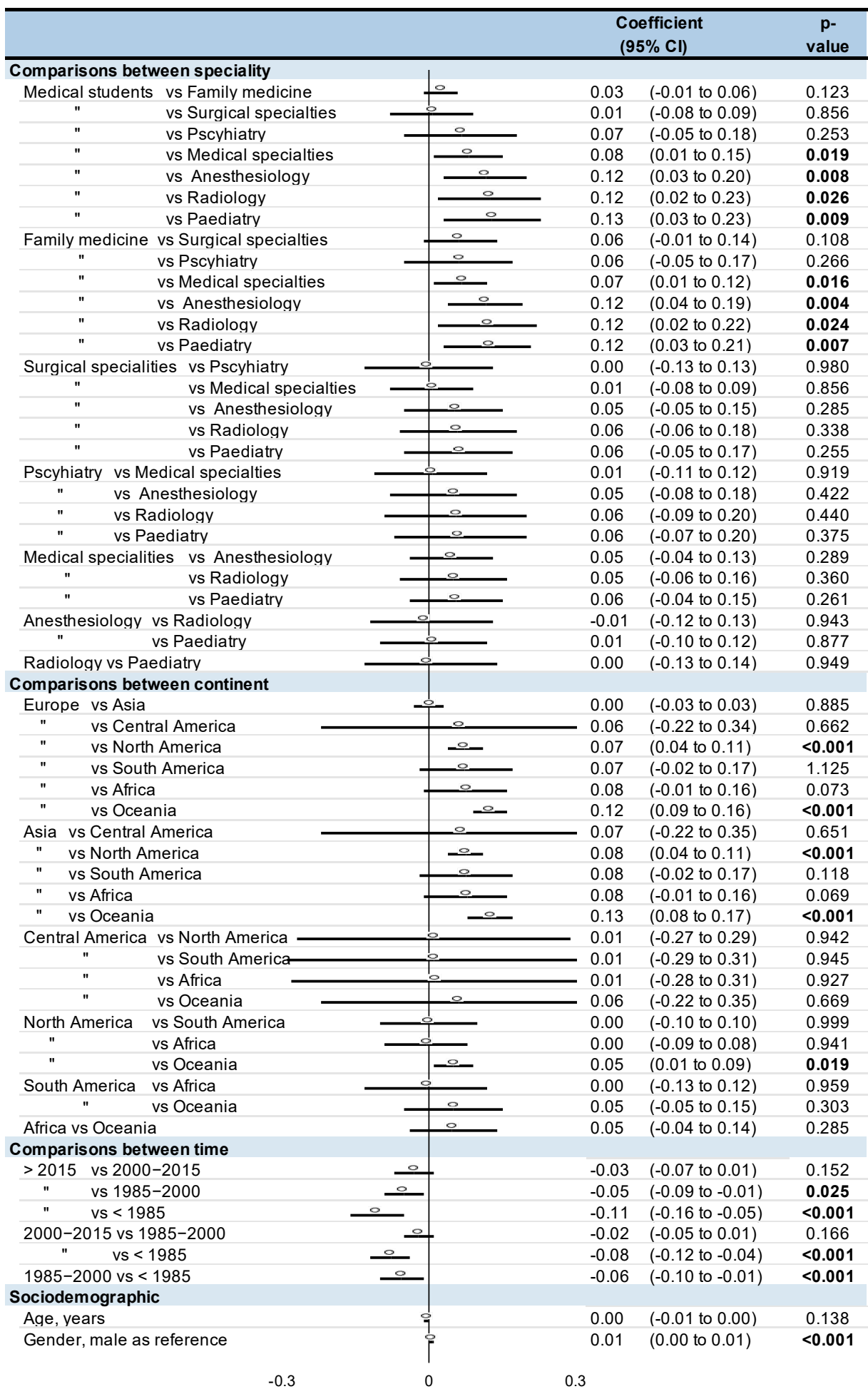

Figure 4. Meta-regressions. "means 'same as' the line above. Bold represent a stratification.

\section{Discussion}

The main findings were that the prevalence of smoking among physicians is high, around $21 \%$. Family practitioners and medical students have the highest percentage of smokers and should benefit from targeted preventive strategies. Smoking in physicians is a public health issue that is common, both in developed and developing countries, even if quitting smoking is higher in developed countries. Positively, the prevalence of smoking decreased over time. 


\subsection{Smoking among Physicians: A Public Health Issue}

Surprisingly, prevalence of smoking among physicians is high, which may seem unlikely because they should be an example for their patients and should know the health risks linked to tobacco [21]. This said, even if there is no study determining whether being a physician is a risk factor for smoking compared to the general population, they seem to follow similar trends and are highly concerning [265]. Literature shows that disadvantaged populations smoke more than others [266]. In some way, physicians can also be considered as disadvantaged due to their cumulative risk factors for smoking. They face a huge workload, working over $55 \mathrm{~h}$ a week [22]. Stress at work could play a major role in their smoking habits [22]. Overload of stress can even contribute to depressive disorders and high risk of suicides, that are also risk factors of smoking $[267,268]$. They also work nightshifts [43], disrupting the circadian rhythm that can heighten smoking behavior [269]. Moreover, despite the consequences for themselves, physicians who smoke are less likely to promote quitting smoking for their patients $[7,21]$. Therefore, there is a need to tackle physicians smoking behavior both for themselves and their patients. Smoking in physicians must be considered as a major public health problem. Alarmingly, even our massive search did not find governmental actions for quitting smoking in physicians. In the research, we found several randomized controlled trials on strategies for smoking cessation in homeless people $[270,271]$, but none in physicians.

\subsection{Depending on Specialties}

The smoking prevalence was higher among medical students and family practitioners. For medical students, the high prevalence of smoking may be explained due to the stress of hard academic studies [272]. Moreover, medical students can have high risk-taking behaviors such as partying and tobacco consumption $[273,274]$. The high prevalence among family practitioners might be explained by several putative factors such as workload [22], stress [22], and lack of cohesive teamwork [275]. Workload and stress have been shown in the literature as an important risk factor of smoking [22]. The work environment, such as the lack of cohesive teamwork, is a risk factor of depression and drug use [275], with depression and drug use being linked [60]. Similarly, workload [22] and work stress [22] can also contribute to the high prevalence of smoking in surgical practitioners, who can face legal issues as part of their work [276]. Experiencing judgement in court and repeated trials could promote depression and, in turn, smoking [276]. For psychiatrists, contributing factors of smoking could be the fact that they are routinely faced with traumatic experiences [277], incurable diseases [278], and breaking bad news to patients [278]. Conversely, pediatrics smoked the least, probably because they most often deal with common and curable diseases [279]. Moreover, pediatricians are predominantly women [280]. Although we found a higher prevalence of smoking among women, the literature described a lower rate of smoking among women compare to men in the general population $[45,243]$. A common characteristic of all specialties is that smoking cessation training during medical studies was poor or not important enough [62,70]. This may contribute to the high prevalence of smoking among physicians. Considering that nearly all physicians will encounter smoking patients, improving smoking cessation training during their studies could help both their patients to quit smoking, as well as the physicians themselves.

\subsection{Depending on Continents}

Smoking prevalence was not homogeneous between continents. Europe and Asia were continents where the smoking prevalence among physicians was the highest. Conversely, Oceania was the continent where the smoking prevalence among physicians was the lowest. This heterogeneous prevalence was probably in line with tobacco culture [281] and tobacco marketing [281] in many countries. Tobacco culture in Europe was brought by Christopher Colombus in the 16th century [282], firstly as a luxury product [13]. But during the 20th century, tobacco became accessible for all and became a trendy product [13]. Then, in developed countries, tobacco became undesirable [283]. Recent literature shows 
that tobacco marketing targeted more poor countries [284]. India is the country on the Asian continent with the poorest population, and represents about $17 \%$ of the global population [285-287]. Moreover, tobacco control is less important in Asia [288]. Studies conducted in Oceania were conducted in rich countries, i.e., Australia and New Zealand, that may be the two countries with the strongest anti-smoking policy [289]. In those two countries, the price of cigarettes is among the most expensive. The increasing taxes aided the decrease in prevalence of smoking, which can be an easy reproducible preventive strategy in other countries [290]. In 2012, Australia was the first country to use plain cigarette packaging [291,292]. A national tobacco campaign in Australia showed the benefits of stopping smoking rather than the negative effects of tobacco [293]. In New Zealand, smoking is prohibited in motor vehicles carrying children under the age of 18 [294]. Finally, except in those two countries that manage smoking, smoking is still a major public health issue worldwide, both in developed and developing countries.

\subsection{With a Time Effect}

The smoking prevalence among physicians decreased overtime. We showed that physicians' smoking prevalence has decreased since 1985. The knowledge of the health risks of tobacco during the 1970s changed tobacco from a positive to a negative image [13]. The most recent studies (after 2015) showed that the prevalence of tobacco in physicians continued to decrease. Universally, this decrease was probably related to the tobacco control implemented by the WHO [295], such as a tobacco free-day since 1987 [296]. The WHO Framework Convention on demand and supply reduction [295] probably played a major role in the tobacco consumption decline. Since 2003, European directives limit physicians' work to 48 h per week $[297,298]$, which may have lessened the stress of physicians. The development of new technologies has encouraged public health advocates to adapt to target a younger cohort, such as the creation of a mobile app for assisting smokers [299], sending emails [300], or sending mobile text messaging [300]. Even if the number of studies on the toxicity of electronic cigarettes remains low, it seems interesting to help with smoking cessation [301]. In Canada, mailed distribution of free nicotine patches seems beneficial, particularly among the financially disadvantaged [302]. In France, nicotine substitutes are reimbursed at $65 \%$ by the National Health system as of January 2019 [303]. Our metaanalysis showed that many studies were carried out between 2000 and 2015, probably to assess the effectiveness of tobacco control [295]. Interestingly, preventive strategies sometimes took advantage of context. With the COVID pandemic, Santé Publique France led a digital campaign and special operation to promote the tobacco control [304], based on the fact that tobacco aggravates COVID's symptoms [305]. That said, the decrease in smoking prevalence could continue in the coming years.

\subsection{Other Influencing Variables}

Male physicians always smoked more than women, probably because of social habit [306]. There was no significant effect of age on the smoking prevalence of physicians, however, smoking prevalence among the general population decreases with age [307,308]. Insufficient data precluded further analyses on putative influencing factors such as physical activity, BMI, number of hours worked per week, workplace setting, or family status. For example, lower physical activity and higher waist circumference were associated with tobacco consumption [309]. Leisure physical activity of physicians is low [310], which can be limited by their workload [310]. Low levels of physical activity also contribute to burnout [311], that, in turn, increases smoking [22]. No study compared smoking prevalence based on the type of practice (public or private practice). Even if being divorced or separated is a risk factor for smoking in the general population [312,313], the influence of family status in physicians has not been reported. To our knowledge, smoking prevalence of physicians was never compared with smoking prevalence of the general population. Physicians also have protective factors of smoking. For example, their level of study is above the baccalaureate [307], their income is higher than the average population [307], 
and they are most likely to know tobacco risks [21]. Considering that physicians combine risk and protective factors of smoking, comparisons with the general population may be of particular interest to target appropriate preventive strategies.

\subsection{Limitations}

Our study has some limitations. We conducted our meta-analyses on only published articles, so our results were, theoretically, exposed to a publication bias. We included only studies reporting physicians' smoking prevalence and only studies written in English or French, so our results were, theoretically, exposed to a selection bias. Most cross-sectional studies included in our meta-analysis described a bias of self-report. Data were collected by self-administered questionnaire, not always anonymously. Thus, the reporting of smoking might have been underestimated by physicians. Another limitation could be the number of different studies included and the number of physicians included. Although we did not find any double inclusion, it could be possible that some physicians were included twice, creating an overlap that might introduce some bias. Our meta-analysis also had limitations on the definition of smoking. In fact, the definition used to define regular smokers, occasional smokers, or former smokers was different between studies and was rarely detailed. Therefore, the meta-analysis inherited the limitations of the individual studies of which they were comprised: varying quality of studies, multiple variations in study protocols, and evaluation. Comparisons between specialties might suffer from a bias, such as a different number of physicians within each specialty. Moreover, our meta-analysis had a lot of studies with undefined specialties. Similarly, some authors suggested that the medical field was mainly dominated by the male gender and reported a poor status integration of women physicians within the profession [314]. Comparisons between continents or time period might also suffer from a different number of studies within each continent or each period; however, our review provided a massive sample of nearly half a million physicians promoting generalizability of our results.

\section{Conclusions}

We found that the prevalence of smoking among physicians is high, around $21 \%$. There is an important heterogenicity between specialties, continents, and periods of time. Despite family practitioners and medical students being the heaviest smokers, all physicians should benefit from targeted preventive strategies. Smoking in physicians is a public health issue that is common, both in developed and developing countries, even if quitting smoking is higher in developed countries. Positively, the prevalence of smoking decreased over time, but pursing tobacco control is necessary.

Supplementary Materials: The following are available online at https: / www.mdpi.com/article / 10.3390/ijerph182413328/s1: Figure S1, Funnel plots; Figure S2, Meta-analysis on prevalence of ex-smokers among physicians; Figure S3, Comparisons.

Author Contributions: Conceptualization, F.D.; methodology, F.D.; formal analysis, F.D.; investigation, A.T. and A.B. (Amanda Benson); data curation, A.T. and A.B. (Amanda Benson); writingoriginal draft preparation, A.B. (Anaïs Besson) and A.T.; writing-review and editing, V.F., G.B., C.L., V.N., F.D. and J.-B.B.-M.; visualization, F.D.; supervision, F.D. All authors have read and agreed to the published version of the manuscript.

Funding: This research received no external funding.

Institutional Review Board Statement: Not applicable.

Informed Consent Statement: Not applicable.

Data Availability Statement: All relevant data are within the paper.

Acknowledgments: To Nathalie Pinol-Domenech for her availability.

Conflicts of Interest: The authors declare no conflict of interest. 


\section{Appendix A. Details for the Search Strategy Used within Each Database}

Pubmed

"Smoking"[Mesh:NoExp] OR "smokings"[TW] OR "smoking" [TW] OR “Tobacco Smoking"[MH] OR "Smokers"[MH] OR "smoker"[TW] OR "Smokers"[TW] OR "tobacco"[Title]

AND

"family doctor "[TW] OR "general practitioner"[TW] OR “general practitioners"[TW] OR "practitioner, general" [TW] OR “practitioners, general"[TW] OR “general physician" [TW] OR “general physicians"[TW] OR "physicians, family"[TW] OR "family physicians"[TW] OR "family physician" [TW] OR "physician, family"[TW] OR "physicians, primary care"[TW] OR "physician, primary care" [TW] OR "primary care practitioner "[TW] OR "primary care physician" [TW] OR "primary care physicians"[TW] OR "medical practitioner"[TW] OR "physicians" [MH] OR "physicians"[Title] OR "physician"[Title] OR “doctor"[title] OR "doctors"[title] OR "practitioner" [Title] OR "practitioners"[Title]

\section{AND}

"prevalence" $[\mathrm{MH}]$ OR "prevalence"[TW] OR "prevalences"[TW] OR "epidemiology"[MH] OR "episode of care"[TW] OR "epidemiological"[TW] OR "epidemiologic"[TW] OR "epidemiology"[TW] OR “epidemiology" [SH] OR "frequency" [TIAB] OR "morbidity" [TIAB] OR “epidemics"[TIAB] OR “outbreaks"[TIAB] OR “endemics"[TIAB] OR “occurrence"[TIAB] OR “surveillance"[TIAB] OR "incidence" [TIAB]

\section{Embase}

'health personnel attitude' / exp AND ‘smoking/exp AND ‘physician' / exp

\section{Cochrane}

“smokings":ti,ab,kw OR “smoking":ti,ab,kw OR “smoker":ti,ab,kw OR “Smokers”:ti,ab,kw OR tobacco:ti,ab,kw

AND

"physicians, family":ti,ab,kw OR "physicians, primary care":ti,ab,kw OR "family doctor":ti,ab,kw OR “general practitioner":ti,ab,kw OR "general practitioners":ti,ab,kw OR "practitioner, general":ti,ab,kw OR "practitioners, general":ti,ab,kw OR “general physician":ti,ab,kw OR “general physicians":ti,ab,kw OR "physicians, family":ti,ab,kw OR "family physicians":ti,ab,kw OR "family physician":ti,ab,kw OR "physician, family":ti,ab,kw OR "physicians, primary care":ti,ab,kw OR "physician, primary care":ti,ab,kw OR "primary care practitioner ":ti,ab,kw OR “primary care physician":ti,ab,kw OR "primary care physicians":ti,ab,kw OR "physicians":ti,ab,kw OR “doctor":ti,ab,kw OR “doctors":ti,ab,kw OR “medical practitioner"ti,ab,kw OR “physicians":ti,ab,kw OR “physicians":ti OR “physician":ti OR “doctor":ti OR “doctors":ti OR "practitioners":ti OR “practitioner":ti

AND

"prevalence":ti,ab,kw OR "prevalences":ti,ab,kw OR "epidemiology":ti,ab,kw OR "episode of care" :ti,ab,kw OR “epidemiological”:ti,ab,kw OR “epidemiologic":ti,ab,kw OR “frequency":ti,ab,kw OR “morbidity":ti,ab,kw OR “epidemics":ti,ab,kw OR “outbreaks":ti,ab,kw OR “endemics":ti,ab,kw OR "occurrence":ti,ab,kw OR “surveillance":ti,ab,kw

Table A1. Methodological assessment of studies using STROBE and CONSORT criteria.

\begin{tabular}{lccccc}
\hline & \multicolumn{3}{c}{ STROBE } & & \\
& $\begin{array}{c}\text { Total } \\
\text { Score }\end{array}$ & $\begin{array}{c}\text { Abstract } \\
\text { Introduction }\end{array}$ & Methods & Results & Discussion \\
\hline Aaro 1977 & 60 & 100 & 36 & 60 & 75 \\
\hline Abdullah 2006 & 59 & 100 & 69 & 30 & 75 \\
\hline Aboyans 2009 & 56 & 100 & 31 & 50 & 100 \\
\hline
\end{tabular}


Table A1. Cont.

\begin{tabular}{|c|c|c|c|c|c|}
\hline Akvardar 2004 & 53 & 100 & 38 & 40 & 75 \\
\hline Al Alwan 2013 & 50 & 100 & 31 & 40 & 100 \\
\hline Alarjan 2015 & 53 & 100 & 46 & 40 & 75 \\
\hline al-Khateeb 1990 & 38 & 100 & 31 & 30 & 25 \\
\hline Allan 1976 & 13 & 0 & NA & 20 & $\mathrm{NA}$ \\
\hline Al-Lawati 2009 & 44 & 100 & 23 & 20 & 100 \\
\hline Al Shahrani 2021 & 69 & 100 & 69 & 60 & 75 \\
\hline An 2004 & 66 & 100 & 69 & 50 & 75 \\
\hline Amara 2008 & 53 & 100 & 38 & 40 & 100 \\
\hline Amte 2015 & 56 & 100 & 38 & 50 & 100 \\
\hline Arnetz 1988 & 66 & 100 & 54 & 60 & 75 \\
\hline Aryayev 2014 & 48 & 100 & 31 & 33 & 100 \\
\hline Baltaci 2014 & 53 & 100 & 38 & 40 & 75 \\
\hline Baptista 1993 & 44 & 100 & 31 & 30 & 100 \\
\hline Barengo 2004 & 45 & 100 & 42 & 33 & 50 \\
\hline Barengo 2005 & 44 & 100 & 23 & 30 & 100 \\
\hline Barnoya 2002 & 28 & 50 & 0 & 20 & 100 \\
\hline Basnyat 2000 & 34 & 100 & 10 & 20 & 100 \\
\hline Basu 2011 & 47 & 100 & 23 & 40 & 100 \\
\hline Behbehani 2004 & 50 & 100 & 54 & 20 & 75 \\
\hline Belkić 2007 & 59 & 100 & 38 & 50 & 100 \\
\hline Belkić 2012 & 56 & 100 & 54 & 30 & 100 \\
\hline Bener 1993 & 38 & 100 & 15 & 30 & 50 \\
\hline Borgan 2014 & 47 & 100 & 31 & 20 & 100 \\
\hline Bortz 1992 & 29 & 75 & 10 & 30 & 50 \\
\hline Bostan 2015 & 56 & 100 & 46 & 40 & 75 \\
\hline Bourke 1972 & 41 & 100 & 23 & 30 & 50 \\
\hline Braun 2004 & 41 & 100 & 31 & 30 & 25 \\
\hline Brenner 1996 & 56 & 100 & 46 & 40 & 100 \\
\hline Brink 1994 & 53 & 100 & 46 & 50 & 50 \\
\hline Brotonsc 2005 & 53 & 100 & 46 & 30 & 75 \\
\hline Burgess 1970 & 19 & 50 & 10 & 20 & 25 \\
\hline Burgess 1978 & 28 & 75 & 23 & 20 & 50 \\
\hline Cao 2011 & 41 & 50 & 25 & 44 & 75 \\
\hline Carlos 2020 & 70 & 100 & 62 & 60 & 75 \\
\hline Ceraso 2009 & 59 & 100 & 46 & 40 & 100 \\
\hline Chaudhry 2009 & 32 & 100 & 17 & 20 & 50 \\
\hline Cheng 1990 & 45 & 100 & 25 & 40 & 75 \\
\hline Coe 1971 & 34 & 50 & 15 & 30 & 75 \\
\hline Cofta 2008 & 50 & 100 & 38 & 30 & 75 \\
\hline Das 2013 & 53 & 100 & 46 & 30 & 75 \\
\hline Davies 1989 & 47 & 75 & 45 & 40 & 50 \\
\hline
\end{tabular}


Table A1. Cont.

\begin{tabular}{|c|c|c|c|c|c|}
\hline De Col 2010 & 59 & 100 & 54 & 50 & 75 \\
\hline Dekker 1993 & 44 & 100 & 31 & 40 & 50 \\
\hline De Oliveira 2013 & 56 & 100 & 46 & 40 & 100 \\
\hline Desalu 2009 & 47 & 100 & 46 & 30 & 50 \\
\hline Djalalinia 2011 & 47 & 100 & 46 & 20 & 75 \\
\hline Dodds 1979 & 38 & 50 & 38 & 43 & 50 \\
\hline Doll 1954 & 41 & 100 & 31 & 20 & 75 \\
\hline Doll 1964 & 44 & 100 & 38 & 30 & 50 \\
\hline Doll 1994 & 50 & 100 & 31 & 50 & 75 \\
\hline Doll 2004 & 53 & 100 & 31 & 50 & 75 \\
\hline Easton 2001 & 78 & 100 & 77 & 50 & 100 \\
\hline Easton 2001 & 61 & 100 & 54 & 56 & 75 \\
\hline Edwards 2008 & 63 & 75 & 46 & 70 & 75 \\
\hline Edwards 2018 & 66 & 75 & 46 & 70 & 100 \\
\hline Fadhil 2007 & 63 & 100 & 55 & 50 & 75 \\
\hline Fanello 1990 & 56 & 100 & 54 & 50 & 50 \\
\hline Fathi 2016 & 56 & 100 & 46 & 30 & 100 \\
\hline Fowler 1989 & 69 & 100 & 77 & 50 & 75 \\
\hline Franceschi 1986 & 39 & 50 & 31 & 50 & 25 \\
\hline Frank 1998 & 75 & 100 & 77 & 60 & 100 \\
\hline Frank 2009 & 63 & 75 & 54 & 50 & 100 \\
\hline Freour 2011 & 50 & 100 & 38 & 30 & 100 \\
\hline Garfinkel 1976 & 27 & 50 & 23 & 20 & 25 \\
\hline Grossman 1999 & 56 & 100 & 46 & 40 & 75 \\
\hline Gunes 2005 & 60 & 100 & 46 & 50 & 100 \\
\hline Gupta 2013 & 50 & 100 & 46 & 30 & 75 \\
\hline Hallett 1983 & 28 & 75 & 10 & 30 & 50 \\
\hline Hamadeh 1999 & 53 & 100 & 38 & 40 & 75 \\
\hline Han Zao Li 2008 & 56 & 100 & 46 & 40 & 100 \\
\hline Hay 1976 & 41 & 100 & 15 & 40 & 75 \\
\hline Hay 1998 & 53 & 75 & 31 & 60 & 75 \\
\hline Heloma 1998 & 56 & 100 & 46 & 40 & 75 \\
\hline Hensrud 1993 & 53 & 100 & 38 & 50 & 75 \\
\hline Hepburn 2000 & 59 & 100 & 62 & 40 & 75 \\
\hline Heponiemi 2008 & 59 & 100 & 46 & 40 & 100 \\
\hline Hidalgo 2016 & 56 & 100 & 46 & 40 & 75 \\
\hline Hill 1997 & 50 & 100 & 54 & 30 & 50 \\
\hline Hodgetts 2004 & 56 & 100 & 38 & 50 & 100 \\
\hline Hoseainrezae 2013 & 44 & 100 & 38 & 30 & 50 \\
\hline Huang 2013 & 63 & 100 & 46 & 50 & 100 \\
\hline Hughes 1991 & 63 & 100 & 64 & 40 & 75 \\
\hline Hughes 1992 & 63 & 75 & 69 & 40 & 75 \\
\hline
\end{tabular}


Table A1. Cont.

\begin{tabular}{|c|c|c|c|c|c|}
\hline Hughes 1999 & 50 & 100 & 46 & 20 & 100 \\
\hline Hung 2013 & 59 & 100 & 46 & 50 & 100 \\
\hline Hussain 1993 & 41 & 100 & 38 & 30 & 25 \\
\hline Içli 1992 & 34 & 100 & 31 & 20 & 25 \\
\hline Innos 2002 & 52 & 100 & 38 & 44 & 75 \\
\hline Jacot Sadowski 2009 & 73 & 100 & 82 & 50 & 75 \\
\hline Jiang 2007 & 63 & 100 & 69 & 50 & 50 \\
\hline Jiménez-Ruiz 2015 & 56 & 100 & 38 & 40 & 100 \\
\hline Jingi 2015 & 47 & 100 & 38 & 30 & 75 \\
\hline John 2003 & 41 & 100 & 31 & 10 & 75 \\
\hline Joossens 1987 & 38 & 75 & 31 & 40 & 25 \\
\hline Josseran 2000 & 47 & 100 & 46 & 10 & 100 \\
\hline Josseran 2005 & 59 & 100 & 46 & 40 & 100 \\
\hline Julião 2013 & 53 & 100 & 38 & 40 & 100 \\
\hline Kaetsu 2002 & 63 & 100 & 45 & 70 & 75 \\
\hline Kaetsu 2002 & 78 & 100 & 77 & 60 & 75 \\
\hline Kai 2008 & 59 & 100 & 69 & 30 & 75 \\
\hline Kaneita 2010 & 78 & 100 & 77 & 60 & 100 \\
\hline Kawahara 2000 & 70 & 100 & 64 & 50 & 100 \\
\hline Kawakami 1997 & 48 & 75 & 45 & 22 & 75 \\
\hline Kawane 1993 & 50 & 0 & NA & NA & NA \\
\hline Kono 1995 & 78 & 100 & 85 & 60 & 100 \\
\hline Kotz 2007 & 78 & 100 & 77 & 60 & 100 \\
\hline Lam 2011 & 88 & 100 & 92 & 70 & 100 \\
\hline La Vecchia 2000 & 20 & 100 & 15 & 20 & NA \\
\hline Lefcoe 1970 & 52 & 100 & 55 & 22 & 75 \\
\hline Legnini 1987 & 50 & 100 & 46 & 30 & 75 \\
\hline Lindfors 2009 & 66 & 100 & 69 & 40 & 100 \\
\hline Linn 1986 & 56 & 100 & 54 & 50 & 50 \\
\hline Lipp 1972 & 44 & 100 & 31 & 20 & 100 \\
\hline Lipp 1972 & 31 & 75 & 15 & 20 & 75 \\
\hline Magee 2017 & 63 & 100 & 62 & 30 & 100 \\
\hline Malik 2010 & 47 & 100 & 46 & 30 & 50 \\
\hline Manson 2000 & 63 & 100 & 62 & 40 & 100 \\
\hline Mappin-Kasirer 2020 & 63 & 100 & 62 & 50 & 75 \\
\hline Marakoğlu 2006 & 47 & 100 & 38 & 30 & 75 \\
\hline Márk 1998 & 53 & 100 & 46 & 30 & 100 \\
\hline Mathavan 2009 & 63 & 100 & 62 & 40 & 75 \\
\hline McAuliffe 1984 & 41 & 100 & 31 & 30 & 50 \\
\hline McEwen 2001 & 56 & 100 & 46 & 50 & 75 \\
\hline McGrady 2007 & 63 & 100 & 46 & 50 & 100 \\
\hline Mejia 2011 & 54 & 100 & 50 & 33 & 75 \\
\hline
\end{tabular}


Table A1. Cont.

\begin{tabular}{|c|c|c|c|c|c|}
\hline Merrill 2006 & 56 & 100 & 62 & 20 & 100 \\
\hline Meshefedjian 2010 & 59 & 100 & 54 & 40 & 100 \\
\hline Mikalauskas 2012 & 63 & 100 & 54 & 50 & 100 \\
\hline Misra 2004 & 63 & 100 & 62 & 50 & 75 \\
\hline Miwa 1995 & 50 & 100 & 46 & 30 & 75 \\
\hline Mohan 2006 & 50 & 100 & 46 & 40 & 50 \\
\hline Mohseni-Bandpei 2011 & 63 & 100 & 62 & 30 & 100 \\
\hline Moreno 2006 & 24 & 100 & 15 & 30 & 25 \\
\hline Mostafa 2017 & 63 & 100 & 62 & 40 & 100 \\
\hline Movsisyan 2019 & 56 & 100 & 62 & 40 & 50 \\
\hline Mubeen 2008 & 59 & 100 & 46 & 40 & 100 \\
\hline Naji 2006 & 34 & 100 & 15 & 30 & 50 \\
\hline Nakládalová 2005 & 50 & 100 & 38 & 40 & 50 \\
\hline Nardini 1998 & 53 & 100 & 54 & 30 & 50 \\
\hline Nawaz 2007 & 56 & 100 & 62 & 40 & 50 \\
\hline Nawaz 2008 & 44 & 100 & 31 & 30 & 50 \\
\hline Ndiaye 2001 & 56 & 100 & 54 & 50 & 50 \\
\hline Nelson 1994 & 65 & 75 & 77 & 22 & 100 \\
\hline Ng 2007 & 61 & 100 & 62 & 56 & 50 \\
\hline Nollen 2004 & 53 & 100 & 54 & 30 & 75 \\
\hline Nutbeam 1990 & 53 & 100 & 46 & 40 & 50 \\
\hline Obeidat 2017 & 66 & 100 & 54 & 50 & 100 \\
\hline Öztürk 2012 & 59 & 100 & 69 & 50 & 25 \\
\hline O'Cathail 2013 & 63 & 100 & 62 & 40 & 100 \\
\hline Ohida 2001 & 63 & 100 & 54 & 40 & 100 \\
\hline O'Keeffe 2019 & 75 & 100 & 69 & 60 & 100 \\
\hline Pärna 2005 A & 69 & 100 & 69 & 40 & 100 \\
\hline Pärna 2005 B & 66 & 100 & 62 & 40 & 100 \\
\hline Pärna 2017 & 59 & 100 & 46 & 40 & 100 \\
\hline Perrin 2006 & 63 & 100 & 62 & 40 & 100 \\
\hline Peykari 2010 & 59 & 100 & 46 & 40 & 100 \\
\hline Phillips 1968 & 41 & 100 & 31 & 30 & 50 \\
\hline Pillay 2020 & 47 & 50 & 31 & 50 & 50 \\
\hline Pipe 2009 & 59 & 100 & 54 & 30 & 100 \\
\hline Piryani 2004 & 34 & 100 & 15 & 30 & 50 \\
\hline Pizzo 2003 & 47 & 100 & 42 & 30 & 50 \\
\hline Poanta 2006 & 73 & 75 & 77 & 50 & 100 \\
\hline Põld 2017 & 72 & 100 & 69 & 50 & 100 \\
\hline Põld 2020 & 94 & 100 & 92 & 90 & 100 \\
\hline Polyzos 1995 & 38 & 50 & 38 & 40 & 25 \\
\hline Power 1999 & 66 & 100 & 77 & 40 & 75 \\
\hline
\end{tabular}


Table A1. Cont.

\begin{tabular}{|c|c|c|c|c|c|}
\hline Ramachandran 2008 & 70 & 75 & 73 & 50 & 75 \\
\hline Ranchal 2018 & 74 & 100 & 77 & 56 & 100 \\
\hline Rankin 1975 & 44 & 100 & 8 & 50 & 75 \\
\hline Ravara 2014 & 55 & 100 & 31 & 60 & 75 \\
\hline Reile 2018 & 74 & 100 & 46 & 58 & 100 \\
\hline Roche 1995 & 66 & 100 & 62 & 60 & 75 \\
\hline Roche 1996 & 69 & 100 & 77 & 60 & 50 \\
\hline Rurik 2008 & 47 & 100 & 31 & 40 & 75 \\
\hline Rurik 2014 & 41 & 100 & 31 & 30 & 50 \\
\hline Sachs 1983 & 44 & 50 & 67 & 44 & 0 \\
\hline Saeed 1991 & 53 & 75 & 38 & 50 & 75 \\
\hline Saeys 2014 & 81 & 100 & 77 & 70 & 100 \\
\hline Salgado 2014 & 72 & 75 & 69 & 80 & 100 \\
\hline Samuels 1997 & 50 & 75 & 23 & 50 & 100 \\
\hline Schnoll 2006 & 59 & 100 & 62 & 50 & 50 \\
\hline Scott 1992 & 41 & 100 & 23 & 30 & 75 \\
\hline Sebo 2007 & 65 & 100 & 62 & 44 & 100 \\
\hline Seller 1983 & 42 & 50 & 44 & 50 & 25 \\
\hline Senior 1982 & 56 & 100 & 62 & 30 & 75 \\
\hline Sharma 1988 & 24 & 50 & 15 & 17 & 100 \\
\hline Shkedy 2013 & 59 & 100 & 36 & 44 & 100 \\
\hline Shi 2010 & 61 & 100 & 67 & 30 & 100 \\
\hline Shin 2012 & 72 & 100 & 77 & 50 & 100 \\
\hline Shishani 2008 & 75 & 100 & 85 & 40 & 100 \\
\hline Shishani 2011 & 75 & 75 & 85 & 60 & 75 \\
\hline Siddiqui 2001 & 50 & 100 & 46 & 30 & 75 \\
\hline Singh 1981 & 50 & 100 & 38 & 30 & 75 \\
\hline Smith 2006 & 67 & 100 & 64 & 50 & 75 \\
\hline Smith 2007 & 50 & 67 & 50 & 33 & NA \\
\hline Sotiropoulos 2007 & 70 & 100 & 55 & 80 & 75 \\
\hline Squier 2006 & 63 & 100 & 54 & 50 & 100 \\
\hline Steinberg 2007 & 50 & 100 & 46 & 30 & 75 \\
\hline Stuyt 2009 & 55 & 75 & 31 & 56 & 100 \\
\hline Sundquist 1999 & 72 & 100 & 69 & 50 & 100 \\
\hline Svärdsudd 2002 & 69 & 100 & 77 & 50 & 75 \\
\hline Tapia-Conyer 1997 & 66 & 100 & 62 & 50 & 75 \\
\hline Tee 2007 & 69 & 100 & 62 & 60 & 75 \\
\hline Tessier 1996 & 53 & 100 & 38 & 30 & 100 \\
\hline Thankappan 2008 & 56 & 100 & 62 & 40 & 50 \\
\hline Thomas 1986 & 66 & 100 & 54 & 50 & 100 \\
\hline Thomas 1997 & 44 & 100 & 38 & 30 & 50 \\
\hline Tomson 2003 & 56 & 100 & 46 & 30 & 100 \\
\hline
\end{tabular}


Table A1. Cont.

\begin{tabular}{|c|c|c|c|c|c|}
\hline Tong 2010 & 66 & 100 & 62 & 40 & 100 \\
\hline Torre 2005 & 53 & 100 & 38 & 30 & 100 \\
\hline Tosun 2016 & 53 & 100 & 38 & 30 & 100 \\
\hline Trédaniel 1993 & 50 & 100 & 54 & 30 & 50 \\
\hline Ulbricht 2009 & 66 & 100 & 54 & 50 & 100 \\
\hline Unal 2017 & 63 & 100 & 62 & 40 & 75 \\
\hline Underner 2004 & 63 & 50 & 62 & 50 & 100 \\
\hline Underner 2006 & 63 & 75 & 62 & 50 & 75 \\
\hline Uysal 2007 & 69 & 75 & 77 & 60 & 75 \\
\hline Vanderhoek 2013 & 81 & 100 & 77 & 70 & 100 \\
\hline Vanphanom 2011 & 73 & 100 & 85 & 25 & 100 \\
\hline Varona 2005 & 42 & 100 & 30 & 57 & 25 \\
\hline Viegas 2007 & 63 & 75 & 69 & 38 & 75 \\
\hline Voigt 2009 & 63 & 75 & 62 & 56 & 75 \\
\hline Waalkens 1992 & 57 & 75 & 42 & 56 & 75 \\
\hline Wada 2007 & 66 & 100 & 77 & 40 & 50 \\
\hline Wada 2011 & 50 & 100 & 38 & 40 & 75 \\
\hline Wang 2021 & 59 & 75 & 69 & 50 & 50 \\
\hline Wilf Miron 2019 & 59 & 100 & 54 & 50 & 50 \\
\hline Waillaing 2003 & 77 & 100 & 92 & 50 & 100 \\
\hline Wilson 2020 & 69 & 100 & 69 & 60 & 75 \\
\hline Wyshak 1980 & 34 & 50 & 38 & 22 & 25 \\
\hline Yaacob 1993 & 69 & 100 & 62 & 50 & 100 \\
\hline Yan 2008 & 87 & 100 & 100 & 67 & 75 \\
\hline Young 1997 & 56 & 50 & NA & 50 & NA \\
\hline Zabadi 2018 & 81 & 100 & 85 & 56 & 100 \\
\hline Zanetti 1998 & 47 & 75 & 54 & 30 & 50 \\
\hline Zhang 2012 & 56 & 100 & 69 & 40 & 25 \\
\hline Zhang 2015 & 70 & 67 & NA & 67 & NA \\
\hline Zhou 2010 & 35 & 75 & 50 & 60 & 100 \\
\hline Zinonos 2016 & 100 & 100 & 100 & 100 & 100 \\
\hline Zylbersztejn 2015 & 78 & 100 & 85 & 50 & 100 \\
\hline \multicolumn{6}{|c|}{ CONSORT } \\
\hline $\begin{array}{l}\text { Total } \\
\text { Score }\end{array}$ & $\begin{array}{c}\text { Abstract } \\
\text { Introduction }\end{array}$ & Methods & Results & Discussion & Other \\
\hline $\begin{array}{l}\text { Glavas } \\
2003 \\
\end{array}$ & 100 & 59 & 70 & 67 & 33 \\
\hline $\begin{array}{l}\text { Saadat } \\
2012\end{array}$ & 100 & 59 & 80 & 100 & 33 \\
\hline
\end{tabular}


Table A2. Methodological assessment of studies using NOS criteria. NOS for cross-sectional studies.

\begin{tabular}{|c|c|c|c|c|c|c|c|}
\hline & 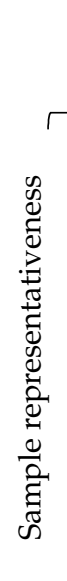 & 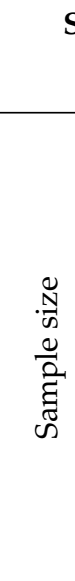 & 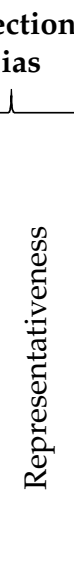 & 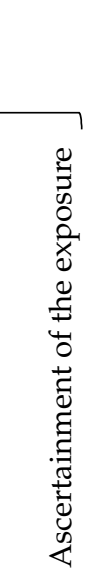 & $\begin{array}{l}\text { Comparability } \\
\text { Bias }\end{array}$ & 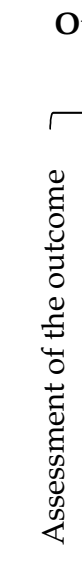 & $\begin{array}{l}\text { ome } \\
\text { is } \\
\end{array}$ \\
\hline Aaro 1977 & + & $\odot$ & $\Theta$ & $?$ & + & + & - \\
\hline Abdullah 2006 & + & $\odot$ & $\Theta$ & + & + & + & + \\
\hline Aboyans 2009 & + & $\odot$ & $\Theta$ & + & + & + & + \\
\hline Akvardar 2004 & + & $\odot$ & $\odot$ & $+\oplus$ & + & + & $?$ \\
\hline Al Alwan 2013 & + & $?$ & + & + & + & + & + \\
\hline Alarjan 2015 & $?$ & - & - & + & + & + & + \\
\hline al-Khateeb 1990 & + & $\odot$ & O & $?$ & - & + & $\Theta$ \\
\hline Allan 1976 & + & - & - & - & - & - & O \\
\hline Al-Lawati 2009 & + & + & $\theta$ & $+\oplus$ & + & + & $?$ \\
\hline Al Shahrani 2021 & + & + & $\Theta$ & $?$ & $?$ & + & + \\
\hline Amara 2008 & + & $\Theta$ & - & + & + & + & $?$ \\
\hline Amte 2015 & + & $\odot$ & $\Theta$ & ++ & + & + & + \\
\hline An 2004 & + & $\Theta$ & O & + & + & + & + \\
\hline Arnetz 1988 & + & $\Theta$ & 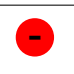 & + & + & + & + \\
\hline Aryayev 2014 & + & $\Theta$ & - & + & + & + & $?$ \\
\hline Baltaci 2014 & & + & $\theta$ & $?$ & + & + & $\Theta$ \\
\hline Baptista 1993 & + & $\Theta$ & - & - & + & + & - \\
\hline Barengo 2004 & + & $\odot$ & O & - & + & + & $\Theta$ \\
\hline Barengo 2005 & $?$ & $\Theta$ & - & $?$ & + & + & - \\
\hline Barnoya 2002 & + & $\odot$ & 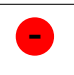 & - & - & + & $\Theta$ \\
\hline Basnyat 2000 & + & $\odot$ & - & + & - & + & - \\
\hline Basu 2011 & $?$ & $\odot$ & $\Theta$ & + & - & + & $\Theta$ \\
\hline Behbehani 2004 & + & + & - & + & - & + & $\odot$ \\
\hline Belkić 2007 & + & $\odot$ & 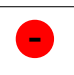 & + & + & + & + \\
\hline
\end{tabular}


Table A2. Cont.

\begin{tabular}{|c|c|c|c|c|c|c|c|}
\hline & 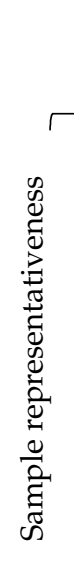 & 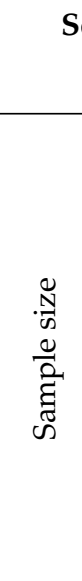 & 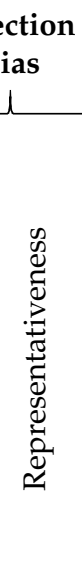 & 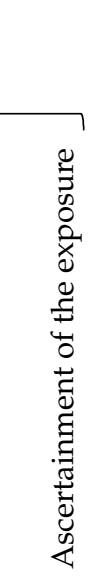 & $\begin{array}{l}\text { Comparability } \\
\text { Bias }\end{array}$ & 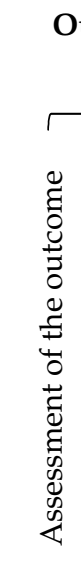 & $\begin{array}{l}\text { ome } \\
\text { is }\end{array}$ \\
\hline Belkić 2012 & $\oplus$ & $\odot$ & $\Theta$ & $+\oplus$ & + & + & + \\
\hline Bener 1993 & + & $\odot$ & $\odot$ & $\odot$ & - & $\odot$ & $\odot$ \\
\hline Borgan 2014 & + & + & $\Theta$ & $?$ & 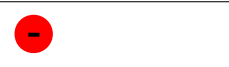 & + & - \\
\hline Bortz 1992 & + & $\odot$ & $\Theta$ & $\odot$ & $\odot$ & $\odot$ & $\odot$ \\
\hline Bostan 2015 & + & $\Theta$ & $\Theta$ & + & + & + & + \\
\hline Bourke 1972 & + & - & $\Theta$ & $?$ & - & + & $\Theta$ \\
\hline Braun 2004 & + & + & $?$ & $\odot$ & + & + & - \\
\hline Brenner 1996 & + & $\Theta$ & & + & $?$ & + & - \\
\hline Brink 1994 & + & $\Theta$ & & + & + & + & - \\
\hline Brotonsc 2005 & + & + & $\Theta$ & $?$ & + & + & $?$ \\
\hline Burgess 1970 & + & $\Theta$ & + & $\odot$ & - & + & $\odot$ \\
\hline Burgess 1978 & + & $\Theta$ & + & O & $\Theta$ & + & $\odot$ \\
\hline Carlos 2020 & + & $\Theta$ & $?$ & + & + & + & + \\
\hline Ceraso 2009 & + & $\odot$ & $\Theta$ & + & + & + & - \\
\hline Chaudhry 2009 & + & $\odot$ & $\Theta$ & $\Theta$ & $\Theta$ & + & $\odot$ \\
\hline Cheng 1990 & $?$ & $\Theta$ & + & - & - & + & - \\
\hline Coe 1971 & + & $\odot$ & $\Theta$ & $\odot$ & - & + & $\odot$ \\
\hline Cofta 2008 & + & $\Theta$ & 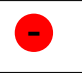 & $\Theta$ & + & + & $\odot$ \\
\hline Das 2013 & + & $?$ & & $?$ & + & + & $\odot$ \\
\hline Davies 1989 & + & $\odot$ & & + & + & + & $\odot$ \\
\hline De Col 2010 & + & ○ & $\Theta$ & $\odot$ & + & + & - \\
\hline Dekker 1993 & + & $\odot$ & $\odot$ & + & - & + & - \\
\hline De Oliveira 2013 & + & $\Theta$ & $\Theta$ & + & + & + & $\odot$ \\
\hline Desalu 2009 & + & + & $\Theta$ & $?$ & 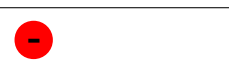 & + & - \\
\hline
\end{tabular}


Table A2. Cont.

\begin{tabular}{|c|c|c|c|c|c|c|c|}
\hline & 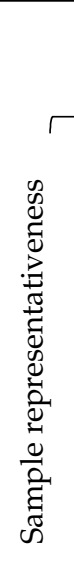 & 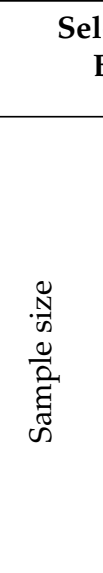 & 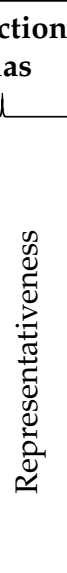 & 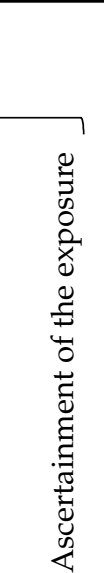 & $\begin{array}{l}\text { Comparability } \\
\text { Bias }\end{array}$ & 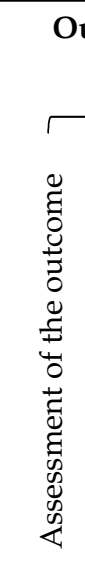 & $\begin{array}{l}\text { ome } \\
\text { ss } \\
\end{array}$ \\
\hline Djalalinia 2011 & $\oplus$ & + & $\odot$ & $+\oplus$ & $\odot$ & + & 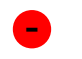 \\
\hline Dodds 1979 & + & $\odot$ & - & + & $\Theta$ & + & - \\
\hline Doll 1954 & + & $\Theta$ & $\Theta$ & + & $\Theta$ & + & $\Theta$ \\
\hline Doll 1964 & + & $\Theta$ & + & + & 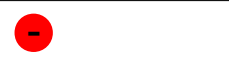 & + & $\Theta$ \\
\hline Doll 1994 & + & $\odot$ & + & + & $?$ & + & $\Theta$ \\
\hline Doll 2004 & + & $\odot$ & + & + & + & + & - \\
\hline Easton 2001 & + & $\odot$ & + & + & + & + & + \\
\hline Easton 2001 & + & + & + & $?$ & + & + & + \\
\hline Edwards 2008 & $\oplus$ & $\oplus$ & + & $+\oplus$ & + & + & + \\
\hline Edwards 2018 & $\oplus$ & + & $\odot$ & + & + & + & + \\
\hline Fadhil 2007 & $\oplus$ & $\odot$ & $\oplus$ & $\odot$ & + & + & + \\
\hline Fanello 1990 & $\oplus$ & $\odot$ & + & + & + & + & + \\
\hline Fathi 2016 & + & + & - & $+\oplus$ & + & + & + \\
\hline Fowler 1989 & + & $\Theta$ & $\Theta$ & + & $?$ & + & + \\
\hline Franceschi 1986 & $?$ & $\oplus$ & $\Theta$ & $?$ & + & + & + \\
\hline Frank 1998 & + & $+\oplus$ & + & $+\oplus$ & + & + & + \\
\hline Frank 2009 & + & + & + & $+\oplus$ & + & + & + \\
\hline Freour 2011 & + & $\Theta$ & - & + & + & + & $?$ \\
\hline Garfinkel 1976 & + & - & $\Theta$ & - & - & + & $\theta$ \\
\hline Grossman 1999 & $?$ & $\odot$ & + & $?$ & $\oplus$ & + & $\Theta$ \\
\hline Gunes 2005 & + & $\Theta$ & $\Theta$ & $+\oplus$ & + & + & + \\
\hline Gupta 2013 & + & - & $\Theta$ & + & + & + & $\odot$ \\
\hline Hallett 1983 & + & $\Theta$ & - & $\Theta$ & - & + & $\Theta$ \\
\hline Hamadeh 1999 & + & $\Theta$ & $\Theta$ & ++ & + & + & - \\
\hline
\end{tabular}


Table A2. Cont.

\begin{tabular}{|c|c|c|c|c|c|c|c|}
\hline & 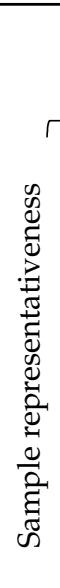 & 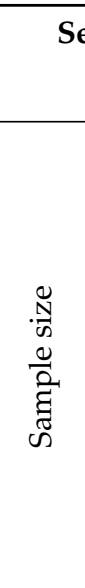 & 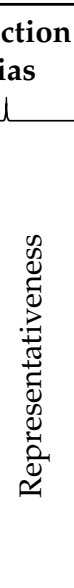 & 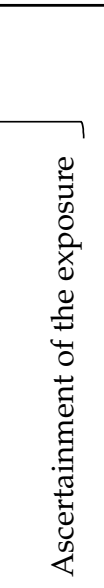 & $\begin{array}{l}\text { Comparability } \\
\text { Bias }\end{array}$ & 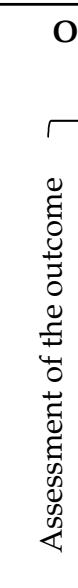 & $\begin{array}{l}\text { me } \\
5 \\
\end{array}$ \\
\hline Han Zao Li 2008 & $?$ & $\Theta$ & $\Theta$ & + & $\oplus$ & + & - \\
\hline Hay 1976 & $\oplus$ & $\odot$ & - & + & + & + & - \\
\hline Hay 1998 & + & + & - & + & + & + & C \\
\hline Heloma 1998 & $\oplus$ & $\Theta$ & $\odot$ & + & + & + & $\odot$ \\
\hline Hensrud 1993 & + & $\Theta$ & $?$ & $?$ & + & + & - \\
\hline Hepburn 2000 & $\oplus$ & $\odot$ & $\Theta$ & + & $\oplus$ & $\oplus$ & + \\
\hline Heponiemi 2008 & $\oplus$ & $\odot$ & + & + & + & + & $?$ \\
\hline Hidalgo 2016 & $\oplus$ & $\odot$ & $\odot$ & + & + & + & $\odot$ \\
\hline Hill 1997 & + & $\odot$ & $\odot$ & + & + & + & + \\
\hline Hodgetts 2004 & + & - & + & + & + & + & $\Theta$ \\
\hline Hoseainrezae 2013 & + & $\odot$ & $\odot$ & + & $\odot$ & + & $\odot$ \\
\hline Huang 2013 & + & $\Theta$ & $\Theta$ & + & + & + & - \\
\hline Hughes 1991 & 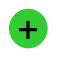 & + & $\odot$ & + & + & + & + \\
\hline Hughes 1992 & + & + & $\odot$ & $+\oplus$ & + & + & + \\
\hline Hughes 1999 & $\oplus$ & $\Theta$ & $\Theta$ & + & + & + & + \\
\hline Hung 2013 & $\oplus$ & $\Theta$ & $?$ & + & $+\oplus$ & + & + \\
\hline Hussain 1993 & $\oplus$ & $\odot$ & $\Theta$ & + & $\odot$ & + & $\odot$ \\
\hline Içli 1992 & + & $\ominus$ & $\Theta$ & + & - & + & $\odot$ \\
\hline Jacot Sadowski 2009 & + & $\odot$ & $\odot$ & + & + & + & + \\
\hline Jiang 2007 & + & + & 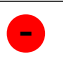 & ++ & + & + & + \\
\hline Jiménez-Ruiz 2015 & $?$ & $\odot$ & $\odot$ & + & + & + & $?$ \\
\hline Jingi 2015 & + & $\Theta$ & - & + & - & + & + \\
\hline John 2003 & + & $\Theta$ & $\Theta$ & + & $\Theta$ & + & - \\
\hline
\end{tabular}


Table A2. Cont.

\begin{tabular}{|c|c|c|c|c|c|c|c|}
\hline & 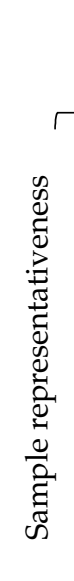 & 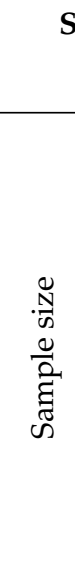 & 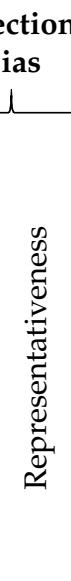 & 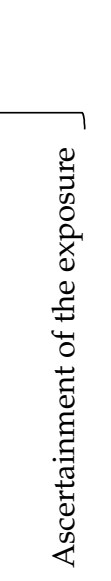 & $\begin{array}{l}\text { Comparability } \\
\text { Bias }\end{array}$ & 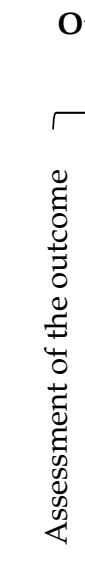 & 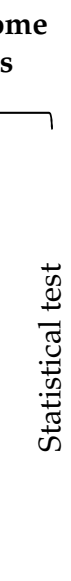 \\
\hline Joossens 1987 & + & $\odot$ & $\Theta$ & + & - & + & $\odot$ \\
\hline Josseran 2000 & + & $\odot$ & - & + & + & + & $\odot$ \\
\hline Josseran 2005 & + & $\odot$ & $\Theta$ & + & + & + & + \\
\hline Julião 2013 & + & $\odot$ & $\Theta$ & + & + & + & $\odot$ \\
\hline Kaetsu 2002 & + & + & - & + & + & + & + \\
\hline Kai 2008 & + & - & - & + & - & + & + \\
\hline Kaneita 2010 & + & + & - & ++ & + & + & + \\
\hline Kawahara 2000 & + & $?$ & 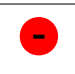 & + & + & + & + \\
\hline Kawakami 1997 & + & + & - & + & + & + & + \\
\hline Kawane 1993 & + & - & 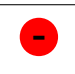 & - & $\odot$ & - & - \\
\hline Kotz 2007 & + & + & $?$ & $?$ & + & + & + \\
\hline Lam 2011 & + & + & + & ++ & + & + & + \\
\hline La Vecchia 2000 & + & - & - & + & - & + & $\odot$ \\
\hline Lefcoe 1970 & + & + & - & + & $?$ & + & + \\
\hline Legnini 1987 & + & + & - & + & - & + & - \\
\hline Lindfors 2009 & + & $\Theta$ & $\odot$ & + & + & + & + \\
\hline Linn 1986 & + & - & - & + & + & + & - \\
\hline Lipp 1972 & + & $\Theta$ & 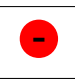 & + & 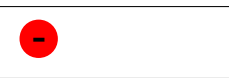 & + & - \\
\hline Lipp 1972 & + & $\Theta$ & - & + & - & + & - \\
\hline Magee 2017 & + & - & - & $\oplus$ & + & + & $\oplus$ \\
\hline Malik 2010 & + & - & - & ++ & - & + & ○ \\
\hline Marakoğlu 2006 & + & - & - & ++ & 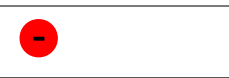 & + & $\Theta$ \\
\hline Márk 1998 & + & $\Theta$ & $\Theta$ & $?$ & - & + & $\odot$ \\
\hline
\end{tabular}


Table A2. Cont.

\begin{tabular}{|c|c|c|c|c|c|c|c|}
\hline & 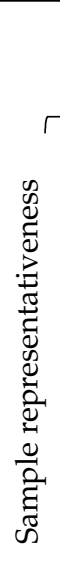 & 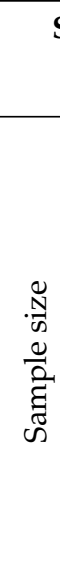 & 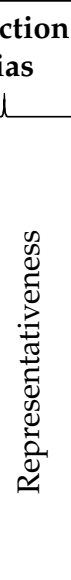 & 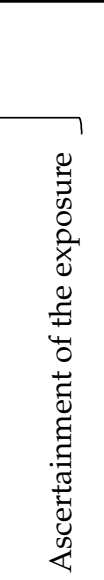 & $\begin{array}{l}\text { Comparability } \\
\text { Bias }\end{array}$ & 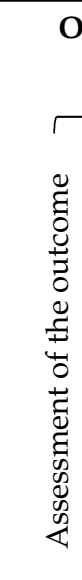 & me \\
\hline Mathavan 2009 & + & - & $\odot$ & $+\oplus$ & + & + & - \\
\hline McAuliffe 1984 & + & 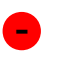 & $\odot$ & + & - & + & 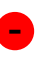 \\
\hline McEwen & + & - & $\Theta$ & + & + & + & $\mathcal{O}$ \\
\hline McGrady 2007 & + & - & + & + & + & + & $?$ \\
\hline Mejia 2011 & + & - & $\odot$ & + & + & + & + \\
\hline Merrill 2006 & + & $\odot$ & $\odot$ & $+\oplus$ & + & + & $\odot$ \\
\hline Meshefedjian 2010 & + & - & $\odot$ & $?$ & + & $\oplus$ & + \\
\hline Mikalauskas 2012 & + & - & $\odot$ & + & + & $\oplus$ & + \\
\hline Misra 2004 & + & - & + & + & + & + & 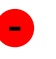 \\
\hline Miwa 1995 & + & ? & $\odot$ & + & + & + & + \\
\hline Mohan 2006 & + & - & $\odot$ & + & + & + & + \\
\hline Mohseni-Bandpei 2011 & + & $\odot$ & 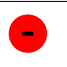 & + & $?$ & + & + \\
\hline Moreno 2006 & + & - & $\odot$ & + & - & + & - \\
\hline Mostafa 2017 & + & + & $\odot$ & $?$ & + & + & $?$ \\
\hline Movsisyan 2019 & + & - & $?$ & + & + & + & + \\
\hline Mubeen 2008 & + & 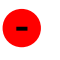 & $\odot$ & + & + & + & - \\
\hline Naji 2006 & + & - & 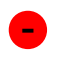 & + & - & + & $\odot$ \\
\hline Nakládalová 2005 & + & - & $\odot$ & + & + & + & - \\
\hline Nardini 1998 & + & - & $\odot$ & + & + & + & - \\
\hline Nawaz 2007 & + & - & $\odot$ & $+\oplus$ & + & + & + \\
\hline Nawaz 2008 & + & - & 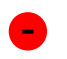 & $?$ & - & + & - \\
\hline Ndiaye 2001 & + & - & $\odot$ & + & + & + & + \\
\hline Nelson 1994 & + & - & $\odot$ & $+\oplus$ & + & + & + \\
\hline
\end{tabular}


Table A2. Cont.

\begin{tabular}{|c|c|c|c|c|c|c|c|}
\hline & 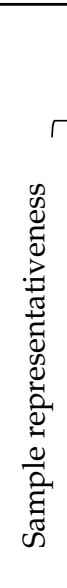 & 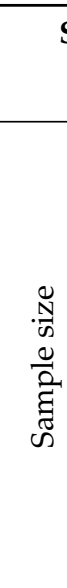 & 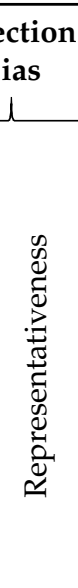 & 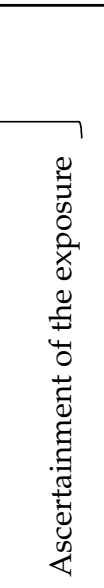 & $\begin{array}{l}\text { Comparability } \\
\text { Bias }\end{array}$ & 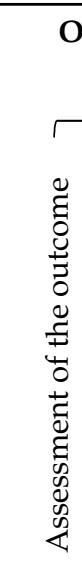 & $\begin{array}{l}\text { ome } \\
\text { is } \\
\end{array}$ \\
\hline Ng 2007 & + & $\odot$ & - & $\oplus$ & + & + & + \\
\hline Nollen 2004 & + & $\odot$ & $\odot$ & + & $\odot$ & + & + \\
\hline Nutbeam 1990 & $?$ & 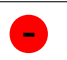 & - & + & $\theta$ & + & $\Theta$ \\
\hline Obeidat 2017 & + & $\odot$ & + & $?$ & + & + & + \\
\hline Öztürk 2012 & + & $\odot$ & - & - & + & + & + \\
\hline O'Cathail 2013 & $\oplus$ & $\odot$ & - & $\oplus$ & + & + & + \\
\hline Ohida 2001 & + & + & - & + & + & $\oplus$ & + \\
\hline O'Keeffe 2019 & + & + & $\Theta$ & + & + & $\oplus$ & + \\
\hline Pärna 2005 A & + & + & - & ++ & + & + & + \\
\hline Pärna 2005 B & + & $\odot$ & - & + & + & + & + \\
\hline Pärna 2017 & + & $\Theta$ & $\Theta$ & + & + & + & + \\
\hline Perrin 2006 & + & $\odot$ & 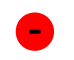 & $+\oplus$ & + & $\oplus$ & + \\
\hline Peykari 2010 & + & $\odot$ & - & $+\oplus$ & + & + & + \\
\hline Phillips 1968 & + & - & $\Theta$ & + & $\Theta$ & + & - \\
\hline Pillay 2020 & + & - & - & + & $\odot$ & + & + \\
\hline Pipe 2009 & + & - & $\odot$ & + & $?$ & + & $?$ \\
\hline Piryani 2004 & + & $\Theta$ & 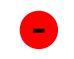 & - & - & + & 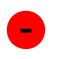 \\
\hline Pizzo 2003 & + & $\odot$ & - & + & + & + & + \\
\hline Poanta 2006 & + & + & - & ++ & + & + & + \\
\hline Põld 2017 & + & + & - & $+\oplus$ & + & + & + \\
\hline Põld 2020 & + & + & + & + & + & + & + \\
\hline Polyzos 1995 & + & - & $\Theta$ & + & $\odot$ & + & $\odot$ \\
\hline Power 1999 & + & - & - & + & + & + & $\oplus$ \\
\hline
\end{tabular}


Table A2. Cont.

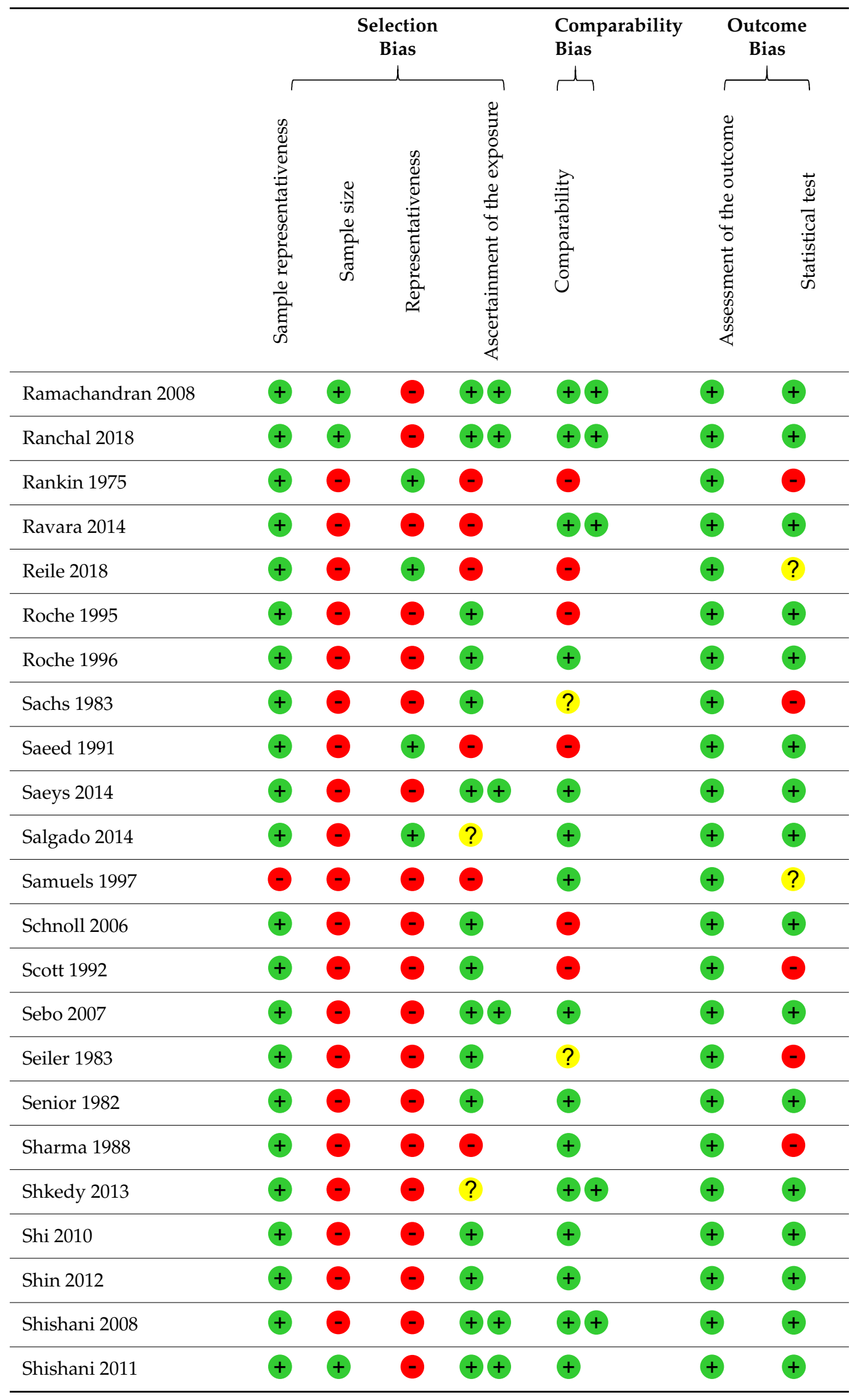


Table A2. Cont.

\begin{tabular}{|c|c|c|c|c|c|c|c|}
\hline & 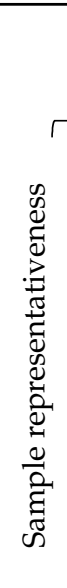 & 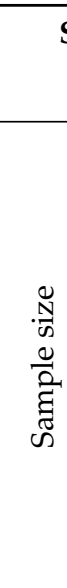 & 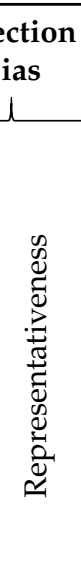 & 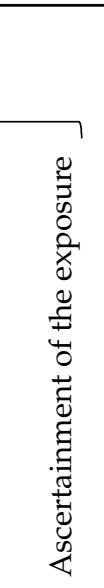 & $\begin{array}{l}\text { Comparability } \\
\text { Bias }\end{array}$ & 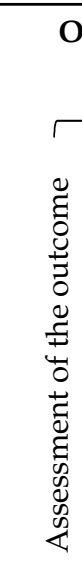 & 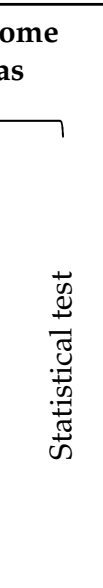 \\
\hline Siddiqui 2001 & + & $\odot$ & $\Theta$ & $\oplus$ & - & + & + \\
\hline Singh 1981 & + & $\odot$ & $\Theta$ & + & - & + & $\Theta$ \\
\hline Smith 2006 & + & 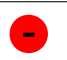 & $\Theta$ & $+\varphi$ & + & + & + \\
\hline Smith 2007 & + & $\odot$ & $\Theta$ & $\Theta$ & + & + & $\Theta$ \\
\hline Sotiropoulos 2007 & + & $\odot$ & $\Theta$ & $?$ & ++ & + & + \\
\hline Squier 2006 & $\oplus$ & $\odot$ & $\Theta$ & $+\oplus$ & + & + & + \\
\hline Steinberg 2007 & + & $\odot$ & $\Theta$ & + & + & $\oplus$ & + \\
\hline Stuyt 2009 & + & $\odot$ & $\odot$ & - & $?$ & $\oplus$ & + \\
\hline Sundquist 1999 & + & $\odot$ & $\odot$ & ++ & + & + & + \\
\hline Tapia-Conyer 1997 & + & + & $\Theta$ & $+\oplus$ & + & + & + \\
\hline Tee 2007 & + & $\Theta$ & $\Theta$ & $+\oplus$ & + & + & + \\
\hline Tessier 1996 & + & 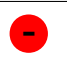 & $\Theta$ & $+\oplus$ & + & + & - \\
\hline Thankappan 2008 & + & - & $\odot$ & + & + & + & + \\
\hline Thomas 1986 & + & + & $\Theta$ & $+\oplus$ & + & + & + \\
\hline Tomson 2003 & + & $?$ & $\Theta$ & + & + & + & $\Theta$ \\
\hline Tong 2010 & + & $\Theta$ & $\Theta$ & $+\varphi$ & + & + & + \\
\hline Tosun 2016 & + & 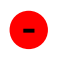 & $\Theta$ & + & + & + & $?$ \\
\hline Trédaniel 1993 & + & - & $\odot$ & + & + & + & + \\
\hline Ulbricht 2009 & + & $\odot$ & $\odot$ & $+\oplus$ & + & + & + \\
\hline Underner 2004 & + & + & $\Theta$ & + & + & + & $+\oplus$ \\
\hline Underner 2006 & & + & $\odot$ & + & $+\oplus$ & + & $+\oplus$ \\
\hline Uysal 2007 & $?$ & $\odot$ & + & - & + & + & + \\
\hline Vanderhoek 2013 & + & $\odot$ & + & $+\oplus$ & + & + & + \\
\hline
\end{tabular}


Table A2. Cont.

\begin{tabular}{|c|c|c|c|c|c|c|c|}
\hline & 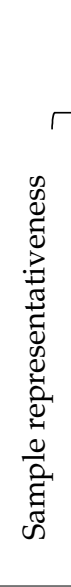 & 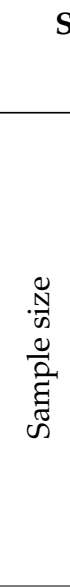 & 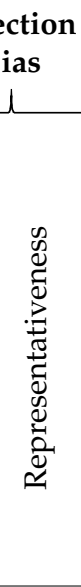 & 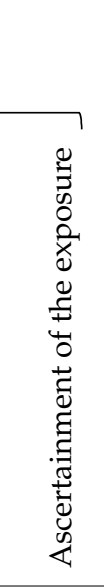 & $\begin{array}{l}\text { Comparability } \\
\text { Bias }\end{array}$ & 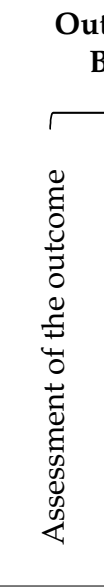 & $\begin{array}{l}\text { ome } \\
\text { as } \\
\end{array}$ \\
\hline Vanphanom 2011 & + & + & + & + & + & + & $?$ \\
\hline Varona 2005 & + & $\odot$ & $\odot$ & $\odot$ & $\odot$ & + & + \\
\hline Viegas 2007 & $\oplus$ & $\oplus$ & $\odot$ & $\oplus$ & + & $\oplus$ & + \\
\hline Voigt 2009 & + & $\odot$ & $\odot$ & ++ & + & + & + \\
\hline Waalkens 1992 & + & $?$ & $\odot$ & - & + & + & + \\
\hline Wada 2007 & + & $\odot$ & $\odot$ & $\oplus$ & + & + & + \\
\hline Wada 2011 & + & - & - & + & + & + & O \\
\hline Wang 2021 & + & + & $\Theta$ & $?$ & $?$ & + & + \\
\hline Wilf Miron 2019 & + & $\odot$ & $\odot$ & + & + & + & $?$ \\
\hline Willaing 2003 & + & $\Theta$ & $\odot$ & + & + & + & + \\
\hline Wilson 2020 & + & $\odot$ & $?$ & + & + & + & + \\
\hline Wyshak 1980 & + & + & $?$ & $\odot$ & $\Theta$ & + & $\odot$ \\
\hline Yaacob 1993 & $\oplus$ & $\oplus$ & + & $\oplus$ & $+\oplus$ & $\oplus$ & $\Theta$ \\
\hline Yan 2008 & + & + & + & ++ & + & ++ & + \\
\hline Young 1997 & $\Theta$ & + & $\odot$ & - & + & + & - \\
\hline Zabadi 2018 & + & + & + & $?$ & $+\oplus$ & $+\oplus$ & + \\
\hline Zanetti 1998 & + & $\Theta$ & $\odot$ & + & + & + & - \\
\hline Zhang 2012 & + & 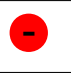 & $\odot$ & + & - & + & + \\
\hline Zhang 2015 & & + & $\odot$ & $\odot$ & - & + & - \\
\hline Zhou 2010 & + & $\Theta$ & $\Theta$ & $+\oplus$ & + & + & + \\
\hline Zinonos 2016 & + & $\odot$ & $?$ & + & + & + & + \\
\hline Zylbersztejn 2015 & $\oplus$ & $?$ & $\odot$ & + & + & + & + \\
\hline
\end{tabular}




\section{Appendix B}

Table A3. NOS for cohort studies.

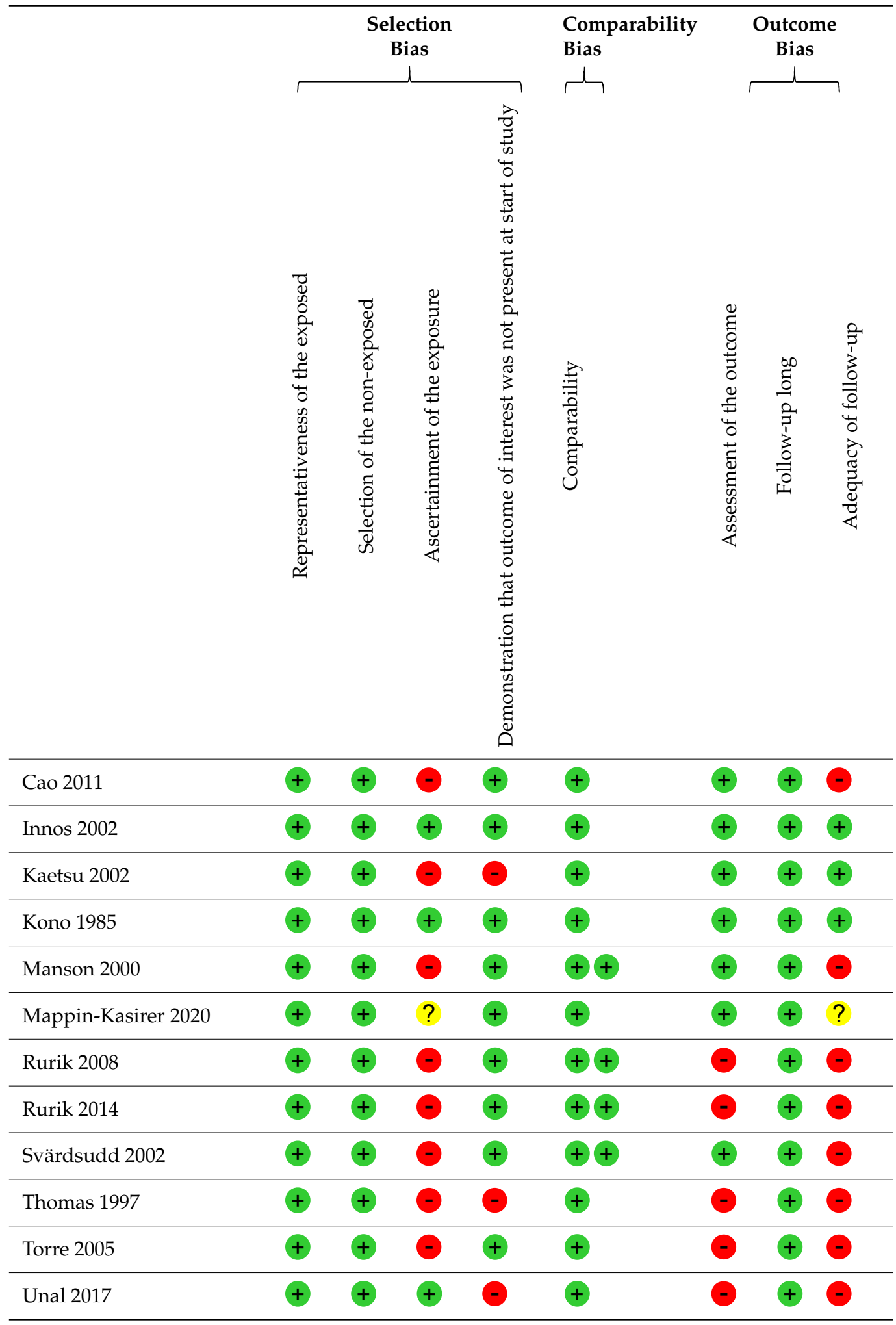




\section{References}

1. World Health Organization. Bloomberg Philanthropies. In WHO Report on the Global Tobacco Epidemic, 2017: Monitoring Tobacco Use and Prevention Policies; WHO: Geneva, Switzerland, 2017; ISBN 978-92-4-151282-4.

2. World Health Organization. Regional Office for the Eastern Mediterranean List of Basic Sources in English for a Medical Faculty Library; WHO: Geneva, Switzerland, 2013.

3. Razzak, H.A.; Harbi, A.; Ahli, S. Tobacco Smoking Prevalence, Health Risk, and Cessation in the UAE. Oman Med. J. 2020, 35 , e165. [CrossRef]

4. Abdullah, A.S.; Qiming, F.; Pun, V.; Stillman, F.A.; Samet, J.M. A Review of Tobacco Smoking and Smoking Cessation Practices among Physicians in China: 1987-2010. Tob. Control 2013, 22, 9-14. [CrossRef]

5. Smith, D.R.; Leggat, P.A. An International Review of Tobacco Smoking in the Medical Profession: 1974-2004. BMC Public Health 2007, 7, 115. [CrossRef]

6. Tong, E.K.; Wolf, T.; Cooke, D.T.; Fairman, N.; Chen, M.S. The Emergence of a Sustainable Tobacco Treatment Program across the Cancer Care Continuum: A Systems Approach for Implementation at the University of California Davis Comprehensive Cancer Center. Int. J. Environ. Res. Public. Health 2020, 17, 3241. [CrossRef]

7. Barengo, N.C.; Sandström, H.P.; Jormanainen, V.J.; Myllykangas, M.T. Attitudes and Behaviours in Smoking Cessation among General Practitioners in Finland 2001. Soz. Praventivmed. 2005, 50, 355-360. [CrossRef]

8. Behbehani, N.; Hamadeh, R.R.; Macklai, N.S. Knowledge of and Attitudes towards Tobacco Control among Smoking and Non-Smoking Physicians in 2 Gulf Arab States. Saudi Med. J. 2004, 25, 585-591. [PubMed]

9. Bouillon-Minois, J.-B.; Trousselard, M.; Pereira, B.; Schmidt, J.; Clinchamps, M.; Thivel, D.; Ugbolue, U.C.; Moustafa, F.; Occelli, C.; Vallet, G.; et al. Protocol of the Study on Emergency Health Care Workers' Responses Evaluated by Karasek Questionnaire: The SEEK-Study Protocol. Int. J. Environ. Res. Public. Health 2021, 18, 4068. [CrossRef]

10. Bouillon-Minois, J.-B.; Raconnat, J.; Clinchamps, M.; Schmidt, J.; Dutheil, F. Emergency Department and Overcrowding during COVID-19 Outbreak; a Letter to Editor. Arch. Acad. Emerg. Med. 2021, 9, e28. [CrossRef] [PubMed]

11. Wainwright, K.; Perrotte, J.K.; Bibriescas, N.; Baumann, M.R.; Garza, R.T. Smoking Expectancies and Health Perceptions: An Analysis of Hispanic Subgroups. Addict. Behav. 2019, 98, 106008. [CrossRef] [PubMed]

12. Ghadban, R.; Haddad, L.; Thacker, L.R.; An, K.; Balster, R.L.; Salyer, J. Smoking Behaviors in Arab Americans: Acculturation and Health Beliefs. J. Transcult. Nurs. Off. J. Transcult. Nurs. Soc. 2019, 30, 115-123. [CrossRef]

13. Musk, A.W.; de Klerk, N.H. History of Tobacco and Health. Respirology 2003, 8, 286-290. [CrossRef] [PubMed]

14. Mounach, S.; Zahrou, F.-E.; Mahdaoui, E.; Belakhel, L.; Khazraji, Y.C.; El Berri, H. Evolution of Attitudes, Trends and Perceptions of Smoking among Middle and Secondary School Students in the Gharb Region, Morocco, 2010-2015. Afr. J. Prim. Health Care Fam. Med. 2019, 11, e1-e6. [CrossRef] [PubMed]

15. Moher, D.; Liberati, A.; Tetzlaff, J.; Altman, D.G.; PRISMA Group. Preferred Reporting Items for Systematic Reviews and Meta-Analyses: The PRISMA Statement. BMJ 2009, 339, b2535. [CrossRef]

16. Stang, A. Critical Evaluation of the Newcastle-Ottawa Scale for the Assessment of the Quality of Nonrandomized Studies in Meta-Analyses. Eur. J. Epidemiol. 2010, 25, 603-605. [CrossRef] [PubMed]

17. Vandenbroucke, J.P. Strengthening the Reporting of Observational Studies in Epidemiology (STROBE): Explanation and Elaboration. Ann. Intern. Med. 2007, 147, 573-578. [CrossRef]

18. Schulz, K.F.; Altman, D.G.; Moher, D. For the CONSORT Group CONSORT 2010 Statement: Updated Guidelines for Reporting Parallel Group Randomised Trials. BMJ 2010, 340, c332. [CrossRef]

19. DerSimonian, R.; Laird, N. Meta-Analysis in Clinical Trials. Control. Clin. Trials 1986, 7, 177-188. [CrossRef]

20. Thorlund, K.; Imberger, G.; Johnston, B.C.; Walsh, M.; Awad, T.; Thabane, L.; Gluud, C.; Devereaux, P.J.; Wetterslev, J. Evolution of Heterogeneity (I2) Estimates and Their 95\% Confidence Intervals in Large Meta-Analyses. PLoS ONE 2012, 7, e39471. [CrossRef]

21. Mostafa, N.; Momen, M. Effect of Physicians' Smoking Status on Their Knowledge, Attitude, Opinions and Practices of Smoking Cessation in a University Hospital, in Egypt. J. Egypt. Public Health Assoc. 2017, 92, 96-106. [CrossRef]

22. Amte, R.; Munta, K.; Gopal, P.B. Stress Levels of Critical Care Doctors in India: A National Survey. Indian J. Crit. Care Med. Peer-Rev. Off. Publ. Indian Soc. Crit. Care Med. 2015, 19, 257-264. [CrossRef]

23. Arnetz, B.B.; Andreasson, S.; Strandberg, M.; Eneroth, P.; Kallner, A. Comparison between Surgeons and General Practitioners with Respect to Cardiovascular and Psychosocial Risk Factors among Physicians. Scand. J. Work. Environ. Health 1988, 14, 118-124. [CrossRef] [PubMed]

24. Nawaz, H.; Imam, S.Z.; Zubairi, A.B.S.; Pabaney, A.H.; Sepah, Y.J.; Islam, M.; Khan, J.A. Smoking Habits and Beliefs of Future Physicians of Pakistan. Int. J. Tuberc. Lung Dis. Off. J. Int. Union Tuberc. Lung Dis. 2007, 11, 915-919.

25. Braun, B.L.; Fowles, J.B.; Solberg, L.I.; Kind, E.A.; Lando, H.; Pine, D. Smoking-Related Attitudes and Clinical Practices of Medical Personnel in Minnesota. Am. J. Prev. Med. 2004, 27, 316-322. [CrossRef]

26. Cheng, K.K.; Lam, T.H. Smoking among Young Doctors in Hong Kong: A Message to Medical Educators. Med. Educ. 1990, 24, 158-163. [CrossRef]

27. Aaro, L.E.; Bjartveit, K.; Vellar, O.D.; Berglund, E.L. Smoking Habits among Norwegian Doctors 1974. Scand. J. Soc. Med. 1977, 5, 127-135. [CrossRef]

28. Aboyans, V.; Pinet, P.; Lacroix, P.; Laskar, M. Knowledge and Management of Smoking-Cessation Strategies among Cardiologists in France: A Nationwide Survey. Arch. Cardiovasc. Dis. 2009, 102, 193-199. [CrossRef] [PubMed] 
29. Akvardar, Y.; Demiral, Y.; Ergor, G.; Ergor, A. Substance Use among Medical Students and Physicians in a Medical School in Turkey. Soc. Psychiatry Psychiatr. Epidemiol. 2004, 39, 502-506. [CrossRef]

30. Al Alwan, I.; Badri, M.; Al-Ghamdi, M.; Aljarbou, A.; Alotaibi, H.; Tamim, H. Prevalence of Self-Reported Cardiovascular Risk Factors among Saudi Physicians: A Comparative Study. Int. J. Health Sci. 2013, 7, 3-13. [CrossRef] [PubMed]

31. Alarjan, J.F.; Hindawi, O.S.; Judge, L.W.; Aleyadh, Z.A.; Bellar, D.M. Prevalence of Obesity and Behaviors Associated with the Development of Metabolic Disease among Medical Practitioners in Jordan. J. Educ. Health Promot. 2015, 4, 17. [CrossRef]

32. Al-Khateeb, M. Trends of Tobacco Smoking among Physicians, Journalists and Teachers in Bahrain. Hygie 1990, 9, $13-15$.

33. Al-Lawati, J.A.; Nooyi, S.C.; Al-Lawati, A.M. Knowledge, Attitudes and Prevalence of Tobacco Use among Physicians and Dentists in Oman. Ann. Saudi Med. 2009, 29, 128-131. [CrossRef] [PubMed]

34. Letter, A.J. Doctors' Smoking Habits. Med. J. Aust. 1976, 1, 71.

35. Aryayev, M.; Lowe, J.B.; Kuzmenko, T. The Prevalence of and Knowledge about Tobacco Use among Physicians in the Odessa Region, Ukraine. Eur. J. Public Health 2014, 24, 474-476. [CrossRef]

36. Baltaci, D.; Bahcebasi, T.; Aydin, L.Y.; Ozturk, S.; Set, T.; Eroz, R.; Celer, A.; Kara, I.H. Evaluation of Smoking Habits among Turkish Family Physicians. Toxicol. Ind. Health 2014, 30, 3-11. [CrossRef]

37. Baptista, T.; Uzcàtegui, E. Substance Use among Resident Doctors in Venezuela. Drug Alcohol Depend. 1993, 32, 127-132. [CrossRef]

38. Barengo, N.C.; Sandström, P.H.; Jormanainen, V.J.; Myllykangas, M.T. Changes in Smoking Prevalence among Finnish Physicians 1990-2001. Eur. J. Public Health 2004, 14, 201-203. [CrossRef]

39. Barnoya, J.; Glantz, S. Knowledge and Use of Tobacco among Guatemalan Physicians. Cancer Causes Control 2002, 13, 879-881. [PubMed]

40. Basnyat, P.S.; Moseley, L.G.; al-Rawi, M.; Galland, R.B.; Lewis, M.H. Smoking—Do Vascular Surgeons Practise What They Preach? Ann. R. Coll. Surg. Engl. 2000, 82, 424-427. [PubMed]

41. Basu, M.; Das, P.; Mitra, S.; Ghosh, S.; Pal, R.; Bagchi, S. Role of Family and Peers in the Initiation and Continuation of Smoking Behavior of Future Physicians. J. Pharm. Bioallied Sci. 2011, 3, 407-411. [CrossRef]

42. Belkić, K.; Nedic, O. Workplace Stressors and Lifestyle-Related Cancer Risk Factors among Female Physicians: Assessment Using the Occupational Stress Index. J. Occup. Health 2007, 49, 61-71. [CrossRef]

43. Belkić, K.; Nedić, O. Night Work, Total Occupational Burden and Cancer/Cardiovascular Risk Factors in Physicians. Med. Pregl. 2012, 65, 461-469. [CrossRef] [PubMed]

44. Bener, A.; Gomes, J.; Anderson, J.A. Smoking Habits among Physicians in Two Gulf Countries. J. R. Soc. Health 1993, 113, $298-301$. [CrossRef] [PubMed]

45. Borgan, S.M.; Jassim, G.; Marhoon, Z.A.; Almuqamam, M.A.; Ebrahim, M.A.; Soliman, P.A. Prevalence of Tobacco Smoking among Health-Care Physicians in Bahrain. BMC Public Health 2014, 14, 931. [CrossRef] [PubMed]

46. Bortz, W.M. Health Behavior and Experiences of Physicians. Results of a Survey of Palo Alto Medical Clinic Physicians. West. J. Med. 1992, 156, 50-51. [PubMed]

47. Bostan, P.P.; Demir, C.K.; Elbek, O.; Akçay, Ş. Association between Pulmonologists' Tobacco Use and Their Effort in Promoting Smoking Cessation in Turkey: A Cross-Sectional Study. BMC Pulm. Med. 2015, 15, 143. [CrossRef]

48. Bourke, G.J.; Wilson-Davis, K.; Thornes, D. Smoking Habits of the Medical Profession in the Republic of Ireland. Am. J. Public Health 1972, 62, 575-580. [CrossRef] [PubMed]

49. Brenner, H.; Scharrer, S. Smoking Habits of Future Physicians: A Survey among Medical Students of a South German University. Soz. Praventivmed. 1996, 41, 150-157. [CrossRef]

50. Brotons, C.; Björkelund, C.; Bulc, M.; Ciurana, R.; Godycki-Cwirko, M.; Jurgova, E.; Kloppe, P.; Lionis, C.; Mierzecki, A.; Piñeiro, R.; et al. Prevention and Health Promotion in Clinical Practice: The Views of General Practitioners in Europe. Prev. Med. 2005, 40, 595-601. [CrossRef]

51. Burgess, A.M.; Tierney, J.T. Bias Due to Nonresponse in a Mail Survey of Rhode Island Physicians' Smoking Habits-1968. N. Engl. J. Med. 1970, 282, 908. [CrossRef] [PubMed]

52. Burgess, A.M.; Casey, D.B.; Tierney, J.T. Cigarette Smoking by Rhode Island Physicians, 1963-1973: Comparison with Lawyers and Other Adult Males. Am. J. Public Health 1978, 68, 63-65. [CrossRef]

53. Ceraso, M.; McElroy, J.A.; Kuang, X.; Vila, P.M.; Jorenby, D.E.; Fiore, M.C.; Du, X.; Qian, N.; Lu, L.; Ren, H. Smoking, Barriers to Quitting, and Smoking-Related Knowledge, Attitudes, and Patient Practices among Male Physicians in China. Prev. Chronic. Dis. 2008, 6, A06.

54. Chaudhry, M.; Chaudhry, I.; Rahman, M. Prevalence of Smoking among Health Care Providers in Tertiary Care Hospitals. RMJ 2007, 34, 40-42.

55. Coe, R.M.; Brehm, H.P. Smoking Habits of Physicians and Preventive Care Practices. HSMHA Health Rep. 1971, 86, $217-221$. [CrossRef] [PubMed]

56. Cofta, S.; Staszewski, R. Hospital Staff and Smoking Habits: Do We Need Modification of Smoking Behavior in Polish Hospitals? J. Physiol. Pharmacol. Off. J. Pol. Physiol. Soc. 2008, 59 (Suppl. S6), 191-199.

57. Das, P.; Basu, M.; Chowdhury, K.; Mallik, S.; Dhar, G.C.; Biswas, A. Observational Assessment and Correlates to Blood Pressure of Future Physicians of Bengal. Niger. J. Clin. Pract. 2013, 16, 433-438. [CrossRef] [PubMed] 
58. De Col, P.; Baron, C.; Guillaumin, C.; Bouquet, E.; Fanello, S. Influence of smoking among family physicians on their practice of giving minimal smoking cessation advice in 2008. A survey of 332 general practitioners in Maine-et-Loire. Rev. Mal. Respir. 2010, 27, 431-440. [CrossRef] [PubMed]

59. Dekker, H.M.; Looman, C.W.; Adriaanse, H.P.; van der Maas, P.J. Prevalence of Smoking in Physicians and Medical Students, and the Generation Effect in The Netherlands. Soc. Sci. Med. 1993, 36, 817-822. [CrossRef]

60. de Oliveira, G.S.; Chang, R.; Fitzgerald, P.C.; Almeida, M.D.; Castro-Alves, L.S.; Ahmad, S.; McCarthy, R.J. The Prevalence of Burnout and Depression and Their Association with Adherence to Safety and Practice Standards: A Survey of United States Anesthesiology Trainees. Anesth. Analg. 2013, 117, 182-193. [CrossRef] [PubMed]

61. Desalu, O.O.; Adekoya, A.O.; Elegbede, A.O.; Dosunmu, A.; Kolawole, T.F.; Nwogu, K.C. Knowledge of and Practices Related to Smoking Cessation among Physicians in Nigeria. J. Bras. Pneumol. 2009, 35, 1198-1203. [CrossRef]

62. Djalalinia, S.; Tehrani, F.R.; Malekafzali, H.; Dovvom, M.R.; Neot, R.; Peykari, N. Training of General Practitioners about Smoking Cessation Counseling. J. Pak. Med. Assoc. 2011, 61, 4.

63. Doll, R.; Hill, A.B. The Mortality of Doctors in Relation to Their Smoking Habits. BMJ 1954, 1, 1451-1455. [CrossRef] [PubMed]

64. Doll, R.; Hill, A.B. Mortality in Relation to Smoking: Ten Years' Observations of British Doctors. Br. Med. J. 1964, 1, 1399-1410. [CrossRef]

65. Doll, R.; Peto, R.; Wheatley, K.; Gray, R.; Sutherland, I. Mortality in Relation to Smoking: 40 Years' Observations on Male British Doctors. BMJ 1994, 309, 901-911. [CrossRef]

66. Doll, R.; Peto, R.; Boreham, J.; Sutherland, I. Mortality in Relation to Smoking: 50 Years' Observations on Male British Doctors. BMJ 2004, 328, 1519. [CrossRef] [PubMed]

67. Easton, A.; Husten, C.; Malarcher, A.; Elon, L.; Caraballo, R.; Ahluwalia, I.; Frank, E. Smoking Cessation Counseling by Primary Care Women Physicians: Women Physicians' Health Study. Women Health 2001, 32, 77-91. [CrossRef]

68. Edwards, R.; Bowler, T.; Atkinson, J.; Wilson, N. Low and Declining Cigarette Smoking Rates among Doctors and Nurses: 2006 New Zealand Census Data. N. Z. Med. J. 2008, 121, 43-51. [PubMed]

69. Edwards, R.; Tu, D.; Stanley, J.; Martin, G.; Newcombe, R. Smoking Prevalence among Doctors and Nurses-2013 New Zealand Census Data. N. Z. Med. J. 2018, 131, 10.

70. Fadhil, I.; Al Musawi, M. Tobacco Training and Educating Primary Care Professionals in Bahrain. J. Bahrain. Med. Soc. 2007, 19, 23-27.

71. Fanello, S.; Ripault, B.; Le Levier, F.; Guérin, O.; Penneau, D. [Smoking by general practitioners in Maine-et-Loire]. Rev. Epidemiol. Sante Publique 1990, 38, 78-79.

72. Fathi, A.; Ahari, S.S.; Amani, F.; Nikneghad, M.R. Study Frequency of Hypertension and Obesity and Their Relationship with Lifestyle Factors (Nutritional Habits, Physical Activity, Cigarette Consumption) in Ardabil City Physicians, 2012-2013. Indian J. Community Med. Off. Publ. Indian Assoc. Prev. Soc. Med. 2016, 41, 268-272. [CrossRef]

73. Franceschi, S.; Serraino, D.; Talamini, R.; Candiani, E. Personal Habits and Attitudes towards Smoking in a Sample of Physicians from the North-East of Italy. Int. J. Epidemiol. 1986, 15, 584-585. [CrossRef]

74. Frank, E.; Brogan, D.J.; Mokdad, A.H.; Simoes, E.J.; Kahn, H.S.; Greenberg, R.S. Health-Related Behaviors of Women Physicians vs. Other Women in the United States. Arch. Intern. Med. 1998, 158, 342-348. [CrossRef] [PubMed]

75. Frank, E.; Segura, C. Health Practices of Canadian Physicians. Can. Fam. Physician Med. Fam. Can. 2009, 55, 810-811.e7.

76. Freour, T.; Dessolle, L.; Jean, M.; Barriere, P. Smoking among French Infertility Specialists: Habits, Opinions and Patients Management. Eur. J. Obstet. Gynecol. Reprod. Biol. 2011, 155, 44-48. [CrossRef]

77. Garfinkel, L. Cigarette Smoking among Physicians and Other Health Professionals, 1959-1972. CA Cancer J. Clin. 1976, 26, 373-375. [CrossRef] [PubMed]

78. Grossman, D.W.; Knox, J.J.; Nash, C.; Jiménez, J.G. Smoking: Attitudes of Costa Rican Physicians and Opportunities for Intervention. Bull. World Health Organ. 1999, 77, 315-322. [PubMed]

79. Gunes, G.; Karaoglu, L.; Genc, M.F.; Pehlivan, E.; Egri, M. University Hospital Physicians' Attitudes and Practices for Smoking Cessation Counseling in Malatya, Turkey. Patient Educ. Couns. 2005, 56, 147-153. [CrossRef] [PubMed]

80. Gupta, G.; Schleinitz, M.D.; Reinert, S.E.; McGarry, K.A. Resident Physician Preventive Health Behaviors and Perspectives on Primary Care. R. I. Med. J. 2013, 96, 43-47.

81. Hallett, R. Intervention against Smoking and Its Relationship to General Practitioners' Smoking Habits. J. R. Coll. Gen. Pract. 1983, 33, 565-567.

82. Hamadeh, R.R. Smoking Habits of Primary Health Care Physicians in Bahrain. J. R. Soc. Promot. Health 1999, 119, 36-39. [CrossRef]

83. Li, H.Z.; Sun, W.; Cheng, F.; Wang, X.; Liu, W.; Wang, A. Cigarette Smoking Status and Smoking Cessation Counseling of Chinese Physicians in Wuhan, Hubei Province. Asia. Pac. J. Public Health 2008, 20, 183-192. [CrossRef]

84. Hay, D.R.; Christmas, B.W. The Smoking Habits of Women Doctors and Doctors' Wives in New Zealand. Prev. Med. 1976, 5, 78-88. [CrossRef]

85. Hay, D.R. Cigarette Smoking by New Zealand Doctors and Nurses: Results from the 1996 Population Census. N. Z. Med. J. 1998, 111, 102-104. [PubMed]

86. Heloma, A.; Reijula, K.; Tikkanen, J.; Nykyri, E. The Attitudes of Occupational Health Personnel to Smoking at Work. Am. J. Ind. Med. 1998, 34, 73-78. [CrossRef] 
87. Hensrud, D.D.; Sprafka, J.M. The Smoking Habits of Minnesota Physicians. Am. J. Public Health 1993, 83, 415-417. [CrossRef] [PubMed]

88. Heponiemi, T.; Kouvonen, A.; Vänskä, J.; Halila, H.; Sinervo, T.; Kivimäki, M.; Elovainio, M. Effects of Active On-Call Hours on Physicians' Turnover Intentions and Well-Being. Scand. J. Work. Environ. Health 2008, 34, 356-363. [CrossRef]

89. Hidalgo, K.D.; Mielke, G.I.; Parra, D.C.; Lobelo, F.; Simões, E.J.; Gomes, G.O.; Florindo, A.A.; Bracco, M.; Moura, L.; Brownson, R.C.; et al. Health Promoting Practices and Personal Lifestyle Behaviors of Brazilian Health Professionals. BMC Public Health 2016, 16, 1114. [CrossRef]

90. Hodgetts, G.; Broers, T.; Godwin, M. Smoking Behaviour, Knowledge and Attitudes among Family Medicine Physicians and Nurses in Bosnia and Herzegovina. BMC Fam. Pract. 2004, 5, 12. [CrossRef]

91. Hoseainrezaee, H.; Khodabandeh, S.; Kheradmand, A.; Pilehvarzadeh, M. Frequency of Smoking and Specialized Awareness among Doctors and Nurses of Hospitals in Kerman, Iran. Addict. Health 2013, 5, 51-56.

92. Huang, C.; Guo, C.; Yu, S.; Feng, Y.; Song, J.; Eriksen, M.; Redmon, P.; Koplan, J. Smoking Behaviours and Cessation Services among Male Physicians in China: Evidence from a Structural Equation Model. Tob. Control 2013, 22 (Suppl. S2), ii27-ii33. [CrossRef]

93. Hughes, P.H.; Conard, S.E.; Baldwin, D.C.; Storr, C.L.; Sheehan, D.V. Resident Physician Substance Use in the United States. JAMA 1991, 265, 2069-2073. [CrossRef] [PubMed]

94. Hughes, P.H.; Brandenburg, N.; Baldwin, D.C.; Storr, C.L.; Williams, K.M.; Anthony, J.C.; Sheehan, D.V. Prevalence of Substance Use among US Physicians. JAMA 1992, 267, 2333-2339. [CrossRef] [PubMed]

95. Hughes, P.H.; Storr, C.L.; Brandenburg, N.A.; Baldwin, D.C.; Anthony, J.C.; Sheehan, D.V. Physician Substance Use by Medical Specialty. J. Addict. Dis. 1999, 18, 23-37. [CrossRef]

96. Hung, O.Y.; Keenan, N.L.; Fang, J. Physicians' Health Habits Are Associated with Lifestyle Counseling for Hypertensive Patients. Am. J. Hypertens. 2013, 26, 201-208. [CrossRef] [PubMed]

97. Içli, F.; Içli, T.; Günel, N.; Arikan, R. Cigarette Smoking among Young Physicians and Their Approach to the Smoking Problem of Their Patients. J. Cancer Educ. Off. J. Am. Assoc. Cancer Educ. 1992, 7, 237-240. [CrossRef]

98. Jiang, Y.; Ong, M.K.; Tong, E.K.; Yang, Y.; Nan, Y.; Gan, Q.; Hu, T.-W. Chinese Physicians and Their Smoking Knowledge, Attitudes, and Practices. Am. J. Prev. Med. 2007, 33, 15-22. [CrossRef]

99. Jiménez-Ruiz, C.A.; Riesco Miranda, J.A.; Ramos Pinedo, A.; de Higes Martinez, E.; Marquez, F.L.; Palomo Cobos, L.; Solano Reina, S.; de Granda Orive, J.I.; de Lucas Ramos, P. Prevalence of and Attitudes towards Smoking among Spanish Health Professionals. Respir. Int. Rev. Thorac. Dis. 2015, 90, 474-480. [CrossRef] [PubMed]

100. Jingi, A.M.; Noubiap, J.J.N. Cardiovascular Risk Factors Awareness and Prevalence among Primary Care Physicians: An Insight from the West Region Awareness Initiative Survey to Fight Cardiovascular Disease (WAIT-CVD) in Cameroon. BMC Res. Notes 2015, 8, 762. [CrossRef]

101. John, U.; Hanke, M. Tobacco-Smoking Prevalence among Physicians and Nurses in Countries with Different Tobacco-Control Activities. Eur. J. Cancer Prev. 2003, 12, 235-237. [CrossRef]

102. Joossens, L.; Demedts, M.; Prignot, J.; Bartsch, P.; Gyselen, A. Smoking Habits of Belgian Physicians: Effects of Consonancy Behaviour and of Age. Acta Clin. Belg. 1987, 42, 457-461. [CrossRef]

103. Josseran, L.; King, G.; Velter, A.; Dressen, C.; Grizeau, D. Smoking Behavior and Opinions of French General Practitioners. J. Natl. Med. Assoc. 2000, 92, 382-390. [PubMed]

104. Josseran, L.; King, G.; Guilbert, P.; Davis, J.; Brücker, G. Smoking by French General Practitioners: Behaviour, Attitudes and Practice. Eur. J. Public Health 2005, 15, 33-38. [CrossRef]

105. Julião, A.M.; Camargo, A.L.L.S.; Cítero, V.D.A.; Maranhão, M.F.; Maluf Neto, A.; Paes, A.T.; Glezer, M.; Cendoroglo Neto, M.; Schvartsman, C. Physicians' Attitude towards Tobacco Dependence in a Private Hospital in the City of São Paulo, Brazil. Einstein Sao Paulo Braz. 2013, 11, 158-162. [CrossRef]

106. Kaetsu, A.; Fukushima, T.; Moriyama, M.; Shigematsu, T. Smoking Behavior and Related Lifestyle Variables among Physicians in Fukuoka, Japan: A Cross Sectional Study. J. Epidemiol. 2002, 12, 199-207. [CrossRef] [PubMed]

107. Kaneita, Y.; Uchida, T.; Ohida, T. Epidemiological Study of Smoking among Japanese Physicians. Prev. Med. 2010, 51, 164-167. [CrossRef]

108. Kawahara, K.; Ohida, T.; Osaki, Y.; Mochizuki, Y.; Minowa, M.; Yamaguchi, N.; Kusaka, Y. Study of the Smoking Behavior of Medical Doctors in Fukui, Japan and Their Antismoking Measures. J. Epidemiol. 2000, 10, 157-162. [CrossRef] [PubMed]

109. Kawakami, M.; Nakamura, S.; Fumimoto, H.; Takizawa, J.; Baba, M. Relation between Smoking Status of Physicians and Their Enthusiasm to Offer Smoking Cessation Advice. Intern. Med. 1997, 36, 162-165. [CrossRef]

110. Kawane, H. The Prevalence of Smoking among Physicians in Japan. Am. J. Public Health 1993, 83, 1640. [CrossRef]

111. Kotz, D.; Wagena, E.J.; Wesseling, G. Smoking Cessation Practices of Dutch General Practitioners, Cardiologists, and Lung Physicians. Respir. Med. 2007, 101, 568-573. [CrossRef]

112. Lam, T.H.; Jiang, C.; Chan, Y.-F.; Chan, S.S.C. Smoking Cessation Intervention Practices in Chinese Physicians: Do Gender and Smoking Status Matter? Health Soc. Care Community 2011, 19, 126-137. [CrossRef]

113. La Vecchia, C.; Scarpino, V.; Malvezzi, I.; Baldi, G. A Survey of Smoking among Italian Doctors. J. Epidemiol. Community Health 2000, 54, 320. [CrossRef] 
114. Lefcoe, N.M.; Wonnacott, T.H. The Prevalence of Chronic Respiratory Disease in the Male Physicians of London, Ontario. Can. Med. Assoc. J. 1970, 102, 381-385.

115. Legnini, M.W.; Claus, E.B. Smoking among Yale Medical School Faculty. Yale J. Biol. Med. 1987, 60, 9-18.

116. Lindfors, P.M.; Meretoja, O.A.; Luukkonen, R.A.; Elovainio, M.J.; Leino, T.J. Suicidality among Finnish Anaesthesiologists. Acta Anaesthesiol. Scand. 2009, 53, 1027-1035. [CrossRef] [PubMed]

117. Lipp, M.; Tinklenberg, J.; Benson, S.; Melges, F.; Taintor, Z.; Peterson, M. Medical Student Use of Marijuana, Alcohol, and Cigarettes: A Study of Four Schools. Int. J. Addict. 1972, 7, 141-152. [CrossRef] [PubMed]

118. Lipp, M.R.; Benson, S.G. Physician Use of Marijuana, Alcohol, and Tobacco. Am. J. Psychiatry 1972, 129, 612-616. [CrossRef]

119. Magee, M.J.; Darchia, L.; Kipiani, M.; Chakhaia, T.; Kempker, R.R.; Tukvadze, N.; Berg, C.J.; Blumberg, H.M. Smoking Behavior and Beliefs about the Impact of Smoking on Anti-Tuberculosis Treatment among Health Care Workers. Int. J. Tuberc. Lung Dis. Off. J. Int. Union Tuberc. Lung Dis. 2017, 21, 1049-1055. [CrossRef] [PubMed]

120. Malik, A.K.; Chaudhry, A.; Karamat, A.; Arif, N.; Cheema, M.A.; Rauf, A. Cigarette Smoking and Health Care Professionals at Mayo Hospital, Lahore, Pakistan. JPMA J. Pak. Med. Assoc. 2010, 60, 509-512.

121. Marakoğlu, K.; Kutlu, R.; Sahsivar, S. The Frequency of Smoking, Quitting and Socio-Demographic Characteristics of Physicians of a Medical Faculty. West Indian Med. J. 2006, 55, 160-164. [CrossRef] [PubMed]

122. Márk, L.; Nagy, E.; Kondacs, A.; Deli, L. The Change of Attitude of Hungarian Physicians towards the Importance of Risk Factors of Coronary Heart Disease over the Period 1985-1996. Public Health 1998, 112, 197-201. [CrossRef]

123. Mathavan, A.; Chockalingam, A.; Chockalingam, S.; Bilchik, B.; Saini, V. Madurai Area Physicians Cardiovascular Health Evaluation Survey (MAPCHES)_An Alarming Status. Can. J. Cardiol. 2009, 25, 303-308. [CrossRef]

124. McAuliffe, W.E.; Rohman, M.; Wechsler, H. Alcohol, Substance Use, and Other Risk-Factors of Impairment in a Sample of Physicians-in-Training. Adv. Alcohol Subst. Abuse 1984, 4, 67-87. [CrossRef]

125. McGrady, F.P.; McGlade, K.J.; Cupples, M.E.; Tully, M.A.; Hart, N.; Steele, K. Questionnaire Survey of PHysical ActivITy in General Practitioners (PHIT GP Study). Ulster Med. J. 2007, 76, 91-97.

126. Merrill, R.M.; Madanat, H.; Layton, J.B.; Hanson, C.L.; Madsen, C.C. Smoking Prevalence, Attitudes, and Perceived Smoking Prevention and Control Responsibilities and Behaviors among Physicians in Jordan. Int. Q. Community Health Educ. 2006, 26, 397-413. [CrossRef]

127. Meshefedjian, G.A.; Gervais, A.; Tremblay, M.D.; Villeneuve, D.; O’loughlin, J. Physician Smoking Status May Influence Cessation Counseling Practices. Can. J. Public Health Rev. Can. Sante Publique 2010, 101, 290-293. [CrossRef]

128. Mikalauskas, A.; Širvinskas, E.; Marchertienè, I.; Macas, A.; Samalavičius, R.; Kinduris, Š.; Benetis, R. Burnout among Lithuanian Cardiac Surgeons and Cardiac Anesthesiologists. Med. Kaunas Lith. 2012, 48, 478-484. [CrossRef]

129. Misra, R.; Vadaparampil, S.T. Personal Cancer Prevention and Screening Practices among Asian Indian Physicians in the United States. Cancer Detect. Prev. 2004, 28, 269-276. [CrossRef] [PubMed]

130. Mohseni-Bandpei, M.A.; Ahmad-Shirvani, M.; Golbabaei, N.; Behtash, H.; Shahinfar, Z.; Fernández-de-las-Peñas, C. Prevalence and Risk Factors Associated with Low Back Pain in Iranian Surgeons. J. Manip. Physiol. Ther. 2011, 34, 362-370. [CrossRef] [PubMed]

131. Moreno San-Pedro, E.; San-Pedro, E.M.; Roales-Nieto, J.G.; Blanco-Coronado, J.L. Tobacco Use among Spanish Physicians and Medical Students. Tob. Control 2006, 15, 272. [CrossRef]

132. Mubeen, S.M.; Morrow, M.; Barraclough, S. Smoking among Future Doctors in a "No-Smoking" University Campus in Karachi, Pakistan: Issues of Tobacco Control. J. Pak. Med. Assoc. 2008, 58, 6.

133. Naji, N.; McLoughlin, H.; Connell, F.O.; Clancy, L. Smoking Profile of Non-Consultant Hospital Doctors. Ir. J. Med. Sci. 2006, 175, 29-31. [CrossRef] [PubMed]

134. Nakladalova, M.; Sovova, E.; Ivanova, K.; Kaletova, M.; Lukl, J.; Fialova, J. Risk Factors for Cardiovascular Diseases in Physicians. Biomed. Pap. 2005, 149, 293-295. [CrossRef]

135. Nardini, S.; Bertoletti, R.; Rastelli, V.; Donner, C.F. The Influence of Personal Tobacco Smoking on the Clinical Practice of Italian Chest Physicians. Eur. Respir. J. 1998, 12, 1450-1453. [CrossRef] [PubMed]

136. Nawaz, A.; Naqvi, S.A.A. Attitudes, Perceptions, Habits of Smoker, Non-Smoker General Practitioners and Why They Fail to Motivate Patients to Quit Smoking. Pak. J. Med. Sci. 2008, 24, 152-156.

137. Ndiaye, M.; Hane, A.A.; Ndir, M.; Ba, O.; Diop-Dia, D.; Kandji, M.; Ndiaye, S.; Toure, N.O.; Diatta, A.; Dia, Y.; et al. [Smoking habits among physicians in Dakar]. Rev. Pneumol. Clin. 2001, 57, 7-11.

138. Nelson, D.E.; Giovino, G.A.; Emont, S.L.; Brackbill, R.; Cameron, L.L.; Peddicord, J.; Mowery, P.D. Trends in Cigarette Smoking among US Physicians and Nurses. JAMA 1994, 271, 1273-1275. [CrossRef]

139. Nutbeam, D.; Catford, J. Modifiable Risks for Cardiovascular Disease among General Practitioners in Wales. Public Health 1990, 104, 353-361. [CrossRef]

140. Obeidat, N.A.; Habashneh, M.A.; Shihab, R.A.; Hawari, F.I. Are Jordanian Primary Healthcare Practitioners Fulfilling Their Potential in Cancer Prevention and Community Health? Findings from a Cross-Sectional Survey. BMJ Open 2017, 7, e015269. [CrossRef]

141. O'Cathail, M.; O'Callaghan, M. A Profile of Hospital Consultants: The Health Practices of a Cohort of Medical Professionals. Ir. Med. J. 2013, 106, 134-136. 
142. Ohida, T.; Sakurai, H.; Mochizuki, Y.; Kamal, A.M.; Takemura, S.; Minowa, M.; Kawahara, K. Smoking Prevalence and Attitudes toward Smoking among Japanese Physicians. JAMA 2001, 285, 2643-2648. [CrossRef]

143. O' Keeffe, A.; Hayes, B.; Prihodova, L. “Do as We Say, Not as We Do?" The Lifestyle Behaviours of Hospital Doctors Working in Ireland: A National Cross-Sectional Study. BMC Public Health 2019, 19, 179. [CrossRef]

144. Pärna, K.; Rahu, K.; Barengo, N.C.; Rahu, M.; Sandström, P.H.; Jormanainen, V.J.; Myllykangas, M.T. Comparison of Knowledge, Attitudes and Behaviour Regarding Smoking among Estonian and Finnish Physicians. Soz. Praventivmed. 2005, 50, 378-388. [CrossRef] [PubMed]

145. Pärna, K.; Rahu, K.; Rahu, M. Smoking Habits and Attitudes towards Smoking among Estonian Physicians. Public Health 2005, 119, 390-399. [CrossRef]

146. Pärna, K.; Põld, M.; Ringmets, I. Trends in Smoking Behaviour among Estonian Physicians in 1982-2014. BMC Public Health 2017, 18, 55. [CrossRef] [PubMed]

147. Perrin, P.C.; Merrill, R.M.; Lindsay, G.B. Patterns of Smoking Behavior among Physicians in Yerevan, Armenia. BMC Public Health 2006, 6, 139. [CrossRef]

148. Peykari, N.F.; Tehrani, F.R.; Afzali, H.M.; Dovvon, M.R.; Djalalinia, S.S. Smoking Habits among Iranian General Practitioners. J. Egypt. Public Health Assoc. 2010, 85, 97-112. [PubMed]

149. Phillips, A.J.; Taylor, R.M. Smoking Habits of Physicians in Canada. Can. Med. Assoc. J. 1968, 99, $955-957$.

150. Pipe, A.; Sorensen, M.; Reid, R. Physician Smoking Status, Attitudes toward Smoking, and Cessation Advice to Patients: An International Survey. Patient Educ. Couns. 2009, 74, 118-123. [CrossRef]

151. Piryani, R.M.; Rizvi, N. Smoking Habits amongst House Physicians Working at Jinnah Postgraduate Medical Center, Karachi, Pakistan. Trop. Doct. 2004, 34, 44-45. [CrossRef]

152. Pizzo, A.M.; Chellini, E.; Grazzini, G.; Cardone, A.; Badellino, F. Italian General Practitioners and Smoking Cessation Strategies. Tumori 2003, 89, 250-254. [CrossRef]

153. Poantă, L.I.; Zdrenghea, D.; Albu, A. Psychometric Evaluation of Romanian Version of Job Content Questionnaire in Physicians. Rom. J. Intern. Med. Rev. Roum. Med. Interne 2006, 44, 183-199.

154. Põld, M.; Pärna, K. Smoking Prevalence and Attitudes towards Smoking among Estonian Physicians: Results from Cross-Sectional Studies in 2002 and 2014. BMJ Open 2017, 7, e017197. [CrossRef]

155. Ramachandran, A.; Snehalatha, C.; Yamuna, A.; Murugesan, N. High Prevalence of Cardiometabolic Risk Factors among Young Physicians in India. J. Assoc. Physicians India 2008, 56, 17-20.

156. Ranchal Sánchez, A.; Pérula de Torres, L.Á.; Santos Luna, F.; Ruiz-Moral, R. Prevalence of Tobacco Consumption among Young Physicians at a Regional University Hospital in Southern Spain: A Cross-Sectional Study. BMJ Open 2018, 8, e018728. [CrossRef]

157. Rankin, D.W.; Gray, N.J.; Hill, D.J.; Evans, D.R. Attitudes and Smoking Habits of Australian Doctors. Med. J. Aust. 1975, 2, 822-824. [CrossRef] [PubMed]

158. Ravara, S.B.; Castelo-Branco, M.; Aguiar, P.; Calheiros, J.M. Smoking Behaviour Trends among Portuguese Physicians: Are They Role Models? A Conference-Based Survey. Public Health 2014, 128, 105-109. [CrossRef]

159. Reile, R.; Pärna, K. Do Physicians Address Their Patients' Smoking Behavior? Results from a Nationwide Survey among Physicians in Estonia. Public Health 2018, 161, 1-4. [CrossRef]

160. Saeed, A.A. Attitudes and Behaviour of Physicians towards Smoking in Riyadh City, Saudi Arabia. Trop. Geogr. Med. 1991, 43, 76-79.

161. Saeys, F.; Cammu, H. GPs' Attitudes on a Healthy Lifestyle: A Survey of GPs in Flanders. Br. J. Gen. Pract. 2014, 64, e664-e669. [CrossRef] [PubMed]

162. Salgado, M.V.; Mejia, R.; Kaplan, C.P.; Perez-Stable, E.J. Smoking Behavior and Use of Tobacco Industry Sponsored Websites Among Medical Students and Young Physicians in Argentina. J. Med. Internet Res. 2014, 16, e35. [CrossRef]

163. Samuels, N. Smoking among Hospital Doctors in Israel and Their Attitudes Regarding Anti-Smoking Legislation. Public Health 1997, 111, 285-288. [CrossRef]

164. Scott, H.D.; Tierney, J.T.; Buechner, J.S.; Waters, W.J. Smoking Rates among Rhode Island Physicians: Achieving a Smoke-Free Society. Am. J. Prev. Med. 1992, 8, 86-90. [CrossRef]

165. Sebo, P.; Bouvier Gallacchi, M.; Goehring, C.; Künzi, B.; Bovier, P.A. Use of Tobacco and Alcohol by Swiss Primary Care Physicians: A Cross-Sectional Survey. BMC Public Health 2007, 7, 5. [CrossRef]

166. Sharma, T.D. Smoking Declines in a Group of Indian Doctors. World Health Forum 1988, 9, $219-220$.

167. Shkedy, Y.; Feinmesser, R.M.; Mizrachi, A. Smoking Habits among Israeli Hospital Doctors: A Survey and Historical Review. Isr. Med. Assoc. J. 2013, 15, 339-341.

168. Shishani, K.; Nawafleh, H.; Sivarajan Froelicher, E. Jordanian Nurses' and Physicians' Learning Needs for Promoting Smoking Cessation. Prog. Cardiovasc. Nurs. 2008, 23, 79-83. [CrossRef] [PubMed]

169. Shishani, K.; Nawafleh, H.; Jarrah, S.; Froelicher, E.S. Smoking Patterns among Jordanian Health Professionals: A Study about the Impediments to Tobacco Control in Jordan. Eur. J. Cardiovasc. Nurs. J. 2011, 10, 221-227. [CrossRef]

170. Siddiqui, S.; Ogbeide, D.O. Profile of Smoking amongst Health Staff in a Primary Care Unit at a General Hospital in Riyadh, Saudi Arabia. Saudi Med. J. 2001, 22, 1101-1104.

171. Singh, G.; Singh, R.; Jindal, K.C. Drug Use among Physicians and Medical Students. Indian J. Med. Res. 1981, 73, 594-602. 
172. Smith, D.R.; Wei, N.; Zhang, Y.-J.; Wang, R.-S. Tobacco Smoking Habits among a Cross-Section of Rural Physicians in China. Aust. J. Rural Health 2006, 14, 66-71. [CrossRef] [PubMed]

173. Smith, D.R.; Leggat, P.A. Tobacco Smoking Was Dramatically Reduced among New Zealand Health Care Workers between 1963 and 1996, but What Happened after That? N. Z. Med. J. 2007, 120, U2758. [PubMed]

174. Sotiropoulos, A.; Gikas, A.; Spanou, E.; Dimitrelos, D.; Karakostas, F.; Skliros, E.; Apostolou, O.; Politakis, P.; Pappas, S. Smoking Habits and Associated Factors among Greek Physicians. Public Health 2007, 121, 333-340. [CrossRef] [PubMed]

175. Squier, C.; Hesli, V.; Lowe, J.; Ponamorenko, V.; Medvedovskaya, N. Tobacco Use, Cessation Advice to Patients and Attitudes to Tobacco Control among Physicians in Ukraine. Eur. J. Cancer Prev. 2006, 15, 458-463. [CrossRef] [PubMed]

176. Stuyt, E.B.; Gundersen, D.C.; Shore, J.H.; Brooks, E.; Gendel, M.H. Tobacco Use by Physicians in a Physician Health Program, Implications for Treatment and Monitoring. Am. J. Addict. 2009, 18, 103-108. [CrossRef] [PubMed]

177. Sundquist, J.; Johansson, S.E. Impaired Health Status, and Mental Health, Lower Vitality and Social Functioning in Women General Practitioners in Sweden. A Cross-Sectional Survey. Scand. J. Prim. Health Care 1999, 17, 81-86. [CrossRef]

178. Tapia-Conyer, R.; Cravioto, P.; de la Rosa, B.; Galván, F.; García-de la Torre, G.; Kuri, P. Cigarette Smoking; Knowledge and Attitudes among Mexican Physicians. Salud Publica Mex. 1997, 39, 507-512. [CrossRef] [PubMed]

179. Tee, G.H. Changing Habits and Attitudes Towards Smoking among Future Physicians. Med. J. Malays. $2007,62,5$.

180. Tessier, J.F.; Thomas, D.; Nejjari, C.; Belougne, D.; Freour, P. Attitudes of French cardiologists towards smoking. Arch. Mal. Coeur Vaiss. 1996, 89, 341-347. [CrossRef]

181. Thomas, I.; Gupta, S.; Sempos, C.; Cooper, R. Serum Lipids of Indian Physicians Living in the U.S. Compared to U.S.-Born Physicians. Atherosclerosis 1986, 61, 99-106. [CrossRef]

182. Tomson, T.; Boupha, K.; Gilljam, H.; Helgason, Á.R. Knowledge, Attitudes and Smoking Behavior among Lao Doctors. Southeast Asian J. Trop. Med. Public Health 2003, 34, 213-219.

183. Tong, E.K.; Strouse, R.; Hall, J.; Kovac, M.; Schroeder, S.A. National Survey of U.S. Health Professionals' Smoking Prevalence, Cessation Practices, and Beliefs. Nicotine Tob. Res. 2010, 12, 724-733. [CrossRef] [PubMed]

184. Tosun, O.; Dabak, R.; Sargin, M.; Dolapcioglu, C.; Ahishali, E. Frequency of Irritable Bowel Syndrome Among Healthcare Personnel. Gastroenterol. Nurs. 2016, 39, 227-231. [CrossRef]

185. Trédaniel, J.; Karsenty, S.; Chastang, C.; Slama, K.; Hirsch, A. Smoking habits of French general practitioners. Results of a representative sample of 1012 physicians. Rev. Mal. Respir. 1993, 10, 35-38. [PubMed]

186. Ulbricht, S.; Baumeister, S.; Meyer, C.; Schmidt, C.; Schumann, A.; Rumpf, H.; John, U. Does the Smoking Status of General Practitioners Affect the Efficacy of Smoking Cessation Counselling? Patient Educ. Couns. 2009, 74, 23-28. [CrossRef] [PubMed]

187. Underner, M.; Laforgue, A.-V.; Chabaud, F.; Meurice, J.-C. Influence of doctors' smoking habits on minimal advice for smoking cessation. A survey of 369 general practitioners in the department of Vienne, France. Presse Med. 2004, 33, 927-929. [CrossRef]

188. Underner, M.; Ingrand, P.; Allouch, A.; Laforgue, A.V.; Migeot, V.; Defossez, G.; Meurice, J.C. Influence of smoking among family physicians on their practice of giving minimal smoking cessation advice. Rev. Mal. Respir. 2006, 23, 426-429. [CrossRef]

189. Uysal, M.A.; Dilmen, N.; Karasulu, L.; Demir, T. Smoking Habits among Physicians in Istanbul and Their Attitudes Regarding Anti-Smoking Legislation. Tuberk. Ve Toraks 2007, 55, 350-355.

190. Vanderhoek, A.J.; Hammal, F.; Chappell, A.; Wild, T.C.; Raupach, T.; Finegan, B.A. Future Physicians and Tobacco: An Online Survey of the Habits, Beliefs and Knowledge Base of Medical Students at a Canadian University. Tob. Induc. Dis. 2013, 11, 9. [CrossRef]

191. Vanphanom, S.; Morrow, M.; Phengsavanh, A.; Hansana, V.; Phommachanh, S.; Tomson, T. Smoking among Lao Medical Doctors: Challenges and Opportunities for Tobacco Control. Tob. Control 2011, 20, 144-150. [CrossRef]

192. Viegas, C.A.D.A.; de Andrade, A.P.A.; Silvestre, R.D.S. Characteristics of Smoking among Physicians in the Federal District of Brazil. J. Bras. Pneumol. 2007, 33, 76-80. [CrossRef]

193. Voigt, K.; Twork, S.; Mittag, D.; Göbel, A.; Voigt, R.; Klewer, J.; Kugler, J.; Bornstein, S.R.; Bergmann, A. Consumption of Alcohol, Cigarettes and Illegal Substances among Physicians and Medical Students in Brandenburg and Saxony (Germany). BMC Health Serv. Res. 2009, 9, 219. [CrossRef] [PubMed]

194. Waalkens, H.J.; Cohen Schotanus, J.; Adriaanse, H.; Knol, K. Smoking Habits in Medical Students and Physicians in Groningen, The Netherlands. Eur. Respir. J. 1992, 5, 49-52. [PubMed]

195. Wyshak, G.; Lamb, G.A.; Lawrence, R.S.; Curran, W.J. A Profile of the Health-Promoting Behaviors of Physicians and Lawyers. N. Engl. J. Med. 1980, 303, 104-107. [CrossRef] [PubMed]

196. Yaacob, I.; Abdullah, Z.A. Smoking Habits and Attitudes among Doctors in a Malaysian Hospital. Southeast Asian J. Trop. Med. Public Health 1993, 24, 28-31.

197. Yan, J.; Xiao, S.; Ouyang, D.; Jiang, D.; He, C.; Yi, S. Smoking Behavior, Knowledge, Attitudes and Practice among Health Care Providers in Changsha City, China. Nicotine Tob. Res. 2008, 10, 737-744. [CrossRef]

198. Young, J.M.; Ward, J.E. Declining Rates of Smoking among Medical Practitioners. Med. J. Aust. 1997, 167, 232. [CrossRef]

199. Zabadi, H.A.; Musmar, S.; Hassouna, A.; Shtaiwi, D. Cigarettes and Water Pipe Smoking Prevalence, Knowledge, and Attitudes Among the Palestinian Physicians in the West Bank. Tob. Use Insights 2018, 11, 1179173X18813369. [CrossRef] [PubMed]

200. Zhang, H. Cigarette Smoking among Chinese Medical Staff. Lancet Lond. Engl. 2015, 385, 1621. [CrossRef]

201. Zhou, J.; Abdullah, A.S.; Pun, V.C.; Huang, D.; Lu, S.; Luo, S. Smoking Status and Cessation Counseling Practices among Physicians, Guangxi, China, 2007. Prev. Chronic. Dis. 2010, 7, A15. 
202. Zinonos, S.; Zachariadou, T.; Zannetos, S.; Panayiotou, A.G.; Georgiou, A. Smoking Prevalence and Associated Risk Factors among Healthcare Professionals in Nicosia General Hospital, Cyprus: A Cross-Sectional Study. Tob. Induc. Dis. 2016, 14, 1-8. [CrossRef]

203. Zylbersztejn, H.; Masson, W.; Lobo, M.L.; Manente, D.; García Aurelio, M.; Angel, A.; Mulassi, A.; Giorgi, M.; Rostán, M.G. The TAMARA II Trial. Smoking Among Physicians in Argentina. Rev. Argent. Cardiol. 2015, 83, 222-231. [CrossRef]

204. Amara, B.; El Ghazi, K.; Rahimi, H.; Elbiaze, M.; Nejjari, C.; Chakib Benjelloun, M. Attitudes et connaissances des pneumophtisiologues marocains vis-à-vis du tabagisme chez leurs patients tuberculeux. Rev. Mal. Respir. 2008, 25, 569-575. [CrossRef]

205. Nollen, N.L.; Adewale, S.; Okuyemi, K.S.; Ahluwalia, J.S.; Parakoyi, A. Workplace Tobacco Policies and Smoking Cessation Practices of Physicians. J. Natl. Med. Assoc. 2004, 96, 838-842.

206. Shi, Y.; Yu, C.; Luo, A.; Huang, Y.; Warner, D.O. Perioperative Tobacco Interventions by Chinese Anesthesiologists: Practices and Attitudes. Anesthesiology 2010, 112, 338-346. [CrossRef]

207. Mohan, S.; Pradeepkumar, A.S.; Thresia, C.U.; Thankappan, K.R.; Poston, W.S.C.; Haddock, C.K.; Pinkston, M.M.; Muramoto, M.L.; Nichter, M.; Nichter, M.; et al. Tobacco Use among Medical Professionals in Kerala, India: The Need for Enhanced Tobacco Cessation and Control Efforts. Addict. Behav. 2006, 31, 2313-2318. [CrossRef] [PubMed]

208. Varona, P. Use of Medical Counseling for the Prevention and Control of Smoking in the Municipality of Old Havana. J. Urban Health Bull. N. Y. Acad. Med. 2005, 82, 71-75. [CrossRef] [PubMed]

209. Easton, A.; Husten, C.; Elon, L.; Pederson, L.; Frank, E. Non-Primary Care Physicians and Smoking Cessation Counseling: Women Physicians' Health Study. Women Health 2001, 34, 15-29. [CrossRef] [PubMed]

210. Jacot Sadowski, I.; Ruffieux, C.; Cornuz, J. Self-Reported Smoking Cessation Activities among Swiss Primary Care Physicians. BMC Fam. Pract. 2009, 10, 22. [CrossRef] [PubMed]

211. Oztürk, O.; Yılmazer, I.; Akkaya, A. The Attitudes of Surgeons Concerning Preoperative Smoking Cessation: A Questionnaire Study. Hippokratia 2012, 16, 124-129.

212. Schnoll, R.A.; Engstrom, P.F.; Subramanian, S.; Demidov, L.; Wielt, D.B. Smoking Cessation Counseling by Russian Oncologists: Opportunities for Intervention in the Russian Federation. Int. J. Behav. Med. 2006, 13, 8-15. [CrossRef]

213. Steinberg, M.B.; Nanavati, K.; Delnevo, C.D.; Abatemarco, D.J. Predictors of Self-Reported Discussion of Cessation Medications by Physicians in New Jersey. Addict. Behav. 2007, 32, 3045-3053. [CrossRef] [PubMed]

214. Thankappan, K.R.; Pradeepkumar, A.S.; Nichter, M. Doctors' Behaviour \& Skills for Tobacco Cessation in Kerala. Indian J. Med. Res. 2009, 129, 249-255.

215. An, L. Treatment of Tobacco Use as a Chronic Medical Condition: Primary Care Physicians' Self-Reported Practice Patterns. Prev. Med. 2004, 38, 574-585. [CrossRef]

216. Power, B.; Neilson, S.; Perry, I.J. Perception of the Risks of Smoking in the General Population and among General Practitioners in Ireland. Ir. J. Med. Sci. 2004, 173, 141-144. [CrossRef]

217. Willaing, I.; Jørgensen, T.; Iversen, L. How Does Individual Smoking Behaviour among Hospital Staff Influence Their Knowledge of the Health Consequences of Smoking? Scand. J. Public Health 2003, 31, 149-155. [CrossRef] [PubMed]

218. McEwen, A.; West, R. Smoking Cessation Activities by General Practitioners and Practice Nurses. Tob. Control 2001, 10, 27-32. [CrossRef]

219. Hepburn, M.J.; Johnson, J.M.; Ward, J.A.; Longfield, J.N. A Survey of Smoking Cessation Knowledge, Training, and Practice among U.S. Army General Medical Officers. Am. J. Prev. Med. 2000, 18, 300-304. [CrossRef]

220. Zanetti, F. Smoking Habits, Exposure to Passive Smoking and Attitudes to a Non-Smoking Policy among Hospital Staff. Public Health 1998, 112, 57-62. [CrossRef]

221. Roche, A.M.; Parle, M.D.; Saunders, J.B. Managing Alcohol and Drug Problems in General Practice: A Survey of Trainees' Knowledge, Attitudes and Educational Requirements. Aust. N. Z. J. Public Health 1996, 20, 401-408. [CrossRef] [PubMed]

222. Roche, A.M.; Parle, M.D.; Stubbs, J.M.; Hall, W.; Saunders, J.B. Management and Treatment Efficacy of Drug and Alcohol Problems: What Do Doctors Believe? Addict. Abingdon Engl. 1995, 90, 1357-1366. [CrossRef]

223. Hill, H.A.; Braithwaite, R.L. Attitudes, Beliefs, and Practices Regarding Smoking and Smoking Cessation among African-American Physicians and Dentists. J. Natl. Med. Assoc. 1997, 89, 745-751. [PubMed]

224. Polyzos, A.; Gennatas, C.; Veslemes, M.; Daskalopoulou, E.; Stamatiadis, D.; Katsilambros, N. The Smoking-Cessation Promotion Practices of Physician Smokers in Greece. J. Cancer Educ. 1995, 10, 78-81. [CrossRef]

225. Hussain, S.F.; Tjeder-Burton, S.; Campbell, I.A.; Davies, P.D. Attitudes to Smoking and Smoking Habits among Hospital Staff. Thorax 1993, 48, 174-175. [CrossRef] [PubMed]

226. Brink, S.G.; Gottlieb, N.H.; McLeroy, K.R.; Wisotzky, M.; Burdine, J.N. A Community View of Smoking Cessation Counseling in the Practices of Physicians and Dentists. Public Health Rep. 1994, 109, 135-142. [PubMed]

227. Fowler, G.; Fuller, A.; Mant, D.; Jones, L. The "Help Your Patient Stop" Initiative: Evaluation of Smoking Prevalence and Dissemination of WHO/UICC Guidelines in UK General Practice. Lancet 1989, 333, 1253-1255. [CrossRef]

228. Davies, P.D.; Rajan, K. Attitudes to Smoking and Smoking Habit among the Staff of a Hospital. Thorax 1989, 44, 378-381. [CrossRef]

229. Linn, L.S.; Yager, J.; Cope, D.; Leake, B. Health Habits and Coping Behaviors among Practicing Physicians. West. J. Med. 1986, 144, 484-489. [PubMed]

230. Sachs, D.P. Smoking Habits of Pulmonary Physicians. N. Engl. J. Med. 1983, 309, 799. [CrossRef] 
231. Seiler, E.R. Smoking Habits of Doctors and Their Spouses in South East Scotland. J. R. Coll. Gen. Pract. 1983, $33,598$.

232. Senior, S.L. Study of Smoking Habits in Hospital and Attitudes of Medical Staff towards Smoking. Can. Med. Assoc. J. 1982, 126, 131-133.

233. Dodds, A.M.; Rankin, D.W.; Hill, D.J.; Gray, N.J. Attitudes and Smoking Habits of Doctors in Victoria. Community Health Stud. 1979, 3, 28-31. [CrossRef]

234. Abdullah, A.S.M.; Rahman, M.A.S.M.; Suen, C.W.; Wing, L.S.; Ling, L.W.; Mei, L.Y.; Tat, L.C.; Tai, M.N.; Wing, T.N.; Yuen, W.T.; et al. Investigation of Hong Kong Doctors' Current Knowledge, Beliefs, Attitudes, Confidence and Practices: Implications for the Treatment of Tobacco Dependency. J. Chin. Med. Assoc. 2006, 69, 461-471. [CrossRef]

235. Shin, S.S.; Xiao, D.; Cao, M.; Wang, C.; Li, Q.; Chai, W.-X.; Lindsay, R.P.; Usita, P.; Novotny, T.E. Patient and Doctor Perspectives on Incorporating Smoking Cessation into Tuberculosis Care in Beijing, China. Int. J. Tuberc. Lung Dis. 2012, 16, 126-131. [CrossRef]

236. Zhang, C.; Xiao, D.; West, R.; Michie, S.; Troughton, R.; Hajek, P.; Wang, C. Evaluation of 3-Day Smoking Cessation Training Course for Doctors from 38 Cities in China. Chin. Med. J. 2012, 125, 1338-1340. [PubMed]

237. Miwa, K.; Fujita, M.; Miyagi, Y.; Inoue, H.; Sasayama, S. Is Smoking Behaviour in Patients with Coronary Heart Disease Influenced by Whether Their Attending Physician Smokes? Tob. Control 1995, 4, 236-238. [CrossRef]

238. Wada, K.; Sakata, Y.; Theriault, G.; Narai, R.; Yoshino, Y.; Tanaka, K.; Aizawa, Y. Associations of Excessive Sleepiness on Duty with Sleeping Hours and Number of Days of Overnight Work among Medical Residents in Japan. J. Occup. Health 2007, 49, 523-527. [CrossRef] [PubMed]

239. Wada, K. Lifestyle Habits among Physicians Working AtHospitals in Japan. JMAJ 2011, 54, 318-324.

240. Kai, T.; Maki, T.; Takahashi, S.; Warner, D. Perioperative Tobacco Use Interventions in Japan: A Survey of Thoracic Surgeons and Anaesthesiologists. Br. J. Anaesth. 2008, 100, 404-410. [CrossRef] [PubMed]

241. Ng, N.; Prabandari, Y.S.; Padmawati, R.S.; Okah, F.; Haddock, C.K.; Nichter, M.; Nichter, M.; Muramoto, M.; Poston, W.S.C.; Pyle, S.A.; et al. Physician Assessment of Patient Smoking in Indonesia: A Public Health Priority. Tob. Control 2007, 16, 190-196. [CrossRef]

242. Mejia, R.; Martinez, V.G.; Gregorich, S.E.; Pérez-Stable, E.J. Physician Counseling of Pregnant Women about Active and Secondhand Smoking in Argentina. Acta Obstet. Gynecol. Scand. 2010, 89, 490-495. [CrossRef]

243. Al Shahrani, A.S.; Almudaiheem, N.R.; Bakhsh, E.M.; Sarhan, N.T.; Aldossari, F.S.; bin Huzeim, B.A. Understanding Smoking Behavior among Physicians in Riyadh, Saudi Arabia: A Cross-Sectional Study. Tob. Use Insights 2021, 14, 1179173X211006652. [CrossRef]

244. Carlos, S.; Rico-Campà, A.; de la Fuente-Arrillaga, C.; Echavarri, M.; Fernandez-Montero, A.; Gea, A.; Salazar, C.; MartínezGonzález, M.A. Do Healthy Doctors Deliver Better Messages of Health Promotion to Their Patients?: Data from the SUN Cohort Study. Eur. J. Public Health 2020, 30, 466-472. [CrossRef]

245. Pillay, R.; Rathish, B.; Philips, G.M.; Kumar, R.A.; Francis, A. Cardiovascular and Stroke Disease Risk among Doctors: A Cross-Sectional Study. Trop. Doct. 2020, 50, 232-234. [CrossRef]

246. Põld, M.; Pärna, K. Nicotine Dependence and Factors Related to Smoking Cessation among Physicians in Estonia. Int. J. Environ. Res. Public. Health 2020, 17, 3217. [CrossRef] [PubMed]

247. Wang, Q.; Zhang, X.; Wang, Z.; Feng, S.; Li, Y.; Zhang, C.; Wang, C. Doctors' Smoking Control Knowledge, Attitudes and Practices: A Cross-Sectional Study Conducted in Shandong Province, China. BMC Public Health 2021, 21, 73. [CrossRef]

248. Wilson, H.H.K.; Norris, R.; Tapley, A.; Magin, P.; Klein, L. Role Legitimacy, Comfort and Confidence Providing Tobacco, Alcohol and Other Drug Care: A Cross-Sectional Study of Australian Early-Career General Practitioners. Educ. Prim. Care 2021, 32, 19-26. [CrossRef] [PubMed]

249. Wilf Miron, R.; Malatskey, L.; Rosen, L.J. Health-Related Behaviours and Perceptions among Physicians: Results from a CrossSectional Study in Israel. BMJ Open 2019, 9, e031353. [CrossRef] [PubMed]

250. Movsisyan, N.K.; Petrosyan, V.; Abelyan, G.; Sochor, O.; Baghdasaryan, S.; Etter, J.-F. Learning to Assist Smokers through Encounters with Standardized Patients: An Innovative Training for Physicians in an Eastern European Country. PLoS ONE 2019, 14, e0222813. [CrossRef] [PubMed]

251. Kaetsu, A.; Fukushima, T.; Moriyama, M.; Shigematsu, T. Change of the Smoking Behavior and Related Lifestyle Variables among Physicians in Fukuoka, Japan: A Longitudinal Study. J. Epidemiol. 2002, 12, 208-216. [CrossRef]

252. Cao, Y.; Kenfield, S.; Song, Y.; Rosner, B.; Qiu, W.; Sesso, H.D.; Gaziano, J.M.; Ma, J. Cigarette Smoking Cessation and Total and Cause-Specific Mortality: A 22-Year Follow-up Study among US Male Physicians. Arch. Intern. Med. 2011, 171, 1956-1959. [CrossRef]

253. Innos, K.; Rahu, K.; Baburin, A.; Rahu, M. Cancer Incidence and Cause-Specific Mortality in Male and Female Physicians: A Cohort Study in Estonia. Scand. J. Public Health 2002, 30, 133-140. [CrossRef]

254. Kono, S.; Ikeda, M.; Tokudome, S.; Nishizumi, M.; Kuratsune, M. Smoking and Mortalities from Cancer, Coronary Heart Disease and Stroke in Male Japanese Physicians. J. Cancer Res. Clin. Oncol. 1985, 110, 161-164. [CrossRef] [PubMed]

255. Manson, J.E.; Ajani, U.A.; Liu, S.; Nathan, D.M.; Hennekens, C.H. A Prospective Study of Cigarette Smoking and the Incidence of Diabetes Mellitus among US Male Physicians. Am. J. Med. 2000, 109, 538-542. [CrossRef]

256. Rurik, I.; Kalabay, L. Morbidity, Demography, Life Style, and Self-Perceived Health of Hungarian Medical Doctors 25 Years after Graduation. Med. Sci. Monit. 2008, 14, SR1-SR8. 
257. Rurik, I.; Szigethy, E.; Langmár, Z. Medical Doctors in Hungary: 30 Years after Graduation. Data on Lifestyle, Morbidity, Demography and Differences between Specialties. Cent. Eur. J. Public Health 2014, 22, 183-188. [CrossRef]

258. Svärdsudd, K.; Wedel, H.; Gordh, T. Mortality Rates among Swedish Physicians: A Population-Based Nationwide Study with Special Reference to Anesthesiologists. Acta Anaesthesiol. Scand. 2002, 46, 1187-1195. [CrossRef] [PubMed]

259. Thomas, J.; Thomas, D.J.; Pearson, T.; Klag, M.; Mead, L. Cardiovascular Disease in African American and White Physicians: The Meharry Cohort and Meharry-Hopkins Cohort Studies. J. Health Care Poor Underserved 1997, 8, 270-283; discussion 284. [CrossRef]

260. Torre, D.M.; Wang, N.-Y.; Meoni, L.A.; Young, J.H.; Klag, M.J.; Ford, D.E. Suicide Compared to Other Causes of Mortality in Physicians. Suicide Life. Threat. Behav. 2005, 35, 146-153. [CrossRef] [PubMed]

261. Unal, S.; Tanriover, M.D.; Ascioglu, S.; Demirkazik, A.; Ertenli, I.; Eskioglu, E.; Guler, K.; Kiraz, S.; Ozbakkaloglu, M.; Ozer, B.; et al. Turkish Doctors' Cohort: Healthy despite Low Screening. Postgrad. Med. 2017, 129, 393-398. [CrossRef]

262. Mappin-Kasirer, B.; Pan, H.; Lewington, S.; Kizza, J.; Gray, R.; Clarke, R.; Peto, R. Tobacco Smoking and the Risk of Parkinson Disease: A 65-Year Follow-up of 30,000 Male British Doctors. Neurology 2020, 94, e2132-e2138. [CrossRef]

263. Glavas, D.; Rumboldt, M.; Rumboldt, Z. Smoking Cessation with Nicotine Replacement Therapy among Health Care Workers: Randomized Double-Blind Study. Croat. Med. J. 2003, 44, 219-224.

264. Saadat, H.; Snow, D.; Ottenheimer, S.; Dai, F.; Kain, Z. Wellness Program for Anesthesiology Residents: A Randomized, Controlled Trial. Acta Anaesthesiol. Scand. 2012, 56, 1130-1138. [CrossRef] [PubMed]

265. Goffette, C. Déterminants individuels et contextuels de la consommation de tabac. Rev. Fr. Sociol. 2016, 57, 213-239. [CrossRef]

266. Le Faou, A.-L. Tabac et Populations Défavorisées. Courr. Addict. 2002, 4, 10-14.

267. Dutheil, F.; Aubert, C.; Pereira, B.; Dambrun, M.; Moustafa, F.; Mermillod, M.; Baker, J.S.; Trousselard, M.; Lesage, F.-X.; Navel, V. Suicide among Physicians and Health-Care Workers: A Systematic Review and Meta-Analysis. PLoS ONE 2019, 14, e0226361. [CrossRef] [PubMed]

268. Dasagi, M.; Mantey, D.S.; Harrell, M.B.; Wilkinson, A.V. Self-Reported History of Intensity of Smoking Is Associated with Risk Factors for Suicide among High School Students. PLoS ONE 2021, 16, e0251099. [CrossRef]

269. Nabe-Nielsen, K.; Quist, H.G.; Garde, A.H.; Aust, B. Shiftwork and Changes in Health Behaviors. J. Occup. Environ. Med. 2011, 53, 1413-1417. [CrossRef]

270. Baggett, T.P.; McGlave, C.; Kruse, G.R.; Yaqubi, A.; Chang, Y.; Rigotti, N.A. SmokefreeTXT for Homeless Smokers: Pilot Randomized Controlled Trial. JMIR MHealth UHealth 2019, 7, e13162. [CrossRef]

271. Pinsker, E.A.; Hennrikus, D.J.; Erickson, D.J.; Call, K.T.; Forster, J.L.; Okuyemi, K.S. Trends in Self-Efficacy to Quit and Smoking Urges among Homeless Smokers Participating in a Smoking Cessation RCT. Addict. Behav. 2018, 78, 43-50. [CrossRef]

272. Dyrbye, L.N.; Thomas, M.R.; Shanafelt, T.D. Systematic Review of Depression, Anxiety, and Other Indicators of Psychological Distress among U.S. and Canadian Medical Students. Acad. Med. 2006, 81, 354-373. [CrossRef]

273. Masson, E. Alcoolisation à Risque Chez des étudiants en Médecine Parisiens. Available online: https://www.em-consulte.com/ article/1133310/alcoolisation-a-risque-chez-des-etudiants-en-medec (accessed on 6 June 2021).

274. Fond, G.; Bourbon, A.; Auquier, P.; Micoulaud-Franchi, J.-A.; Lançon, C.; Boyer, L. Venus and Mars on the Benches of the Faculty: Influence of Gender on Mental Health and Behavior of Medical Students. Results from the BOURBON National Study. J. Affect. Disord. 2018, 239, 146-151. [CrossRef]

275. Galleta-Williams, H.; Esmail, A.; Grigoroglou, C.; Zghebi, S.S.; Zhou, A.Y.; Hodkinson, A.; Panagioti, M. The Importance of Teamwork Climate for Preventing Burnout in UK General Practices. Eur. J. Public Health 2020, 30, iv36-iv38. [CrossRef]

276. Wu, A.W. Medical Error: The Second Victim. BMJ 2000, 320, 726-727. [CrossRef]

277. Garrabé, J. Le traumatisme du point de vue de la psychiatrie de la personne. J. Fr. Psychiatr. 2010, 36, 26. [CrossRef]

278. Galinowski, A. L'annonce du diagnostic en psychiatrie. Laennec 2011, 59, 44. [CrossRef]

279. Weill, A.; Vallier, N.; Salanave, B. La Fréquence Des 30 Affections de Longue Durée. Affect. Longue Durée 2007, 59, 18-29.

280. Deriaz, S.; Bridel, L. Profession médecin: Choix et perspectives selon le genre. Rev. Médicale Suisse 2010, 6, 1438-1442.

281. Goodman, J. Tobacco in History: The Cultures of Dependence; Reprinted; Routledge: London, UK, 1995; ISBN 978-0-415-11669-5.

282. Kirsch, M. Génèse d'une Épidémie. Lett. Collège Fr. 2010, 3, 5-14. [CrossRef]

283. Been, J.V.; Laverty, A.A.; Tsampi, A.; Filippidis, F.T. European Progress in Working towards a Tobacco-Free Generation. Eur. J. Pediatr. 2021, 180, 3423-3431. [CrossRef] [PubMed]

284. Commar, A.; Prasad, V.K.; Tursan d'Espaignet, E.; Wolfenden, L. WHO Global Report on Trends in Prevalence of Tobacco Smoking 2000-2025; World Health Organization: Geneva, Switzerland, 2018; ISBN 978-92-4-151417-0.

285. World Bank. Poverty and Shared Prosperity 2020: Reversals of Fortune; The World Bank: Washington, DC, USA, 2020; ISBN 978-1-4648-1602-4.

286. United Nations; Department of Economic and Social Affairs; Population Division. World Population Prospects Highlights, 2019 Revision Highlights, 2019 Revision; United Nations: New York, NY, USA, 2019; ISBN 978-92-1-148316-1.

287. Aubron, C.; Lehoux, H.; Lucas, C. Pauvreté et inégalités en Inde rurale. Réflexion à partir de deux diagnostics agraires dans l’État du Gujarat. EchoGéo 2015. [CrossRef]

288. Giovino, G.A.; Mirza, S.A.; Samet, J.M.; Gupta, P.C.; Jarvis, M.J.; Bhala, N.; Peto, R.; Zatonski, W.; Hsia, J.; Morton, J.; et al. Tobacco Use in 3 Billion Individuals from 16 Countries: An Analysis of Nationally Representative Cross-Sectional Household Surveys. Lancet 2012, 380, 668-679. [CrossRef] 
289. Health, A.G.D. Tobacco Control-Key Facts and Figures. Available online: https://www.health.gov.au/resources/publications/ tobacco-control-key-facts-and-figures (accessed on 25 June 2021).

290. Wilkinson, A.V. Smoking Prevalence Following Tobacco Tax Increases in Australia between 2001 and 2017: An Interrupted Time-Series Analysis-The Lancet Public Health. Lancet Public Health 2019, 4, e618-e627. [CrossRef]

291. Moodie, C.; Bauld, L.; Ford, A.; Mackintosh, A. Young Women Smokers' Response to Using Plain Cigarette Packaging: Qualitative Findings from a Naturalistic Study. BMC Public Health 2014, 14, 812. [CrossRef]

292. Brousse, G.; Zerhouni, O.; Perriot, J.; Bègue, L.; Flaudias, V. [Plain Packaging: The study that makes tabacologists coff]. L'Encephale 2018, 44, 489-490. [CrossRef]

293. Health, A.G.D. National Tobacco Campaign—Resources. Available online: https://www.health.gov.au/resources/collections/ national-tobacco-campaign-resources (accessed on 19 June 2021).

294. Prohibiting Smoking in Motor Vehicles Carrying Children under 18 Years of Age. Available online: https:/ / www.health.govt.nz/ about-ministry/information-releases / regulatory-impact-statements/prohibiting-smoking-motor-vehicles-carrying-childrenunder-18-years-age (accessed on 20 June 2021).

295. WHO. WHO Framework Convention on Tobacco Control; WHO: Geneva, Switzerland, 2005; ISBN 978-92-4-159101-0.

296. World No Tobacco Day. Available online: https:/ /www.euro.who.int/en/health-topics/disease-prevention/tobacco/world-notobacco-day (accessed on 6 June 2021).

297. Article R6152-27—Code de La Santé Publique-Légifrance. Available online: https:/ / www.legifrance.gouv.fr/codes/article_lc/ LEGIARTI000031304375/ (accessed on 31 May 2021).

298. Clavier, C.; Hassenteufel, P.; Fuentes, J.F.M.; Schweyer, F.-X. Les limites de la convergence du temps de travail des médecins hospitaliers en Europe (Allemagne, Danemark, Espagne, Lituanie, Royaume-Uni). Rev. Fr. Aff. Soc. 2011, 2, 226-251. [CrossRef]

299. Pallejà-Millán, M.; Rey-Reñones, C.; Barrera Uriarte, M.L.; Granado-Font, E.; Basora, J.; Flores-Mateo, G.; Duch, J. Evaluation of the Tobbstop Mobile App for Smoking Cessation: Cluster Randomized Controlled Clinical Trial. JMIR MHealth UHealth 2020, 8. [CrossRef]

300. Gram, I.T.; Larbi, D.; Wangberg, S.C. Comparing the Efficacy of an Identical, Tailored Smoking Cessation Intervention Delivered by Mobile Text Messaging Versus Email: Randomized Controlled Trial. JMIR MHealth UHealth 2019, 7, e12137. [CrossRef]

301. Rahman, M.A.; Hann, N.; Wilson, A.; Mnatzaganian, G.; Worrall-Carter, L. E-Cigarettes and Smoking Cessation: Evidence from a Systematic Review and Meta-Analysis. PLoS ONE 2015, 10, e0122544. [CrossRef]

302. Kushnir, V.; Sproule, B.A.; Cunningham, J.A. Impact of Large-Scale Distribution and Subsequent Use of Free Nicotine Patches on Primary Care Physician Interaction. BMC Public Health 2017, 18, 4. [CrossRef] [PubMed]

303. Prise en Charge des Substituts Nicotiniques. Available online: https://www.ameli.fr/assure/remboursements/rembourse/ medicaments-vaccins-dispositifs-medicaux / prise-charge-substituts-nicotiniques (accessed on 14 June 2021).

304. Nouvelle Campagne de Promotion de L'arrêt du Tabac: Et si 2021 était L'année où vous Arrêtez de Fumer? Available online: https: / / www.drogues.gouv.fr/actualites/nouvelle-campagne-de-promotion-de-larret-tabac-2021-etait-lannee-arretez-de-fumer (accessed on 14 June 2021).

305. Alla, F.; Berlin, I.; Nguyen-Thanh, V.; Guignard, R.; Pasquereau, A.; Quelet, S.; Schwarzinger, M.; Arwidson, P. Tobacco and COVID-19: A Crisis within a Crisis? Can. J. Public Health 2020, 111, 995-999. [CrossRef]

306. Clair, C. Genre et Disparités: L'exemple du Tabagisme. Rev. Med. Suisse 2015, 11, 1298-1303. [PubMed]

307. Pasquereau, A.; Andler, R.; Guignard, R.; Richard, J.-B.; Arwidson, P.; Nguyen-Thanh, V. La Consommation de Tabac En France: Premiers Résultats Du Baromètre Santé 2017. Sante Publique Fr. 2018, 14-15, 265-273.

308. Marques, C.; Quatremère, G. Les fumeurs français: Qui sont-ils? Résultats du baromètre de santé publique France. Bull. Epidémiologique Hebd. 2020, 14, 291-294.

309. Sun, M.; Jiang, Y.; Sun, C.; Li, J.; Guo, X.; Lv, Y.; Yu, Y.; Yao, Y.; Jin, L. The Associations between Smoking and Obesity in Northeast China: A Quantile Regression Analysis. Sci. Rep. 2019, 9, 3732. [CrossRef]

310. AL Reshidi, F.S. Level of Physical Activity of Physicians among Residency Training Program at Prince Sultan Military Medical City, Riyadh, KSA 2014. Int. J. Health Sci. 2016, 10, 39-47. [CrossRef]

311. Olson, S.M.; Odo, N.U.; Duran, A.M.; Pereira, A.G.; Mandel, J.H. Burnout and Physical Activity in Minnesota Internal Medicine Resident Physicians. J. Grad. Med. Educ. 2014, 6, 669-674. [CrossRef] [PubMed]

312. Ramsey, M.W.; Chen-Sankey, J.C.; Reese-Smith, J.; Choi, K. Association between Marital Status and Cigarette Smoking: Variation by Race and Ethnicity. Prev. Med. 2019, 119, 48-51. [CrossRef]

313. Saraç, F.; Öztekin, K.; Çelebi, G. Early Menopause Association with Employment, Smoking, Divorced Marital Status and Low Leptin Levels. Gynecol. Endocrinol. 2011, 27, 273-278. [CrossRef]

314. Lipinska, M. Histoire Des Femmes Médecins Depuis l'Antiquité Jusqu'à Nos Jours; Wentworth Press: Paris, France, 2018; ISBN 978-0-270-58649-7. 